Columbia Law School

Scholarship Archive

1981

\title{
The Survival of the Derivative Suit: An Evaluation and a Proposal for Legislative Reform
}

John C. Coffee Jr.

Columbia Law School, jcoffee@law.columbia.edu

Donald E. Schwartz

Follow this and additional works at: https://scholarship.law.columbia.edu/faculty_scholarship

Part of the Business Organizations Law Commons, and the Securities Law Commons

\section{Recommended Citation}

John C. Coffee Jr. \& Donald E. Schwartz, The Survival of the Derivative Suit: An Evaluation and a Proposal for Legislative Reform, 81 CoLUM. L. REV. 261 (1981).

Available at: https://scholarship.law.columbia.edu/faculty_scholarship/36

This Article is brought to you for free and open access by the Faculty Publications at Scholarship Archive. It has been accepted for inclusion in Faculty Scholarship by an authorized administrator of Scholarship Archive. For more information, please contact scholarshiparchive@law.columbia.edu. 


\title{
The Survival of the Derivative Suit: An Evaluation and a Proposal for Legislative Reform
}

\author{
John C. Coffee, Jr.* \\ Donald E. Schwartz**
}

The shareholder derivative suit today faces extinction. Long considered the "chief regulator of corporate management," ' and a recognized form of litigation in American courts at least since $1855,{ }^{2}$ it now confronts the second great challenge of its history. Thirty-odd years ago, commentators foresaw the derivative suit's demise when state legislatures began adopting security-for-expenses statutes to curb the abuses of "strike suit" litigation. ${ }^{3}$ These reports of its death proved exaggerated, however, as plaintiffs discovered various tactics by which to outflank these statutes. ${ }^{4}$ As a result, by the late 1960's, the crisis was past, and

* Visiting Professor of Law, Columbia Law School; Professor of Law, Georgetown University ' Law Center. B.A. 1966, Amherst College; LL.B. 1969, Yale; LL.M. (in taxation) 1976, N.Y.U.

** Professor of Law and Associate Dean, Georgetown University Law Center. A.B. 1952, Union; LL.B. 1955, Harvard; LL.M. (in taxation) 1966, N.Y.U.

We wish to acknowledge the very helpful assistance of Ellen Bromley, J.D. Candidate 1981, Georgetown University Law Center.

As this Article went to press, the Delaware Supreme Court reversed the decision in Maldonado v. Flynn, 413 A.2d 1251 (Del. Ch. 1980). The decision of the Delaware Supreme Court, Zapata Corp. v. Maldonado, No. 113, 1980 (Del. May 13, 1981) is discussed in a postscript to this Article.

1. Cohen v. Beneficial Indus. Loan Corp., 337 U.S. 541, 548 (1949).

2. The shareholder derivative suit is often said to have originated with Foss v. Harbottle, 67 Eng. Rep. 189, 2 Hare 461 (Ch. 1843). In America, the Supreme Court first recognized a stockholder's right to sue on behalf of his corporation in Dodge v. Woolsey, 59 U.S. (18 How.) 331 (1856). See also Prunty, The Shareholders' Derivative Suit: Notes on its Derivation, 32 N.Y.U. L. Rev. 980 (1957).

3. See, e.g., N.Y. Bus. Corp. Law $\S 627$ (Consol. Supp. 1979). This section was enacted pursuant to recommendations made by the Special Committee on Corporate Litigation of the Chamber of Commerce of the State of New York, Survey and Report Regarding Stockholder's Derivative Suits (1944) [hereinafter cited as Wood Report]. See Hornstein, The Death Knell of Stockholders' Derivative Suits in New York, 32 Calif. L. Rev. 123 (1944), for a stinging attack on the scholarship, accuracy, and objectivity of the Wood Report.

4. The principal such tactic has been to plead a federal cause of action. This is effective because the federal courts have held that Congress did not intend to subject claims arising under the Securities Exchange Act of 1934 to state security-for-expenses statutes. McClure v. Borne Chem. Co., 292 F.2d 824 (3d Cir. 1961), cert. denied, 368 U.S. 939 (1961) (\$ 10(b)); Borak v. J.1. Case Co., 317 F.2d 838 (7th Cir. 1963), aff'd, 377 U.S. 426 (1964). The requirement of security for expenses would still apply to a state claim jomed with the federal claim. See C. Wright \& A. Miller, Federal Practice \& Procedure: Civil $\S 1835$, at 408 (1972) for a brief discussion of security-forexpenses statutes, their history, and their success.

Various other techniques also exist by which to outflank the corporation's motion for security. See A. Frey, J. Choper, N. Leech \& C. Morris, Case and Materials on Corporations 705-06 (2d ed. 1977). The authors note that plaintiffs may overcome the obstacle these statutes present by such techniques as filing in states with no statute (such as Delaware), by finding other shareholders willing to intervene and thus boosting the number of shares to the amount necessary to sue without posting security, or by obtainimg stays to inspect company books in order to examine the shareholder list. In view of this last alternative, the corporation may decline to ask for security, since access to the list is likely to result in significant adverse publicity and consequent expense to the corporation. See Note, Security for Expenses in Shareholders' Derivative Suits: 23 Years' Experience, 4 Colum. J.L. \& Soc. Prob. 50, 62-65 (1968). 
a revival in the action's popularity was duly noted by leading academics. ${ }^{3}$

Today, the new threat is judicial, rather than legislative, and if the prophecies of doom are again to prove false, countervailing legislation may be necessary. In the aftermath of the Supreme Court's decision in Burks v. Lasker, ${ }^{6}$ a number of courts have upheld the capacity of disinterested directors, in the exercise of their business judgment, to terminate a derivative suit on the grounds that it is adverse to the corporation's best interests. As a practical consequence of this extension of the business judgment rule, a veto power over derivative actions may now rest with a corporation's often only nominally independent directors.

What has caused this transition? Curiously, no court has explicitly reevaluated the derivative suit, condemned it on policy grounds, cited any new consideration, or even reached any legal conclusion that could be described as original. Rather, the basic process has been a triumph of legal formalism: in theory, the derivative action asserts a corporate right, and hence, as a matter of formal logic, the right should be one that the board can waive or compromise. Such a conclusion has the force of logic, but not of experience. Realism suggests that an unqualified recognition of such a power may make the derivative suit an endangered species of legal action.

Not surprisingly, courts, when confronted with so significant an issue, have shrunk from its full implications. Thus, for the better part of this century, corporate law has recognized the simple axiom that a shareholder seeking to file a derivative suit must first exhaust available intracorporate remedies by making a demand on the corporation's board of directors, but never adequately explained the justification underlying this rule.' By itself, this demand rule is only a procedural hurdle, and in practice a fairly inconsequential one, that serves the legitimate purpose of giving the subject corporation an opportunity to take over the suit as its own or pursue internal remedies. However, if its underlying rationale is to give the directors an opportunity to reject the suit on the grounds that such a suit is in their judgment contrary to the best interests of the corporation, then the rule poses a more substantial, and substantive, obstacle-one that this Article will call the "standing requirement." 8

As a result of Santa Fe Indus., Inc. v. Green, 430 U.S. 462 (1977), the technique used in McClure v. Borne Chem. Co. is now less likely to succeed in assuring plaintiff a right to proceed with some claim in federal court. In Santa Fe Industries, the Supreme Court held that rule 10b-5 did not reach a simple breach of fiduciary duty absent deception. The consequence has been a trend toward curtailing federal-law involvement in corporate management affairs and reemphasizing state law. If the federal claim is dismissed for failure to state a cause of action, the court is likely to dismiss the pendent state claim for lack of jurisdiction. However, the other techniques available to discourage the demand for security may still prevent defendants from using their statutory right. See Note, supra.

5. Between 1956 and 1966 the number of reported derivative suits increased significantly over the previous decade, and the derivative suit was increasingly viewed as serving an important role in ensuring corporate accountability. Dykstra, The Revival of the Derivative Suit, $116 \mathrm{U}$. Pa. L. Rev. 74 (1967).

6. 441 U.S. 471 (1979).

7. See Note, The Demand and Standing Requirements in Stockholder Derivative Actions, 44 U. Chi. L. Rev. 168 (1976); and Note, Demand on Directors and Shareholders as a Prerequisite to a Derivative Suit, 73 Harv. L. Rev. 746 (1960). See also 3B Moore's Federal Practice § 23.1.19 (2d ed. 1975); Burks v. Lasker, 441 U.S. at 478-79.

8. "Standing" in the context of derivative actions is not to be confused with its more traditional function in limiting an individual's right to challenge governmental action. As used in the contcxt of 
Burks v. Lasker ${ }^{9}$ neither upheld nor rejected this standing requirement, holding rather that state law governs unless a federal policy would be frustrated by the imposition of a business judgment not to sue. Although the majority opinion in Burks conspicuously avoids any discussion of the prior common law surrounding the doctrine, ${ }^{10}$ subsequent decisions have treated Burks as removing any barrier to an expansive recognition of the defense. The New York Court of Appeals has probably gone the furthest in this direction, and in Auerbach v. Bennett " apparently held that the board's business judgment not to sue is beyond judicial inquiry, no matter how flawed its reasoning, except to the extent that the good faith or independence of those reaching the decision can be challenged. However, the scope of the standing requirement remains unclear even after Burks. Indeed, a much-noted Delaware decision, Maldonado v. Flynn (Maldonado II), ${ }^{12}$ wholly denied the board's capacity to terminate a derivative suit alleging selfdealing. Although the Delaware Supreme Court has recently reversed the case, its own decision (discussed in a postscript to this Article) seems also to be searching for a middle ground that will salvage the deterrent utility of derivative actions while curbing their potential for abuse.

Against this backdrop of still-unsettled law, this Article examines the standing requirement from both a historical and a policy perspective. Others have surveyed this terrain before us and with considerable skill. ${ }^{13}$ We differ from other commentators, however, in that our inquiry focuses on substantive, rather than procedural, limits on the defense, and on a legislative, rather than a judicial, response. Part I assesses the early cases before Burks and finds limitations implicit in them that Burks and its progeny have ignored. Part II looks at the developments since Burks and the possible boundaries on the defense that remain today. Of course, the conclusion that recent decisions have cantilevered a new doctrine upon a narrow foundation is in itself neither exciting nor necessarily important. The law's evolution has not infrequently proceeded on an overreading of precedent. Thus, Part III examines and compares the policy bases of the standing requirement and the business judgment rule generally. Finally, Part IV offers a legislative resolution. Because the issue of the board's authority to terminate derivative litigation intersects with related issues involving the procedural barriers to the prosecution of a derivative action, our focus expands in this final

derivative suits, the word has become a term of art, and denotes a requirement that minority shareholders must satisfy in order to sue despite the opposition of the board of directors. For a detailed discussion of the evolution of this concept see Note, The Demand and Standing Requirements in Stockholder Derivative Actions, 44 U. Chi. L. Rev. 168 (1976).

9. 441 U.S. 471 (1979).

10. The concurring opinion of Justices Stewart and Powell explicitly assumed that the common law had recognized such a defense. 1d. at 487 (Stewart, J., joined by Powell, J., concurring).

11. 47 N.Y.2d 619, 393 N.E.2d 994, 419 N.Y.S.2d 920 (1979).

12. 413 A.2d 1251, 1262 (Del. Ch., 1980), rev'd and remanded sub nom. Zapata Corp. v. Maldonado, No. 113, 1980 (Del. May 13, 1981).

13. Block \& Barton, The Business Judgment Rule as Applied to Stockholder Proxy Derivative Suits Under the Securities Exchange Act, 8 Sec. Reg. L.J. 99 (1980); Buxbaum, Conflict of lnterests Statutes and the Need for a Demand on Directors in Derivative Statutes, 68 Calif. L. Rev. 1122 (1980); Dent, The Power of Directors to Terminate Shareholder Litigation: the Death of the Derivative Suit?, 75 Nw. U.L. Rev. 96 (1980). Note, The Business Judgment Rule in Derivative Suits Against Directors, 65 Cornell L. Rev. 600 (1980). 
section, and the policy trade-offs that must underlie any integrated statutory provision for a model corporate statute are explored.

This undertaking has a premise that is best announced at the outset. Burks and the issucs it raises belong to a larger pattern. The concept of corporate accountability ultimately depends on some mechanism for its enforcement. Four principal remedies are potentially capable of holding corporate management accountable where shareholders are widely scattered and unorganizcd: the derivative suit; private causes of action (chiefly those under the federal securities laws); the proxy mechanism, under which shareholders can band together to defeat and possibly to depose the incumbent management; and the "market for corporate control," which, if management is incompetent or unfaithful, should in theory respond by discounting the corporation's shares so as to encourage a hostile takeover by those who believe they can restore value through better management. All these means have been substantially impaired during the last decade. In particular, the private cause of action has been radically pruned by the Supreme Court. ${ }^{14}$ Proxy fights are a rarity, and economists inform us that the utility of this approach to corporate accountability is dubious in theory as well as unproven in practice. ${ }^{15}$ Similarly, despite the current popularity of the tender offer, the disciplinary effect of such market-based remedies on managers remains suspect, particularly in the wake of defensive mergers and recent state antitakeover legislation. ${ }^{16}$ The transaction costs of the tender offer have skyrocketed, and some surveys have shown that the prospects for the defense in a contested tender offer have actually improved recently. ${ }^{17}$ As a consequence, Burks

14. The leading case involving implied private rights of action is Cort v. Ash, 422 U.S. 66 (1975), im which a unanimous Court denied a private right under the Federal Elcction Campaign Act. In two securities law cases, Blue Chip Stamps v. Manor Drug Stores, 421 U.S. 723 (1975), and Ernst \& Ernst v. Hochfelder, 425 U.S. 185 (1976), the Court expressed doubt as to the availability of an implied private right of action where an express remedy was available. More importantly, the Court has narrowed the test even further than the strict Cort tests. In Piper v. Chris-Craft lndus., Inc., 430 U.S. 1 (1977), the Court formulated a test that asks whether an implicd cause of action is necessary to effectuate the congressional goals. In Touche Ross \& Co. v. Redington, 442 U.S. 560 (1979), and Transamerica Mortgage Advisors, Inc. v. Lewis, 444 U.S. 11 (1979), the Court refined and narrowed the test, limiting it to whether Congress intended to crcate the private right of action asserted.

15. The standard critique of economists involves the "free rider" problem: no single shareholder will gratuitously undertake the expenses of orgarizing an opposition to the incumbent management, and no satisfactory mechanism exists for taxing all cqually. Sce M. Olson, The Logic of Collective Action 54-57 passim (1965).

16. A lively debate exists as to whether the tender offer results in the displacement of inefficient management. See Fischel, Efficient Capital Market Theory, the Market for Corporate Control, and the Regulation of Cash Tender Offers, 57 Tex. L. Rev. 1 (1978). The counter-view, widcly shared among market professionals, is that inefficient management will be relatively immune, rather than more vulnerable, to tender offers, because the bidder would prefer to acquire a sound company than one with significant problems. A recent survey by Touche Ross \& Co. of directors at large corporations found them in agreement that corporate bidders will no longer tender for "problem" companies, but will limit their attention to companies with "strong management." Touche Ross \& Co., The Effect of Mergers, Acquisitions, and Tender Offers on American Business: A Touche Ross Survey of Corporate Directors' Opinions 6, 11 (1981). State antitakeover statutes, while constitutionally suspect and frequently invalidated, may also shelter inefficient management. See Note, Securities Law and the Constitution: State Tender Offer Statutes Reconsidered, 88 Yale L.J. 510, 514 nn. $28 \& 29$ (1979) (listing 36 state statutes).

17. There has been a decline both in the number of tender offers and in the success of contested tender offers. Austin, Tender Offer Update: 1978-1979, Mergers and Acquisitions 13 (Summer 
raises the possibility of a right without a remedy, of an effectively unrestrained corporate management.

We do not claim, however, that the last outpost is necessarily about to fall. To date, relatively few state courts have had the opportunity to consider the standing issue that Burks thrusts upon them. ${ }^{18}$ The case law is therefore undeveloped, and although we believe legislation is desirable, the possibility remains for the development of a judicial definition of the standing requirement that permits the derivative suit to play a significant role in enforcing corporate accountability.

\section{The Standing Requirement: Early Cases}

The standing doctrine did not originate with Burks v. Lasker. As early as 1882 (only a quarter-century after it recognized the derivative suit), the Supreme Court had denied standing to shareholders who were otherwise procedurally eligible to sue, on the grounds that the board's refusal was a legitimate business judgment decision. ${ }^{19}$ The scope of this power remained ambiguous, however, and some decisions refused to recognize any such substantive power in the board once demand had been made. ${ }^{20}$ In any event, the doctrine appears to have been invoked on only a few occasions prior to the last five years. ${ }^{21}$

Modern-day proponents of a substantive standing doctrine often cite three Supreme Court decisions, decided between 1882 and 1917, as establishing that stockholders may not prosecute a derivative action over the board's objection unless they first demonstrate fraud or breach of trust on the part of their corporation's directors. This seems a casual and uncritical reading of precedent. These three cases-Hawes v. Oakland, ${ }^{22}$ Corbus v. Alaska Treadwell Gold Mining

1980). See also Lipton, Takeover Bids in the Target's Boardroom, 35 Bus. Law 101, 132 (1979), setting forth an impressive list of defeated tender offers. An empirical study has estimated that the Williams Act raised the cost of tender offers by between 13 and 27 percent. See Smiley, The Effect of the Williams Amendment and Other Factors on Transaction Costs in Tender Offers, 3 Indus. Organization Rev. 138, 145 (1975).

18. The few state cases to reach this issue are Sonics Int'l, Inc. v. Dorchester Enterprises, Inc., 593 S.W.2d 390 (Tex. Civ. App. 1980) (finding that derivative suit plaintiff had made a sufficient showing of standing to support a temporary injunction, despite an independent special litigation committee's decision not to prosecute the action); Maldonado v. Flynn, 413 A.2d 1251 (Del. Ch. 1980) (holding that once demand has been made and refused, a stockholder may assert his individual and the corporate rights together in a derivative suit), rev'd and remanded sub nom. Zapata Corp. v. Maldonado, No. 113, 1980 (Del. May 13, 1981); Auerbach v. Bennett, 47 N.Y.2d 619,393 N.E.2d 994, 419 N.Y.S.2d 920 (1979) (applying the business judgment doctrine to bar judicial inquiry into the determination of the special litigation committee that the corporation should not pursue the action, thus barring the derivative suit plaintiff from asserting the claim). In addition, the United States District Court for the Eastern District of Virginia, in a diversity case, applied Virginia law to deny a motion to dismiss, although an independent committee had determined that the best interests of the corporation would be served by dismissal. Abella v. Universal Leaf Tobacco Co., 495 F. Supp. 713 (E.D. Va. 1980).

19. Hawes v. City of Oakland, 104 U.S. 450,462 (1882) (water company decision to furnish water to city free of charge).

20. See Dent, supra note 13 , at 100 n. 25 .

21. But see, e.g., United Copper Sec. Co. v. Amalgamated Copper Co., 244 U.S. 261, 263 (1917); Corbus v. Alaska Treadwell Gold Mining Co., 187 U.S. 455, 463 (1903); Ash v. IBM, Inc., 353 F.2d 491 (3d Cir. 1965), cert. denied, 384 U.S. 927 (1966); Swanson v. Traer, 249 F.2d 854, 857 (7th Cir. 1957); Issner v. Aldrich, 254 F. Supp. 696 (D. Del. 1966).

22. 104 U.S. 450 (1882). 
Co. ${ }^{23}$ and United Copper Sec. Co. v. Amalgamated Copper Co ${ }^{24}$-shared a critical common fact: all involved "third party" litigation. The plaintiff shareholder wished the corporation to sue an entirely separate and unaffiliated entity, and the board of directors was not subject to even a colorable conflict of interests in any of the cases. This basic point was not overlooked. Writing for the Court in United Copper, Justice Brandeis noted:

In the instant case there is no allegation that the United Copper Company is in the control of the alleged wrongdoers or that its directors stand in any relations to them or that they have been guilty of any misconduct whatsoever. Nor is there even an allegation that their action in refusing to bring such suit is unwise. ${ }^{25}$

The special historical context of these cases also limits the breadth of their holdings. They were a reaction to a collusive practice in which the Court had previously acquiesced, but which, by the 1880's, had lost any possible justification. Before this period, the federal courts had no general federal question jurisdiction, and derivative suits were used collusively to create diversity of citizenship, thereby enabling federal courts to hear cases otherwise outside their jurisdiction. The first Supreme Court decision recognizing the derivative suitDodge $v$. Woolsey ${ }^{26}$ in 1855 -reveals the basic pattern. A Connecticut stockholder sued an Ohio corporation to enjoin it from paying an allegedly unconstitutional tax to the state of Ohio. This procedural contrivance of using a non-Ohio shareholder to sue both his corporation and the true party in interest (the tax collector) enabled the corporation to place the question of the tax's constitutionality before a federal trial court. The Supreme Court sustained the practice over the objection of the Ohio tax collector, who understood what was occurring and argued that plaintiff lacked standing. Such manufactured federal jurisdiction persisted until 1882, when the Court noted, in Hawes v. Oakland, that the growth of corporate litigation since Dodge had overburdened it and required reconsideration of that decision. ${ }^{27}$ Meanwhile, federal question jurisdiction had been generally established in $1875,{ }^{28}$ and there was no longer a need for such a dubious device. Hawes thus seems more a policy-motivated decision seeking to curb a disreputable form of litigation than a pillar for the standing requirement. ${ }^{29}$

An additional problem with using the Hawes-Corbus-United Copper trilogy as the foundation for a pervasive standing requirement is raised by Ashwander $v$.

23. 187 U.S. 455 (1903).

24. 244 U.S. 261 (1917).

25. Id. at 264 .

26. 59 U.S. (18 How.) 331 (1855). 297-99.

27. 104 U.S. at 452-57. See also 7A C. Wright and A. Miller, supra note 4, § 1821, at (1976)).

28. Act of March 3, 1875, c. $137, \S$ I, 18 Stat. 470 (eurrent version at 28 U.S.C. $\S 1331$

29. In this respeet, Hawes is analogous to Blue Chip Stamps v. Manor Drug Stores, 421 U.S. 723 (1975), which sought to reduce the volume of securitics litigation under rule 10b-5, perceived as frequently extortionate. Id. at 737-49. 
Tennessee Valley Authority. ${ }^{30}$ In Ashwander, the Supreme Court upheld the right of a plaintiff stockholder to conscript his corporation in order to sue a third party (the T.V.A.) despite the objections of the corporation's board of directors. Ashwander is thus factually identical with Hawes and Corbus (in each of which the plaintiff also sought to oppose governmental action). Justice Brandeis's concurrence in Ashwander (which simply reiterated the position he had earlier taken in United Copper) is often cited as authority for the business judgment discretion of directors to refuse to sue. ${ }^{31}$ But the plurality opinion reached almost the opposite conclusion:

In such a case it is not necessary for stockholders-when their corporation refuses to take suitable measures for its protection-to show that the managing board or trustees have acted with fraudulent intent or under legal duress. To entitle the complainants to equitable relief, in the absence of an adequate legal remedy, it is enough for them to show the breach of trust or duty involved in the injurious and illegal action. . . . Thus, the breach of duty may consist in yielding, without appropriate resistance, to governmental demands which are without warrant of law or are in violation of constitutional restrictions. ${ }^{32}$

Attempts have been made to limit Ashwander to cases involving illegal governmental action. ${ }^{33}$ This distinction, however, is questionable. As a matter of precedent, both Corbus and Hawes involved similar claims. As a matter of logic, the asserted distinction is even more dubious, because a board decision not to resist governmental pressure seems inherently less suspect than most other decisions. Given the resources at the disposal of the government and the potential for future retaliation by it, a decision by management not to challenge the government would appear at least presumptively justified. In contrast to a case involving an intracorporate dispute, there is not even a latent conflict of interests; instead, there is the foreboding possibility that a victory against the government, in a suit that a single-share plaintiff forces the corporation to bring, could prove a Pyrrhic one.

Although Ashwander might be read as a repudiation of the Hawes-CorbusUnited Copper trilogy, the Supreme Court's subsequent decision in Swanson $v$. Traer $^{34}$ clouds the issue and suggests that Ashwander is probably an aberration,

30. 297 U.S. 288 (1936). See also Rogers v. American Can Co., 305 F.2d 297, 309, 317 (3d Cir. 1962) (majority vote by shareholders to reject suit ineffective where complaint alleges actions that "are ultra vires the corporation and are public wrongs."); cf. Gottesman v. General Motors Corp., 268 F.2d 194, 197 (2d Cir. 1959) (demand on board unnecessary where complaint charges illegal acts).

31. See, e.g., Gall v. Exxon Corp., 418 F. Supp. 508, 519 (S.D.N.Y. 1976).

32. Ashwander v. Tennessee Valley Auth., 297 U.S. at 319.

33. In Klotz v. Consolidated Edison Co., 386 F. Supp. 577, 583 (S.D.N.Y. 1974), the court distinguished Ashwander narrowly: "In Ashwander, the actions of the TVA were not attacked as unreasonable. Rather the stockholders challenged the authority's right to act at all." In Klotz, plaintiff challenged the Public Service Commission's determination of the particular rate, not its right to set rates. Such a distinction seems tenuous, but probably reflects a prevalent judicial desire to treat Ashwander's plurality opinion as an aberrant case.

34. 354 U.S. 114 (1957). 
better explained by the desire of the plurality to reach the constitutional issue surrounding the T.V.A. than by an intent to establish standards for derivative suit litigation. In Swanson v. Traer, the Supreme Court remanded a derivative action to the Seventh Circuit with instructions to determine whether under state law the action was of "that exceptional character which stockholders may bring." 35 Although the use of the adjective "exceptional" seems a gratuitously didactic instruction to the lower court, the decision as a whole is consistent with the teaching of Erie Railroad v. Tompkins ${ }^{36}$ that state law should control. Thus, although its tone suggests a preference for the standing doctrine, its real holding is that state law, rather than the Hawes-Corbus-United Copper trilogy, controls.

In Swanson, defendants were alleged to have bought certain bus lines and resold them to their corporation at an inflated price. Thus, it is the only Supreine Court decision prior to Burks that involved self-dealing. But, like Ashwander, it may show the Court interpreting the standing requirement in the light of ulterior motives. As decided below, Swanson raised a difficult issue that the Court found more convenient to resolve in a companion case: whether the corporation should be aligned as a plaintiff or as a defendant. ${ }^{37}$ If it were classified as the former, diversity would be destroyed. Finding this issue more clear cut in the companion case, ${ }^{38}$ the Supreme Court turned instead in Swanson to the standing question, which permitted it to wash its hands of the case by remanding for a determination of Illinois law. ${ }^{39}$ On remand, the Seventh Circuit found that where the majority of the board that approved the transaction was not subject to any conflict of interest or obvious domination, its decision not to sue would be respected. ${ }^{40}$ Thus, not only can Swanson be read as only a circuit court holding on the nature of the Illinois standing requirement, but there is also at least a hint that the Supreme Court was only adhering to the "passive virtues" and avoiding a possibly unripe issue when it remanded to the Seventh Circuit. At the circuit court level, Swanson is concededly an exception to the pattern of earlier cases in which the standing requirement proved a barrier only where the defendants were all third parties. Equally important, however, it is an exception involving a board a majority of whose members were not subject to the conflict, and thus it does not logically reach the more recent fact pattern of a board, a majority of whose members are defendants, that expands its size, elects new directors, and appoints them to a special litigation committee..$^{41}$

35. Id. at 116.

36. 304 U.S. 64 (1938).

37. See Swanson v. Traer, 230 F.2d 228, 235-38 (7th Cir. 1956), rev'd, 354 U.S. 114 (1957).

38. See Smith v. Sperling, 354 U.S. 91 (1957).

39. Swanson v. Traer, 354 U.S. at 117.

40. Swanson v. Traer, 249 F.2d 854, 856 (7th Cir. 1957).

41. Similarly, in Issner v. Aldrich, 254 F. Supp. 696 (D. Del. 1966), the court noted that only three of seventeen directors were affiliated with the parent corporation, and therefore accepted the board's decision to reject the suit.

More recently, some courts have accepted decisions by "special litigation committees" composed of only three directors, appointed io the board after initiation of the suit. See Maldonado v. Flynn (Maldonado I), 485 F. Supp. 274, 278 (S.D.N.Y. 1980); Rosengarten v. International Tel. \& Tel. Corp., 466 F. Supp. 817, 821 (S.D.N.Y. 1979); Auerbach v. Bennett, 47 N.Y.2d 619, 625, 
The circuit court cases on the standing requirement that immediately followed Swanson basically continued to be those involving third-party litigation. In Stadin v. Union Electric Co. ${ }^{42}$ the derivative suit was commenced by a plaintiff who wished Union Electric to sue Westinghouse for antitrust damages. But Union Electric had already brought such a suit, and the issue thus reduced to who would control the litigation. In $A s h v . I B M,^{43}$ the plaintiff shareholders of three corporations tried to force the corporations to seek to enjoin the acquisition of a fourth corporation by a fifth on antitrust grounds. The denial of standing in these cases should not be surprising. In neither case was there any indication of a conflict of interest. Moreover, in Union Electric the desired suit had already been commenced, and in Ash the benefits of the litigation, even if successful, seemed very speculative. ${ }^{44}$

Concededly, cases involving third-party litigation can supply no more than a negative inference. They cannot tell us what the reaction of courts prior to Burks would have been to a termination decision where plaintiff alleged self-dealing by management. Relatively few cases have dealt with such a decision. But in several of those that have, courts either have declined to accept decisions of the board that would have terminated derivative litigation or have skirted the issue by declining to grant the requested motion for summary judgment on other grounds.

The first approach is illustrated by Groel $v$. United Electric Co. ${ }^{45}$ There, the board had declined to pursue a claim for watered stock against the corporation's promoters. The corporation stood to recover $\$ 20,000,000$ of stock. In response to the asserted business judgment that it was undesirable to sue, the court held that under the circumstances, "if the complainant sets forth a good cause of action, ... it is a clear breach of trust on the part of the directors not to proceed to recover the same." ${ }^{46}$ The court further observed that "for [the directors] to reply that it is by them deemed inexpedient to do so is only to emphasize the breach of trust they are committing by not doing so." 47 Thus, if the complaint appears to plead a meritorious cause of action, there is no discretion to reject it. ${ }^{48}$ This is concededly the minority rule; only a few cases clearly hold that the shareholder is automatically entitled to sue once the board rejects his demand. ${ }^{49}$

393 N.E.2d 994, 997, 419 N.Y.S.2d 920, 923 (1979). These decisions are in our judgment without persuasive precedent and invite the use of "tame" special litigation committees. Accordingly, our proposed statute requires that a majority of the board be independent before the defense can be interposed. See $\$ 49(f)$ in Appendix infra.

42. 309 F.2d 912 (8th Cir. 1962), cert. denied, 373 U.S. 915 (1963).

43. 353 F.2d 491 (3d Cir. 1965), cert. denied, 384 U.S. 927 (1966).

44. At least one commentator has cited Ash, Swanson, and Union Electric for the proposition that "absent unusual circumstances, [the directors'] decision not to sue will be final." Note, The Demand and Standing Requirements in Stockholder Derivative Actions, 44 U. Chi. L. Rev. 168, 192 (1976) (footuote omitted). This seems overbroad, since at least two of these cases involve the relatively "unusual" circumstance of third-party litigation.

45. 70 N.J. Eq. 616,61 A. 1061 (Ch. 1905).

46. Id. at $624,61 \mathrm{~A}$. at 1064 .

47. Id.

48. This position is close to that of the Delaware court in Maldonado v. Flynn (Maldonado II), 413 A.2d 1251, 1262 (Del. Ch. 1980). See text accompanying notes 77-81 infra.

49. In addition to Maldonado II and Groel v. United Elec. Co., the following cases indicate that a substantive standing requirement is undesirable: Papilsky v. Bemdi, 503 F.2d 554, 556 (2d 
A second judicial reaction is to permit the case to go forward (at least until a judicial examination of the merits is reached) and simply to avoid engaging the substantive question of the board's capacity to reject the suit. Again, this reaction is most discernible in cases involving alleged self-dealing.

Fleishhacker v. Blum ${ }^{50}$ well illustrates this pattern. There, the board refused to sue after demand had been made in a case involving a bank president who received side payments for his approval of bank loans. The majority opinion for the Ninth Circuit barely discusses this rejection, stating only that "all the circumstances of the case" made it unjustified. ${ }^{51}$ But a detailed dissent, which elaborately restates the prior case law upholding such refusals to sue, shows that the majority must have been aware of the Supreme Court's trilogy of opinions. ${ }^{52}$ Thus, the decision indicates at least that such a refusal may be rejected by the court even in the absence of any showing of bad faith.

Arguably, Fleishhacker and similar cases ${ }^{33}$ show that where the challenged transaction contains aspects of self-dealing, the court will sub silentio impose a higher standard of judicial review, even though the directors themselves were not dominated or controlled by the defendants. A more recent case refused defendant's motion for summary judgment where an alleged "sweetheart" sale of securities was involved, even though the complaint failed to allege that the wrongdoers had control of the board. ${ }^{54}$ In contrast to Groel, these decisions

Cir.) (per curiam), cert. denied, 419 U.S. 1048 (1974); Sohland v. Baker, 141 A. 277, 282 (Del. Sup. Ct. 1927); Anderson v. Johnson, 45 R.I. 17, 23, 119 A. 642, 644 (1923); Bergman Clay Mfg. Co. v. Bergman, 73 Wash. 144, 151, 131 P. 485, 488 (1913).

An intermediate position is to distinguish particular classes of claims-typically those involving illegality or "nonratifiable" wrongs - which plaintiff may seek to redress, regardless of rejection by the board or shareholders. See Rogers v. American Can Co., 305 F.2d 297, 309, 317 (3d Cir. 1962); Shaw v. Staight, 107 Minn. 152, 160-61, I19 N.W. 951, 954-55 (1909); Sullivan v. Mountain, 117 Mont. 224, 228-29, 160 P.2d 477, 479-80 (1945); Siegman v. Kissel, 71 N.J. Eq. 123, 125-27, 62 A. 941, $941-42$ (Ch. 1906), aff'd sub. nom Siegman v. Electric Vehicle Co., 72 N.J. Eq. 403, 409-10, 65 A. 910, 912-13 (Ct. Err. \& App. 1907); Epstein v. Schenck, 35 N.Y.S.2d 969, 981-82 (Sup. Ct. 1939); Note, Demand on Directors and Shareholders as a Prerequisite to a Derivative Suit, 73 Harv. L. Rev. 746, 762 (1960); cf. Klotz v. Consolidated Edison Co., 386 F. Supp. 577, 581-84 (S.D.N.Y. 1974) (challenge to constitutionality of a regulatory statute).

Still other cases have rejected the necessity of demand in cases involving alleged illegal behavior by corporate officials, thereby tacitly holding that a hoard decision to rejeet the suit would not be accepted by the court in such circumstances. See Gottesman v. General Motors Corp., 268 F.2d 194, 197 (2d Cir. 1959); Continental Sec. Co. v. Belmont, 206 N.Y. 7, 16-19, 99 N.E. 138, 141-42 (1912).

50. 109 F.2d 543 (9th Cir. 1940).

51. Id., at 547 .

52. Id. at 551 (noting absence of any proof of bad faith as to board's determination not to sue).

53. See Fogelson v. American Woolen Co., 170 F.2d 660, 662-63 (2d Cir. 1948); Cooper v. Central Alloy Steel Corp., 43 Ohio App. 455, 471-72, 183 N.E. 439, 445 (1931). In Fogelson, the plaintiffs challenged the propriety of a pension plan, and the directors (who included a former Governor of Massachusetts and several other respected public figures, see Bernstein v. Mediobanca Banca di Crcdito Finanziario-Societa Per Azioni, 69 F.R.D. 592, 597 (S.D.N.Y. 1974)) responded with affidavits asserting that the pension plan was a decision within their business judgment. Although these affidavits were uncontested, the Second Circuit reversed the grant of summary judgment for defendants, holding that such a showing was too conclusory and could not alone support a motion for summary judgment on the business judgment defense. 170 F.2d 663 . Yet the showing made by defendants was at least as strong as that made in many of the third party cases in which it was accepted as dispositive. See also Sonics Int'l, Inc. v. Dorchester Enterprises, Inc., 593 S.W.2d 390 (Tex. Civ. App. 1980).

54. Bernstein v. Mediobanca Banca di Credito Finanziario-Societa Per Azioni, 69 F.R.D. 592, 597-98 (S.D.N.Y. 1974) (citing Fogelson v. American Woolen Co., 170 F.2d 660 (2d Cir. 1948)). 
may accept the principle of the Hawes-Corbus-United Copper trilogy as applying beyond the third-party context; but at least in self-dealing cases they show courts exercising careful oversight and requiring persuasive justifications.

It seems a fair summary of the decisions before Burks that, although they recognized the business judgment discretion of the board to terminate a derivative action, they applied that principle to bar such a suit almost exclusively in the context of third-party litigation and rarely in circumstances that suggested the board had acquiesced in a self-dealing transaction. Exceptions-and concededly there are pieces that do not quite fit this jigsaw puzzle ${ }^{55}$ - tend to involve "ordinary" business decisions (such as compensation) rather than structural changes or intracorporate dealings.

\section{Burks AND ITS PROGENY}

1n a recent case upholding a board's decision to terminate a derivative action the Ninth Circuit asserted that in so dismissing the suit it was following "a clear trend in corporate law." $\$ 6$ This may yet prove an accurate prophecy, but for the present it still seems an alarming overstatement. Again, as in the decisions before Burks, the recent cases have a hidden common denominator: where once it was the third-party character of the actions, today it is their outgrowth from "questionable payments" investigations. Almost all have involved attempts to hold corporate officials liable for improper payments made typically on behalf of the corporation and usually in a context where such payments were historically accepted. ${ }^{37}$ This is said not to justify such payments, but to caution against overgeneralization based on essentially one recurring example.

Unmistakably, the pivotal decision in the revival of the standing defense was Gall v. Exxon,,$^{58}$ a 1976 district court case dealing with the allegedly negligent failure of Exxon executives to detect and report the use of corporate moneys for political purposes in ltaly. In its rhetoric, Gall said little that had not

55. E.g., Beard v. Elster, 160 A.2d 731 (Del. 1960), on remand sub nom. Elster v. American Airlines, Inc., 39 Del. Ch. 476, 167 A.2d 231 (1961). In this case the Delaware Supreme Court held that where a disinterested Board of Directors had adopted an option plan designed to secure the retention of key employees' services, the plan was valid and summary judgment would be entered for the defendant-directors in the derivative suit challenging the plan. The application of the business judgment rule was arguably less objectionable in such a case, because the facts involved only a normal compensation plan, which fell within the scope of routine board decision-making. Swanson $v$. Traer, 249 F.2d 854 (7th Cir. 1957), is also an exception; it would be reversed under our statute if the defendants constituted "controlling persons." See Appendix, infra.

56. Lewis v. Anderson, 615 F.2d 778, 783 (9th Cir. 1979) (applying California law), cert. denied, 101 S. Ct. 206 (1980).

57. See Abbey v. Control Data Corp., 603 F.2d 724 (8th Cir. 1979), cert. denied, 444 U.S. 1017 (1980); Rosengarten v. Interntional Tel. \& Tel. Corp., 466 F. Supp. 817 (S.D.N.Y. 1979); Gall v. Exxon Corp., 418 F. Supp. 508 (S.D.N.Y. 1976); Auerbach v. Bennett, 47 N.Y.2d 619, 393 N.E.2d 994, 419 N.Y.S.2d 920 (1979); Parkoff v. General Tel. \& Elec. Corp., 74 A.D.2d 762, 425 N.Y.S.2d 599 (1980); Wechsler v. Exxon Corp., 55 A.D.2d 875, 390 N.Y.S.2d 111 (1977); Falkenberg v. Baldwin, N.Y.L.J., Mar. 3, 1980, at 12, col. 6 (Sup. Ct. 1980); Auerbach v. Aldrich, N.Y.L.J., Dec. 23, 1977, at 13, col. 5 (Sup. Ct. 1977); Levy v. Sterling Drug, Inc., N.Y.L.J., Nov. 23, 1977, at 10, col. 3 (Sup. Ct. 1977).

58. 418 F. Supp. 508 (S.D.N.Y. 1976). 
been said before; its significance lay rather in the judicial blessing it gave to a new defense tactic, the special litigation committee. Gall showed this technique raised to the level of a formalized methodology: step one, the Board appoints a special litigation committee and delegates decision-making authority concerning the lawsuit to it; step two, the committee retains distinguished special counsel, preferably a retired judge; step three, a lengthy study and report is prepared, which casts doubt on the strength of plaintiff's case; and step four, the committee reaches the final decision not to sue, based on the report and the opinion of special counsel that litigation would not be in the best interests of the corporation.

Gall, however, never clearly addressed the question whether state or federal law governs termination by directors. This question was "resolved" by Burks $v$. Lasker ${ }^{59}$-although Burks probably raises more ambiguities than it clarifies. Burks involved a derivative suit by shareholders of a mutual fund against several directors of the fund and its investment adviser. Plaintiffs alleged violations of the Investment Company Act of $1940^{60}$ and the 1nvestment Advisers Act of $1940,{ }^{61}$ centering around the fund's substantial purchases of the commercial paper of Penn Central just prior to the insolvency of that corporation. No selfdealing was alleged on the part of defendants; rather, plaintiffs charged that defendants, in relying almost exclusively upon the advice of a third-party brokerage firm, had failed to exercise due care. After the derivative suit was commenced, the fund's independent directors decided that the litigation was adverse to the fund's interests and moved to dismiss. The trial court granted their motion, ${ }^{62}$ but the Second Circuit reversed, holding that the lnvestment Company Act precluded such a decision. ${ }^{63}$ Rejecting the Second Circuit's broad theory, the Supreme Court instead employed a two-tiered analysis. First, it held that federal law, although governing, does not displace state law, but incorporates it ${ }^{64}$ so that ultimately state law governs whether disinterested directors possess the power to terminate a derivative suit. Second, the Court acknowledged that even if state law permitted such a decision, there could be circumstances in which such a state policy was inconsistent with a federal policy underlying the cause of action, in which case termination would not be allowed. Finding no such conflict with policies of either federal statute, it remanded for a determination as to New York law on the board's power to terminate. ${ }^{\text {ss }}$

Although Burks thus deferred to state law, theoretically permitting disparate results, subsequent decisions have seen it as a reaffirmation of the old pre-Erie

59. 441 U.S. 471 (1979).

60. 15 U.S.C. $\S \S 80 \mathrm{a}-1$ to $80 \mathrm{a}-52$ (1976).

61. 15 U.S.C. $\S \S 80 \mathrm{~b}-1$ to $80 \mathrm{~b}-20$ (1976).

62. Lasker v. Burks, 426 F. Supp. 844, 853 (S.D.N.Y. 1977), rev'd, 567 F.2d 1208 (2nd Cir. 1978), rev'd, 441 U.S. 471 (1979).

63. Lasker v. Burks, 567 F.2d 1208, 1209 (2nd Cir. 1978), rev'd, 441 U.S. 471 (1979).

64. Burks v. Lasker, 441 U.S. at 477-78.

65. In their concurring opinion, Justices Stewart and Powell characterized the decision to sue (or not to) as an ordinary one made in accordance with state law, and incapable of eonflicting with the federal law in question. Id. at 487. On the other hand, Justiee Blackmun, in a separate concurrence, found this position "absolutist." In his view, the task on reenand was to explore whether a confliet with federal policy existed. Id. at 486. 
trilogy of Hawes, Corbus, and United Copper.$^{66}$ This is curious because the majority opinion in Burks never discusses these decisions. ${ }^{67}$

Standing alone, Gall and Burks would not resolve the issue of whether the so-called business judgment defense extends to a self-dealing case. As discussed above, early cases had generally honored the board's decision not to sue only in the context of third-party litigation. ${ }^{68}$ Burks and Gall suggest that the defense now will also cover alleged failures in the duty to supervise-or, more broadly, the duty of due care. The critical question, however, still remains: do Burks and Gall describe the outer perimeters of the defense, or are they only half-way points on a slippery slope that leads to a bottom at which the defense can be raised in self-dealing cases as well? In the wake of Burks several decisions have faced this question and others that the prior case law has never clearly resolved.

\section{A. Self-Dealing Transactions}

The Maldonado litigation graphically shows the degree of uncertainty that still persists around the business judgment rule. Within the space of two months in 1980, a distinguished federal judge and a Vice Chancellor of Delaware reached diametrically opposite conclusions on whether Delaware law permits the board to deny the plaintiff-shareholder standing in a self-dealing case. In the federal decision (Maldonado I), ${ }^{69}$ Judge Weinfeld dismissed the case, apparently finding no difference between a self-dealing case and the earlier due care decisions. Subequently, in the parallel state case (Maldonado $I I){ }^{70}$ the court refused to dismiss. Declining narrower grounds on which to distinguish the case, it held broadly that the decision not to sue is so fundamentally different from the kind of discretion the business judgment rule was intended to protect that it does not fall within the protection of that rule.

The facts underlying the Maldonado cases pivot around stock options issued by the Zapata Corporation to its officers and directors. ${ }^{n}$ As the date of exercise for these options approached, Zapata decided for independent reasons to make a tender offer for its own shares, which would have the effect of raising the price of the corporation's stock from $\$ 18$ to $\$ 25$ per share. This increase in market value meant that additional federal income tax liability would have resulted for those exercising the option subsequent to the tender offer, because the gain would have been measured for tax purposes by the difference between exercise

66. United Copper Sec. Co. v. Amalgamated Copper Co., 244 U.S. 261 (1917); Corbus v. Alaska Treadwell Gold Mining Co., 187 U.S. 455 (1903); Hawes v. Oakland, 104 U.S. 450 (1882). For a post-Burks decision that continues to cite these cases as authoritative, see Abbey v. Control Data Corp., 603 F.2d 724, (8th Cir. 1979), cert. denied, 444 U.S. 1017 (1980).

67. United Copper, however, is cited in Justice Stewart's concurring opinion, Burks v. Lasker, 441 U.S. at 487. It is also included in a string citation in the majority opinion, but only for the proposition that Congress did not intend to displace "the entire corpus of state corporation law ... simply because a plaintiff's action is to be based upon a federal statute." Id. at 478.

68. See text accompanying notes $22-30$ supra.

69. Maldonado v. Flynn, 485 F. Supp. 274 (S.D.N.Y. 1980).

70. Maldonado v. Flynn, 413 A.2d 1251 (Del. Ch. 1980), rev'd and remanded sub nom. Zapata Corp. v. Maldonado, No. 113, 1980 (Del. May I3, 1981).

71. See id. at 1254-55. 
price and then-current market value. To reduce the individual income tax liability, the directors voted to accelerate the date on which the options could be exercised to a time before the announcement of the tender offer. However, this reduced not only the individual tax liability, but the corporation's corresponding tax deduction as well. ${ }^{2}$

Derivative suits were filed in state and federal courts. ${ }^{31}$ ln the Delaware Chancery Court, the plaintiff alleged a breach of fiduciary duty by directors who put their interest in reduced taxes above the corporation's interest in a higher tax deduction. In federal court, plaintiff's amended complaint asserted federal proxy rule violations in connection with the reelection of the directors who had so benefited. Four years after the filing of these suits, the Zapata board appointed two new directors and constituted them the "Independent Investigation Committee of Zapata Corporation." Within three months of their appointment, they filed a "Report and Determination" to the effect that the lawsuits that had been filed with respect to the amendment of the stock option plan should be dismissed. At their direction, the corporation's counsel moved for dismissal.

Delaware had no precedent directly dealing with a board decision not to sue. Nevertheless, Judge Weinfeld, in the federal action, concluded that the wealth of Delaware case law upholding the business judgment discretion of directors implied that the board of a Delaware corporation had authority to terminate derivative litigation. ${ }^{74}$ Although he ruled that this authority could be exercised only by disinterested directors, properly vested with the powers of the board, ${ }^{75}$ Judge Weinfeld drew no distinction between self-dealing and other forms of fiduciary breach, or between fiduciary breaches generally and thirdparty law suits. Instead, he focused primarily on whether the decision would frustrate the federal policy underlying the proxy rules. He declined to find that it would, basically because he believed the policy of the federal proxy rules could be enforced by means other than a derivative suit. ${ }^{76}$

The Delaware court saw the issue quite differently, but equally broadly. It also gave little attention to the difference between self-dealing cases and cases involving only a breach of the duty of due care. Rather, it distinguished the "business judgment" decision not to sue from the traditional "business judgment rule," noting that the policies underlying the latter do not extend to the former." The court drew three principal distinctions. First, it construed the

72. The corporation would be able to deduct only $\$ 18$ a share, although the price would appreciate, on announcement of the offer, to $\$ 25$.

73. A third action was commenced in federal court in Houston, Texas, by a different plaintiff, who alleged the same facts and other grievances as well. Maher v. Zapata Corp., 490 F. Supp. 348 (S.D. Tex. 1980).

74. Maldonado v. Flynn, 485 F. Supp. at 278-79 (citing Abbey v. Control Data Corp., 603 F.2d 724 (8th Cir. 1979), cert. denied, 444 U.S. 1017 (1980)). In Abbey the court examined relevant Delaware law and inferred that the business judgment rule would apply to any reasonable good-faith determination by an independent board stating that a derivative action is not in the corporation's best interest.

75. Maldonado v. Flynn, 485 F. Supp. at 279-80.

76. Id. at 281 .

77. Maldonado v. Flynn, 413 A.2d at 1257. 
business judgment rule as essentially a rebuttable presumption of propriety of directors' decisions - a defensive procedural rule that requires the court to find for the directors and officers of a corporation unless a plaintiff can show by specific evidence that the challenged decision was the product of "fraudulent, illegal, or reckless decisions by the directors." 78 Under this view, the business judgment rule is irrelevant to the question of whether the suit should be terminated, because it is not invoked to shield the conduct that the plaintiff challenges. ${ }^{79}$ Second, the court noted that the major prior cases outside of Delaware that had upheld a decision not to sue had involved third-party litigation or had otherwise been cases in which no evidence existed to overcome or suspend the normal presumption in favor of the directors. ${ }^{80}$

Finally, and perhaps most importantly, the Delaware court traced the historical evolution of the derivative suit, emphasizing its dual nature as both an individual suit against the corporation to compel a suit and a suit by the corporation against the alleged wrongdoer. This distinction was critical to the court, because in its view, the first suit's individual character precluded the existence of any substantive standing requirement: "It is this dual nature of the derivative suit which denies the corporation the right to compel the dismissal of a properly brought stockholder's derivative action, because the stockholder asserts in the suit not only a right belonging to the corporation but also a right individual to himself." " obligation to show that the board's decision was unsound.

Unlike the first two arguments in Maldonado II, which are highly cogent, the argument that the derivative suit belongs to the individual as well as to the corporation seems opaque and overbroad. Although the derivative action does indeed consist of two actions, they are not parallel and coextensive, but rather vertically integrated: the individual action is analogous to a writ of mandamus against a public body to perform an official duty-namely, bringing suit to redress a breach of fiduciary duty. If the derivative action were truly "individual" in character, then logic would equally require that it be immune from all the other procedural barriers surrounding the derivative action and indeed that a successful plaintiff bear his own legal expenses rather than look to the corporation for an award. In principle, the benefits and the burdens of the action are difficult to separate. Undoubtedly, the Delaware court did not intend to write so broadly, but this "individual action" rationale does not seem easily contained.

78. Id. at 1256 .

79. Id. at 1257 .

80. Id. at $1258-60$.

81. Id. at 1262. The court relied heavily on Sohland v. Baker, 15 Del. Ch. 431,141 A. 277 (Del. 1927). One commentator has observed that the case is "pivotal" to the vice chancellor's reasoning, but that it is misplaced authority because the directors who rejected the suit in that case were not disinterested. Hinsey, Maldonado (N.Y.) v. Maldonado (DE): Which Prevails?, Legal Times (Wash.), Aug. 4, 1980, at 18, col. 1. However, the court did not cite Sohland as authority for its view of the business judgment rule, and thus it does not seem pivotal to its reasoning. Moreover, the fact that the board was interested in its decision not to sue should not logically affect the court's analysis of the basic nature of the derivative action (i.e., whether it was in part an "individual action"). 
Thus, Maldonado II seems correctly decided, but at least partially for the wrong reasons. In this light, the facts of the case may deserve greater attention than its formal reasoning. Above all, Maldonado involves self-dealing, rather than simply a violation of the duty of due care. This distinguishes it from the great majority of recent cases, which involved illegal payments, and in which courts were asked to enforce the duty of due care against directors who in most instances had not been personally involved in the illegal transactions. ${ }^{82}$ In all likelihood, courts are reluctant to impose draconian penalties in an area characterized by evolving moral standards; in addition, they may suspect (but not wish to state) that the illegality caused no net loss to the corporation since the illegal payments may have secured profitable contracts in excess of the penalties imposed. In this context, the court has strong incentives to accept the decision not to sue and thus to avoid a thicket of problematic issues.

In those cases that do not fit this pattern, the recent judicial response has been far less consistent or predictable. The Maldonado cases, Galef $v$. Alexander ${ }^{83}$ and Lewis $v$. Anderson ${ }^{84}$ all involved the propriety of stock options, and in particular the substitution of newer, more favorable options for existing ones. In Galef and Maldonado II, the courts did not accept the business judgment rejection. ${ }^{85}$ In Lewis and Maldonado I, where the defense was accepted, the courts may have seen the issue as only one of executive compensation, which they may have considered either too mundane or too unmanageable for close judicial attention. For example, in Lewis v. Anderson, Walt Disney Productions granted new stock options through the "stock option committee" of its board, but then obtained shareholder ratification, which plaintiffs asserted violated the federal securities laws. ${ }^{86}$ Absent authority in the board to terminate, this action would probably still have been dismissed on the grounds that the stock options fell within the ordinary "business judgment" discretion of the board.

At the other extreme, two recent cases suggest that when a major selfdealing transaction attempts to transform the basic structure of the corporation, courts will be reluctant to allow directors to terminate derivative suits challenging the transaction. In Swenson v. Thibaut, ${ }^{87}$ the North Carolina Court of Appeals rejected a decision not to sue in a case involving significant transactions between a parent and its partially owned subsidiary. The court assumed that a standing requirement existed, ${ }^{88}$ but found the "disinterested" directors to lack

82. See cases cited in note 57 supra.

83. 615 F.2d 51 (2d Cir. 1980).

84. 615 F.2d 778 (9th Cir. 1979), cert. denied, 101 S. Ct. 206 (1980).

85. In Genzer v. Cunningham, 498 F. Supp. 682 (E.D. Mich. 1980), the court suggested that the lime between Maldonado II and cases accepting business judgment decisions may depend on the presence or absence of "personal gain by the direetors." Id. at 688. Such an analysis is consistent with our own.

86. Lewis v. Anderson, 615 F.2d at 780.

87. 39 N.C. App. 77, 250 S.E.2d 279 (1978).

88. Id. at 105.06, 250 S.E.2d at 297. 
the requisite independence. However, other facts suggest that the court had ample reason to be suspicious of the defendants. ${ }^{89}$

More recently, in Clark v. Lomas \& Nettleton Financial Corp.,$^{90}$ the Fifth Circuit permitted a derivative action to continue, where subsequent to the filing of the action the board entered into a settlement with the defendants, who included the two controlling shareholders of the corporation. The critical fact in Clark appears to have been that each director who voted to approve the settlement had been nominated and elected by the votes of the two principal corporate defendants. ${ }^{91}$ Yet such a test is potentially broader than it first appears, for frequently directors are understood to be the nominees of a particular shareholder. Thus, although both Clark and Swenson might be viewed simply as decisions that the board was not "disinterested," they are probably better read as showing a judicial unwillingness, at least in cases involving significant self-dealing by controlling shareholders, to deny the plaintiff his day in court based only on the board's perception of the corporate self-interest.

To summarize, the "clear trend in corporate law" seen by the Ninth Circuit in Lewis $v$. Anderson ${ }^{92}$ may be more illusory than real. At present, there are multiple trends. At least one court has accepted Maldonado II as a correct statement of Delaware law, ${ }^{93}$ and a thoughtful opinion by Judge Merhige has declared it also to represent the law of Virginia." Another approach, taken by a Texas court, is to delay acceptance of a board's decision not to sue until at least a preliminary review of the merits has been undertaken by the court.95 Conversely, one recent federal court opinion has raised the troubling theme that unless state law recognizes the board's power to terminate derivative litigation, a disincentive will arise for businesses to incorporate in that jurisdiction..$^{96}$ Once raised, this argument may well lead to the "race to the bottom," which Professor Cary has suggested undermines state efforts at reforming corporation laws, ${ }^{97}$ and the "clear trend" discerned in Lewis may be that dictated by Gresham's Law.

89. The subject corporation, an insurance company, had been placed in "involuntary rehabilitation," and the state Commissioner of Insurance had determined that the continuation of "present management would be hazardous to the shareholders and policyholders of the company." Id. at $84-85,250$ S.E. $2 \mathrm{~d}$ at 285.

90. 625 F.2d 49 (5th Cir. 1980).

91. Id. at 52.

92. 615 F.2d 778, 783 (9th Cir. 1979), cert. denied, 101 S. Ct. 206 (1980). See text accompanying note 46 , supra.

93. Maher v. Zapata Corp., 490 F. Supp. 348 (S.D. Tex. 1980).

94. Abella v. Umiversal Leaf Tobacco Co., 495 F. Supp. 713 (E.D. Va. 1980).

95. Sonics Int'1, Inc. v. Dorchester Enterprises, Inc., 593 S.W.2d 390 (Tex. Civ. App. 1980).

96. See Genzer v. Cunningham, 498 F. Supp. 682, 688 (E.D. Mich. 1980) (noting that Michigan in framing its law wished to be competitive with New York, which in Auerbach v. Bennett, 47 N.Y.2d 619, 393 N.E.2d 994, 419 N.Y.S.2d 920 (1979), recognized the defense). Ironically, this leads to the result that those jurisdictions that have longed to "out-Delaware" Delaware may nowafter Maldonado II and Auerbach-seek to "out-New York" New York.

97. See generally, Cary, Federalism and Corporate Law: Reflections Upon Delaware, 83 Yale L.J. 663 (1974)., There has been a lengthy debate over this thesis, and it is beyond the scope of this Article. 


\section{B. The Scope of Judicial Review}

Prior to Burks, several cases had indicated that a court need not accept a "grossly unsound" business judgment.98 After Burks, it is clear that a court must review the decision at least to the extent that a federal policy might be implicated. But where federal policy is not implicated, some decisions have now held that substantive judicial review is at an end, the only reviewable issues being the good faith and independence of the directors making the decision. The strongest statement to this effect is that of the New York Court of Appeals in Auerbach $v$. Bennett. ${ }^{99}$ Auerbach involved the familiar pattern of foreign bribes and kickbacks, paid in this instance by General Telephone \& Electronics Corporation to foreign governmental customers. The decision not to sue was reached by a committee of three directors who had joined the board after the transactions in question. The trial court granted defendant's motion for summary judgment, based on this decision. ${ }^{100}$ The Appellate Division reversed, holding simply that summary judgment would require a fuller statement of the factors relied upon by the committee and the relative weight accorded them. Specifically, it asked the board to develop "the reasons for the payments, the advantages or disadvantages accruing to the corporation by reason of the transactions, the extent of the participation or profit by the respondent directors and the loss, if any, of public confidence in the corporation which might be incurred." ${ }_{101}$ Reversing the Appellate Division, the New York Court of Appeals stated that such information was unnecessary because substantive judicial review of a board's decision was unavailable. ${ }^{102}$ Then, in a broad conclusory statement, it justified this rule: "To permit judicial probing of such issues would be to emasculate the business judgment doctrine as applied to the actions and determinations of the special litigation committee. 1ts substantive evaluation of the problems posed and its judgment in their resolution are beyond our reach." ${ }^{103}$

To date, no recent decision has squarely taken issue with Auerbach's reasoning. Indeed, Judge Weinfeld in Maldonado I clearly indicated that even a meritorious action might be dismissed..$^{\text {tos }}$ The logic of Auerbach's iron rule will be scrutinized later, ${ }^{105}$ but here a conflict in the case law is apparent: Swenson, Clark, and Maldonado II have each rejected board decisions at least in part because the court found them unpersuasive.

\section{The Procedural Issues}

A two-pronged consensus has developed concerning the procedural requirements a decision to terminate must meet if a court is to accept it. First, the

98. See, e.g., Gall v. Exxon Corp., 418 F. Supp. 508, 516 (S.D.N.Y. 1976).

99. 47 N.Y.2d 619, 393 N.E.2d 994, 419 N.Y.S.2d 920 (1979).

100. See Auerbach v. Bennett, 64 A.D.2d 98, 103, 408 N.Y.S.2d 83, 85 (1978).

101. Id. at 107,408 N.Y.S.2d at $87-88$.

102. Auerbach v. Bennett, 47 N.Y.2d at 633,393 N.E.2d at 1002,419 N.Y.S.2d at 928.

103. Id. at 634,393 N.E. $2 d$ at 1002,419 N.Y.S.2d at 928.

104. Maldonado v. Flynn, 485 F. Supp. at 285.

105. See notes $128-30$ and accompanying text infra. 
decision not to sue can be made only by an independent, disinterested body. Second, the procedures employed by the board and the impartiality shown by those conducting the inquiry will be the best evidence of their good faith. ${ }^{106}$ Thus, where a de facto decision to resist the suit appeared to have been made by the board before the special litigation committee reported its findings, the decision not to sue was rejected. ${ }^{107}$ Some evidence that an independent judgment was in fact exercised by those delegated the responsibility must affirmatively appear in the record. ${ }^{103}$

Substantial doubt, however, exists that a board can reach a decision not to sue where all of its directors have been made defendants. In Galef $v$. Alexander, ${ }^{109}$ such a decision was rejected at least in part on this ground. But this approach creates a paradox. Plaintiffs could seemingly evade the defense simply by naming every director as a defendant and alleging that even if the director was not directly involved in the transaction, he was negligent in failing to detect the alleged fraud. Clearly, this would create a strong incentive for manufactured pleadings. Yet the issue is not new. Courts have divided for over a decade on the analogous question of whether demand will be excused when the plaintiff makes similar charges against the board or a majority thereof. ${ }^{110}$ Cynical as such

106. Auerbach expressly recognizes that courts may and should review "the methodologies and procedures" employed by the board in their "investigation of facts and the determination of legal liability." Auerbach v. Bennett, 47 N.Y.2d 619, 634, 393 N.E.2d 994, 1002, 419 N.Y.S.2d 920, 929 (1979). The guidelines in this area are well discussed in Dent, supra note 13, at 128-29.

107. Swenson v. Thibaut, 39 N.C. App. 77, 250 S.E.2d 279, appeal denied, 296 N.C. 740 , 254 S.E.2d 181 (1979). One day before appointing an advisory "litigation evaluation committee" (composed of disinterested directors but lacking any real power) the full board, of which defendants constituted a majority, had already moved to disqualify plaintiff's counsel, thus indicating their hostility toward the litigation. Cf. Nussbacher v. Continental Ill. Nat'l Bank \& Trust Co., 518 F.2d 873 (7th Cir. 1975) (where, pursuant to notification of plaintiff's intent to bring suit, a majority of the board rejected the suit on behalf of the corporation, there was no need for plaintiff to make a formal demand under Fed. R. Civ. P. 23.1), cert. denied, 424 U.S. 928 (1976).

108. See Casey v. Woodruff, 49 N.Y.S.2d 625, 642-47 (Sup. Ct. 1944). The directors of the Erie Railroad Company decided to refinance the company through a bond issue, but did not resort to competitive bidding for the bonds. The court found that because four members of the board had tested the bond market to determine a fair price, and because they could articulate why they had limited themselves to one investment banker, their decision was a proper exereise of business judgment (although not necessarily the best decision).

109. 615 F.2d 51 (2d Cir. 1980).

110. Compare Barr v. Wackman, 36 N.Y.2d 371, 329 N.E.2d 180, 368 N.Y.S.2d 497 (1975) (plaintiff's allegations of breach of fiduciary duty on the part of the "unaffiliated" majority of the board in participating in and approving acts of bias and self-dealing by "affiliated" minority directors held sufficient to withstand motion to dismiss for failure to make a demand), with In re Kauffman Mut. Fund Actions, 479 F.2d 257 (1st Cir.) (plaintiff's allegations of domination and control by "affiliated" directors did not satisfy the requirement of "particularity" in rule requiring that a complaint allege with particularity the reasons for not making demand; defendant's motion to dismiss granted), cert. denied, 414 U.S. 857 (1973). See also Nussbacher v. Continental Ill. Nat'l Bank \& Trust Co., 518 F.2d 873 (7th Cir. 1975) (dismissal of the suit held inappropriate because evidence was sufficient to show that the majority of the board was inflexible in its position that the corporation would take no action against the derivative suit defendant), cert. denied, 424 U.S. 928 (1976); Jannes v. Microwave Communications, Inc., 57 F.R.D. 18 (N.D. Ill. 1972) (excusing demand where the complaint had alleged alternative theories of wrongdoing on the part of all directors). 
a ploy by plaintiffs may seem, defendants have found a correspondingly clever tactic to counter it: the challenged board simply appoints new members and delegates the decision to them. ${ }^{111}$ Both Maldonado I ${ }^{112}$ and Lewis $v$. Anderson ${ }^{113}$ rejected the argument that such newly installed directors were not "independent" because they owed their position to the defendants. On the other hand, both Swenson and Clark rejected board decisions where the directors involved had been nominated and elected by the principal defendants. ${ }^{14}$ Obviously, there is a tension between Maldonado I's acceptance of this tactic and these decisions' rejection of it. Particularly in this area, a common law approach scems both inherently inadequate and inferior to a "brigbt-line" legislative standard, which would prevent insiders from maintaining a "tame" special litigation committee.

\section{From Precedent to Policy: The IMPACt of a Standing ReQuirement}

Can a substantive standing requirement be reconciled with the concept of corporate accountability? In the wake of Burks, this is the critical policy issue. That Burks, Auerbach, and other recent cases may represent a departure from the prior case law, as we have argued, is not in itself significant unless the consequences of this change are destructive to the goal of accountability. Undoubtedly, this danger is real; but Maldonado II, in its total rejection of the directors' authority to terminate a derivative suit, represents an unnecessarily extreme answer.

To understand what limitations on Burks are desirable, it is necessary to survey the policy interests it affects. Our discussion of these interests is organized around three general issues: (I) the relationship of the standing requirement to the business judgment rule; (2) the effect of a standing requirement on existing state law doctrines concerning the regulation of corporate affairs; and (3) the possible federal policies that might be "frustrated" by such a defense.

\section{A. The Business Judgment Rule and the Decision Not to Sue: Contextual Differences}

The power to decide not to sue has been characterized as simply an extension of the business judgment rule; in this light, the power not to sue is but the correlative of the unchallenged power to sue. ${ }^{115}$ This characterization, however,

111. Maldonado v. Flynn, 485 F. Supp. at $277-78$; Swenson v. Thibaut, $39 \cdot$ N.C. App. at 105-07, 250 S.E.2d at 297-98; Brody v. Chemical Bank, 517 F.2d 932, 933-34 (2d Cir. 1975) (per curiam) (affirming dismissal of amended complaint for failure to allege demand on new board mem* bers rather than on directors im office wheu suit was commenced).

112. Maldonado v. Flynn, 485 F. Supp. at 283-84.

113. 615 F.2d 778, 782-83 (9th Cir. 1979), cert. denied, 101 S. Ct. 206 (1980). The dubiousness of the independence of directors under these circumstances is thoughtfully expressed by Professor Dent. See Dent, supra note 13, at 111-17.

114. Swenson v. Thibaut, 39 N.C. App. at 106-08, 250 S.E.2d at 297-98; Clark v. Lomas \& Nettleton Financial Corp., 625 F.2d 49, 52-53 (5th Cir. 1980).

115. See United Copper Sec. Co. v. Amalgamated Copper Co., 244 U.S. 261, 263-64 (1917) ("Whether or not a corporation shall seek to enforce in the courts a cause of action for damages is, 
misapprehends the business judgment rule, seeing it as an across-the-board protection rather than as the highly contextual and policy-oriented doctrine that it is. ${ }^{116}$ The decision not to sue typically occurs in a very different context from that of the normal business judgment. Four distinctions stand out, and each makes the case for judicial deference to board decisions not to sue far less persuasive than in the context of the ordinary business decisions.

First, normal business judgments are often made under time pressure and uncertainty, which preclude studied reflection or textbook-style decisionmaking. Time is money, and excessive prudence can be more a vice than a virtue. The business judgment rule properly recognizes and tolerates these factors, in order to encourage entrepreneurial risktaking. In contrast, a decision to terminate litigation generally permits greater time for investigation; uncertainty is less a factor because the facts now exist in history rather than lying unknowably in the future.

Second, in its normal operation, the business judgment rule insulates corporate officials from liability for decisions made in the exercise of business judgment. ${ }^{117}$ In this sense, the substantive decision is immunized from judicial review in order to protect the decisionmaker. But directors who decide to terminate a derivative action need no such blanket of immunity, because they face little

like other business questions, ordinarily a matter of internal management and is left to the discretion of the directors . . . "); Auerbach v. Bennett, 47 N.Y.2d 619, 393 N.E.2d 994, 419 N.Y.S.2d 920 (1979) (decision not to sue is a "second tier" business decision). Even decisions that have rejected the board's attempt to terminate a derivative action have recognized a close linkage between the decision not to sue and the business judgment rule. See Galef v. Alexander, 615 F.2d 51,57 n.13 (2d Cir. 1980). Nonetheless, this Article submits that the policy interests underlying judicial deference to ordinary (or "first tier") business decisions are significantly different from, and stronger than, those associated with the decision to terminate a derivative action. To date only the Delaware court in Maldonado II has focused on these differences. Maldonado v. Flynn, 413 A.2d 1251, 1257-62 (Del. Ch. 1980), rev'd and remanded sub nom. Zapata Corp. v. Maldonado, No. 113, 1980 (Del. May 13, 1981).

One commentator, while disagreeing with the Delaware court in Maldonado II, would uphold the board's action as a proper function of the business judgment doctrine, rather than the business judgment rule. Hinsey, supra note 81 . The difference between the two concepts is that while the rule only protects first-tier decisionmaking from liability, the doctrine supports the power of an independent board to govern the corporation - presumably free from judicial or, for that matter, shareholder interference.

We cannot fully accept this distinction. While we do not advocate close judicial scrutiny of board decisions generally, and in fact propose only an intermediate standard of judicial review, see proposed $\S 49(f)$ in Appendix infra, we believe that the corollary of the board's power to govern the corporation is its duty to do so. This duty requires some mechanism for its enforcement, which in theory the derivative suit has traditionally afforded.

116. See Manne, Our Two Corporation Systems: Law and Economics, 53 Va. L. Rev. 259, 270-72 (1967), discussing the development and function of the business judgment rule. Manne suggests that the rule effectively precludes the courts from any consideration of an "honest if inept" business decision, while providing liability for the actions of dishonest, disloyal, or grossly negligent directors. Professor Manne believes that the rule is principally grounded on the desirability of preventing courts from exercising regulatory control over corporate managers.

117. Traditionally, the business judgment rule only protects corporate officials who have exercised due care and acted upon a reasonable basis in good faith. See Arsht, The Business Judgment Rule Revisited, 8 Hofstra L. Rev. 93, 134 (1980) (arguing that plaintiff may hold liable a corporate official who "did not exercise the care an ordinarily prudent person in a like position would use under similar circumstances," notwithstanding the business judgment rule). See also Casey v. Woodruff, 49 N.Y.S.2d 625, 642-43 (Sup. Ct. 1944) (similar formulation under New York law). 
risk of liability. ${ }^{118}$ By definition, they are not defendants in the action they seek to terminate, and their decision to terminate, even if erroneous, would be protected by the ordinary operation of the business judgment rule insofar as their own liability is concerned. Indeed, when a court rejects a board's decision to terminate an action, it simply restores the lawsuit, and little damage to the corporation can arise in the brief interval. Because this type of decision is revocable without adverse effect to the corporation, it does not (unlike an imprudent investment decision) afford an occasion for liability. ${ }^{119}$ Uniquely, then, the decision not to sue presents a context in which the issue of a decision's wisdom can be severed from the distinct issue of the need to protect directors from an excessive exposure to personal liability. The social policies that underlie the business judgment rule (e.g., the need to encourage entrepreneurship and socially desirable risktaking) are not here implicated, because personal liability of the directors does not follow in the wake of a reversal of their decision. Perceptively, Maldonado II so recognized. ${ }^{20}$

Third, although most business decisions are not amenable to judicial review, ${ }^{121}$ the decision to terminate a derivative action inherently involves the creation of a reviewable record. ${ }^{122}$ It is a retrospective decision, rather than a predictive one, and the court is therefore better able to sift and balance the same evidence as was presented the board. ${ }^{123}$ Those talents that a court is generally

118. There seems little doubt that if a plaintiff sought to hold directors liable for losses resulting from a decision on their part to seek dismissal of a derivative action, the directors could raise the defense of the business judgment rule. Maldonado II so recognizes in distinguishing the issue of the liability of the directors from that of the reviewability of the decision:

While the business judgment rule may protect the Committee of Independent Directors of

Zapata from personal liability if they have made a good faith decision that this suit is not in

the best interests of Zapata, and should be dismissed, an analysis of the character of a

derivative suit shows that the business judgment rule is irrelevant to the question of whether

the Committee has the authority to compel the dismissal of this suit.

Maldonado v. Flynn, 413 A.2d at 1257.

119. In some rare instances, damage to the corporation might occur if the directors delayed the suit sufficiently to frustrate a recovery (e.g., the defendant becomes insolvent or flees the jurisdiction). Even in these instances, however, a good faith judgment by the board will be protected by the normal business judgment rule, unless patently unreasonable.

120. Maldonado II charaeterizes the business judgment rule first "as a defensive rule" and then as "a shield with which direetors may oppose stockholders' attacks on the deeisions made by them." Maldonado v. Flynn, 413 A.2d at 1256, 1257. This sword-shield distinction makes particular sense in the case of judicial review of a board's decision not to sue: judicial reversal of such a decision should not make the directors who are responsible for it liable, but correspondingly, as the exposure to liability is reduced, so is a major reason for judicial deference.

121. See Manne, supra note 116 , at 270-72.

122. While it may be insignficant in other business decisions, a reviewable record is an inherent part of the decision not to sue. Auerbach $v$. Bennett expressly recognized that judical review was appropriate "[a]s to the methodologies and procedures" used by the board. 47 N.Y.2d 619, 634, 393 N.E.2d 994, 1002, 419 N.Y.S.2d 920, 929 (1979). Thus, to protect its decision, the board must demonstrate a careful review of the relevant evidence. But, as Auerbach further states, courts are "better qualified" than corporate directors to perform such a review, id., and thus again the usual rules for judieial deference are less applicable.

123. In other areas of the law, courts have recognized that retrospective decisions are more amenable to judicial review than forward-looking decisions. Essentially, the Supreme Court made this distinction in Greenholtz v. Inmates of the Neb. Penal \& Correctional Complex, 442 U.S. 1 (1979), in holding that the parole decision (which in the Court's view was a prediction about future 
thought to lack-business intuition, a feel for the marketplace, and the ability to trade off risk against return-are not here called for to the same degree. Indeed, to the extent that the determination hinges on an appraisal of the merits of the litigation, the court's perspective and expertise are superior to the board's.

Finally, there is the problem of structural bias in board determinations. Others have collected the empirical evidence that board members are still typically selected and regularly dismissed by the company's senior management. ${ }^{124}$ At first glance, this vulnerability of board members might seem to apply equally to all board decisions, and therefore not distinguish the special case of a decision not to sue. But shades of difference exist, and this process of director selection and socialization, which incumbent management dominates, may cause even the outside director to perceive his role, once litigation is commenced, as that of a buffer by which to shelter and protect management from hostile and litigious stockholders. In particular, a derivative action evokes a response of group loyalty, ${ }^{125}$ so that even a "maverick" director may feel compelled to close ranks and protect his fellows from the attack of the "strike suiter." ${ }^{26}$ As a result, an outside director independent enough to oppose the chief executive officer with respect to a proposed transaction that he thinks is unfair or unwise may still be unable to tell the same officer that he thinks a suit against him has sufficient merit to proceed. ${ }^{127}$ The latter vote would be a far more personal and stigmatizing form of opposition. In short, prospective rejections can be diplomatic and couched in terms of the appearances of impropriety, but a refusal to protect one's peers once events have transpired is seen as disloyal treachery.

behavior by the inmate) could not be subjected to the requirements of due process, even though the parole revocation decision (which focuses on prior conduct) is so constrained. Id. at 12-13. Correspondingly, the typical investment or business-planning decision is more prospective in orientation than is the decision not to sue (which by definition focuses on prior conduct), and so merits greater judicial deference.

124. For a variety of reasons, most studies find the outside director still "economically or psychologically dependent upon or tied to the corporation's executives, particularly its chief executive." M. Eisenberg, The Structure of the Corporation 145 (1976); Solomon, Restructuring the Corporate Board of Directors: Fond Hope-Faint Promise?, 76 Mich. L. Rev. 581, 584-86 (1978). See generally Mace, Directors: Myth and Reality-Ten Years Later, 32 Rutgers L. Rev. 293, 307 (1979). Beyond the obvious reasons for such domination-e.g., economic inducements, family ties, or personal selection of the outside director by the chief executive-a more fundamental problem may be the "structural bias" that grows out of a business ethic under which directors are expected to "protect" management from attacks by outsiders. See Note, supra note 13, at 619-22 (surveying recent findings that directors are recruited, nominated, and removed by the chief executive officer).

125. An experienced attorney who has counselled outside directors in the context of a special committee's review of a shareholder's action explains the intensity of this group loyalty in the following terms: "[W]e are dealing with a situation in which the President of the company, the man or men who helped build it, and who the directors view as an irreplaceable asset, has his honor and future under attack. Such men look to 'their' board of directors to support them." Klein, Conduct of Directors When Litigation is Commenced Against Management, 31 Bus. Law. 1355, 1359 (1976). Of course, the fact that the chief executive officer may be able to remove a "disloyal" director through his control of the corporation's proxy machinery may serve to reinforce this sense. A 1971 study found that $37 \%$ of chief executive officers surveyed had removed directors for various reasons. See Heidrick \& Struggles, Inc., Profile of the Board of Directors 11 (1971).

126. Professor Buxbaum has also detailed this argument, and we concur with his analysis. See Buxbaum, supra note 13 .

127. Our premise that outside directors find some decisions easier than others cannot easily be empirically proved. But anecdotal evidence suggests that even "maverick" directors accept the prin- 
Even if the decision not to sue is treated as simply an aspect of the business judgment rule, ${ }^{128}$ it does not follow that the substance of the decision should be beyond judical review. Although Auerbach apparently permits review only of the process and procedures leading up to the decision, this result conflicts with the traditional understanding of the business judgment rule as permitting a limited degree of judicial review. In a recent Article, two leading members of the corporate bar (neither of them known for excessive sympathy to plaintiff causes) argue persuasively that a reasonableness test has always lurked "as a hidden reef in the business judgment rule safe harbor," and that such a requirement is desirable. ${ }^{129}$ If so, it must lurk as well in the business judgment not to sue. The Third Circuit appears to have recognized this in Cramer $v$. General Telephone \& Electronics Corp.:

[W]e do not think that the business judgment of the directors should be totally insulated from judicial review. . . . [W] [Were the shareholder contends that the directors' judgment is so unwise or unreasonable as to fall outside the permissible bounds of the directors' sound discretion, a court should, we think, be able to conduct its own analysis of the reasonableness of that business judgment. ${ }^{130}$

In terms of the policies underlying judicial deference to directorial discretion, then, the decision not to sue is a less favored decision, which merits closer judicial scrutiny. But Auerbach, paradoxically, has made it a more favored decision, which, if the New York Court of Appeals means what it has said, carries greater immunity than the "true" prospective business judgment made under conditions of uncertainty. This result, we suggest, invites legislative reexamination.

\section{B. The Frustration of State Policy}

Burks dealt only with the issue of when a business judgment not to sue is inconsistent with a federal policy; it did not, understandably, face the analogous issue of whether such a decision can conflict with a state policy as well. Because

ciple that "when the chips are down," an outside director must either support his chief executive or resign form the board. See J. Bacon \& J. Brown, The Board of Directors: New Challenges, New Directions 30 (1972). See also E. McSweeney, Managing the Managers 106 (1978). See also Lasker v. Burks, 567 F.2d 1208, 1212 (2d Cir. 1978) ("It is asking too much of human nature to expect that the disinterested directors will view with the necessary objectivity the actions of their colleagues in a situation where an adverse decision would be likely to result in considerable expense and liability for the individuals concemed."), rev'd on other grounds, 441 U.S. 471 (1979). While the Second Cireuit was here addressing the special context of investment companies, the critical fact cited was that a majority of the board was constituted by "inside" directors. Accordingly, our proposed statute limits the defense to corporations having a majority of independent directors. See proposed $\$ 49(f)$ in Appendix infra.

128. See Hinsey, supra note 81 .

129. Arsht \& Hinsey, Codified Standard-Safe Harbor But Charted Channel: A Response, 35 Bus. Law. 947, 962 (1980).

130. 582 F.2d 259, 275 (3d Cir. 1978). 
the corporation is a "creature of state law" and hence primarily subject to state policies, this may ultimately prove a more important boundary on the decision than the federal limit announced in Burks. This Article discusses three state policies that may conflict with the decision not to sue (though undoubtedly other examples could be used): the rule of Remillard Brick ${ }^{131}$ that self-dealing transactions are not made immune from plaintiff attack by board ratification; the corporate opportunity doctrine, which in some formulations requires prospective disclosure and ratification; ${ }^{132}$ and the deterrent theory of the derivative suit set forth in Diamond v. Oreamuno. ${ }^{133}$

By statute in most jurisdictions a transaction between a director and his corporation is no longer void, or even voidable at the election of the corporation, if the transaction was approved by the vote of a disinterested board after full disclosure. ${ }^{134}$ Despite the seemingly dispositive effect these statutes give to board approval, courts have construed them more narrowly, setting aside the transaction if the plaintiff can prove unfairness to the corporation. ${ }^{135}$ Professor Henn has summarized these cases as reading the statute so as to "neutralize the adverse inferences which would otherwise arise, thus subjecting those seeking to set aside the transaction or to surcharge the fiduciaries to the burden of showing the required fraud or unfairness." 136 Thus, the effect of these statutes, so construed, is to shift the burden of proof: in their absence, defendant must show the transaction to be fair; in their presence, plaintiff must prove fraud or unfairness. ${ }^{37}$

In effect, the majority rule preserves the plaintiff's right to challenge a self-dealing transaction, notwithstanding board ratification. But this right will be lost if instead of ratifying the board can make a business judgment to foreclose suit. ${ }^{138}$ An inconsistency seems apparent here: in the face of legislative approval of board ratification, courts still retained an opportunity for judicial review of the fairness of a self-dealing transaction, notwithstanding the argument that the board knew best; but this opportunity is lost if the board can now style its approval differently.

A second example of an established state rule that seems to dissolve in the universal solvent of the business judgment defense is one version of the corpo-

131. Remillard Brick Co. v. Remillard-Dandini Co., 109 Cal. App. 2d 405, 418-20, 241 P.2d 66, 73-75 (1952).

132. See, e.g., Moses v. Burgin, 445 F.2d 369 (1st Cir. 1971).

133. 24 N.Y.2d 494, 248 N.E.2d 910, 301 N.Y.S.2d 78 (1969).

134. See, e.g., Model Business Corporation Act Annot. § 41; Marsh, Are Directors Trustees? Conflict of Interest and Corporate Morality, 22 Bus. Law. 35, 44-48 (1966) (discussing the evolution of the "faimess doctrine," citing case law in inore than twenty states that follow the doctrine and statutes similar to $\S 41$ that have been enacted in many states).

135. Id. at 46-48; see also Remillard Brick Co. v. Remillard-Dandini Co., 109 Cal. App. 2d 405, 241 P.2d 66 (1952); Scott v. Multi-Amp Corp., 386 F. Supp. 44, 67-68 (D.N.J. 1974) (burden still on directors, but with less stringent standard).

136. H. Henn, Corporations $\S 238$, at 469 (2d ed. 1970) (footnotes omitted).

137. In soine circumstances, the burden does not shift to the plaintiff and the defendant remains subject to the burden of proving the faimess of the transaction. See Fliegler v. Lawrence, 361 A.2d 218 (Del. 1976).

138. For a more detailed analysis of this area and the relevant policy implications, see Buxbaum, supra note 13 , at $1124-27$. 
rate opportunity doctrine. In some jurisdictions, an arguable corporate opportunity must be disclosed to the board and rejected before a person having a fiduciary relation to the corporation may accept it. Thus, in Kerrigan $v$. Unity Savings $A s s^{\prime} n,^{139}$ the failure to make prior disclosure resulted in the court's refusal to accept both the argument that the opportunity would have been illegal for the corporation to accept and the claim that the opportunity would have been declined if presented to the corporation. Instead, the Illinois Supreme Court held that the "prophylactic purpose of the rule" required it to presume that the opportunity would have been accepted had the corporation been given the "opportunity to decide." ${ }^{140}$ If the policy of this case and others like it ${ }^{141}$ is to enforce prior disclosure, such a policy is vitiated by an unreviewable decision not to sue. ${ }^{142}$ Cases such as Kerrigan seem to rest on an implicit judicial view that directorial action taken before the event is more likely to be fair, reliable, and independent than a ratification decision made after the litigation is commenced. If so, it would again elevate form over substance to accept simply a different means of post-hoc approval by the board of a self-dealing transaction.

A third example involves the issue of whether there must be a "net loss" to the corporation to support a derivative action. In Diamond $v$. Oreamuno, ${ }^{143}$ the New York Court of Appeals held two executives liable to their corporation for insider trading. In its opinion, the court stated that it is not always necessary for a derivative suit to contain an allegation of damage to the corporation, ${ }^{144}$ and that the purpose of the derivative suit "is not merely to compensate the plaintiff," but to deter. ${ }^{145}$ After Auerbach, however, the same suit could apparently be dismissed if the board declined to sue, giving as its reason that the corporation had suffered no loss. Even if less troublesome reasons are given, the deterrent function of the derivative suit is substantially sacrificed.

Another New York case suggests that the conflict here is even broader. In Abrams $v$. Allen ${ }^{146}$ the New York Court of Appeals appeared to announce a "public policy" doctrine: actions taken in violation of public policy can be challenged by a derivative action. ${ }^{147}$ Yet in Auerbach, the court read the business judgment doctrine to give the board exclusive jurisdiction over the "weighing and balancing of legal, ethical, commercial, promotional, public relations, fiscal and other factors." 148 Although the court elsewhere acknowledged that the

139. 58 Ill. $2 d 20,317$ N.E.2d 39 (1974).

140. Id. at $28-29,317$ N.E.2d at $43-44$.

141. E.g., Moses v. Burgin, 445 F.2d 369 (1st Cir., 1971). The court in Moses v. Burgin announced that it would presume that an opportunity not presented to the corporation would have been accepted by it.

142. See id. at 376-79. The First Circuit reviewed management's duty to disclose its conflicts of interest to the disinterested directors, and ramifications of its failure to do so. The court imposed damages on the directors who failed to disclose, to the extent of the opportunity that was lost. The Second Cireuit reaehed a similar result in Fogel v. Chestnutt, 533 F.2d 731 (2d Cir. 1975).

143. 24 N.Y.2d 494, 248 N.E.2d 910, 301 N.Y.S.2d 78 (1969).

144. Id. at 498,248 N.E. $2 d$ at 912,301 N.Y.S.2d at 81.

145. Id. (emphasis omitted).

146. 297 N.Y. 52,74 N.E.2d 305 (1947).

147. Id. at 56,74 N.E.2d at 307.

148. Auerbach v. Bennett, 47 N.Y.2d at 633,393 N.E.2d at 1002,419 N.Y.S.2d at 928 (1979) (emphasis added). 
board's discretion was limited to decisions made "in the lawful and legitimate furtherance of corporate purposes," ${ }^{149}$ the first phrasing, which assigns no priority to ethical considerations, appears to cancel out the suggestion of Abrams that actions not specifically illegal could still be challenged by a derivative suit.

We do not here contend that Abrams was right and Auerbach wrong, or that the deterrent objectives of Diamond can be fully realized. Our point is more modest: the cases must be read together. Otherwise, absurdities result. In this light, Auerbach is overwritten; some measure of substantive review must be retained by a court considering a board's decision not to sue. Our position is not that the policies we describe compel the court to insist that a derivative suit proceed, but only that the court must have a measure of discretion if the deterrent role of the derivative action is to survive.

On the other hand, this position does not compel acceptance of Maldonado II's apparent total rejection of the substantive standing requirement. If the frustration of state policies is to be our touchstone, a strong state policy must still be recognized in encouraging independent and energetic boards of directors. Little will more discourage their development than the result of Maldonado II, which effectively denies them any decisionmaking role in derivative litigation. Conversely, the knowledge that an independent board has the power to terminate derivative litigation encourages corporate insiders to protect themselves by establishing an independent director representation on their board. Of course, the insider's real incentive may be to establish a pseudo-independent board-one that meets the minimal judicial criteria for accepting a decision not to sue but is still dominated by those seeking its protection. Judicial review may help solve this dilemma, however, by providing a crutch upon which independent directors struggling to assert themselves and make disinterested judgments can lean. Judicial oversight fosters board independence because it enables independent directors to justify their refusal to do as management wishes (reject the suit) on the grounds that a reviewing court would not accept the weak or disingenuous reasons proffered.

\section{Federal Frustration: When is the Burks Test Met?}

Burks announced that a decision to terminate derivative litigation may not be made where it frustrates a federal policy, ${ }_{1}^{150}$ but then cautiously applied this principle, determining that a decision to terminate was not in principle inconsistent with the Investment Company Act. ${ }^{151}$ Because the Second Circuit had found precisely such a conflict and had reached the sweeping conclusion that the statutory scheme of the Investment Company Act implied "that the statutorily disinterested directors of a registered investment company were never meant to have the final word in determining whether it is in the best interest of a mutual fund to press claims against [insiders]," 152 the Supreme Court's reversal might seem 
to suggest that the Court will only rarely find an inconsistency between the decision not to sue and a federal policy. This, however, would be an oversimple interpretation, and would overlook the Court's sensible view of the policies underlying the Investment Company Act.

1s the Court explicitly recognized, the Investment Company Act places its principal reliance on independent directors, rather than on direct shareholder democracy or administrative agency oversight. ${ }^{133}$ Not only does the Act require that forty percent of a fund's board be composed of independent outside directors ${ }^{154}$ (and in some circumstances dictate that a majority be independent ${ }^{153}$ ), but it assigns specific duties to these independent directors and thus takes them away from the discretion of the board as a whole. ${ }^{156}$

As with Sherlock Holmes's dog that did not bark in the night, what is most important in this context is what the Act does not do. Not only did Congress reject a proposal made by the SEC to require court approval before a fund settles claims against insiders, ${ }^{137}$ but the Act also contains a clear negative pregnant: section 36(b) of the Act, added in 1970, in effect denies the board power to terminate derivative litigation challenging a breach of fiduciary duty with respect to the investment adviser's fees. ${ }^{158}$ The narrowness of this prohibition inevitably suggests that the independent members of the board retained the power to terminate other forms of derivative litigation. Indeed, given the importance attached by the Act to independent directors, it could be argued that a state rule (such as that in Maldonado II) denying the independent directors of a mutual fund the authority to terminate derivative litigation would itself conflict with the Act.

The position of the Second Circuit thus seems weak, insofar as it denies power even to the independent directors of an investment company. But, by this same token, Burks does not truly signal any general reluctance to find an inconsistency between federal policy and the decision not to sue. Other federal securities statutes contain policies quite different from those of the Investment Company Act and, in particular, rely to a greater extent on private litigation for their enforcement. ${ }^{159}$ Thus, it is necessary to avoid overgeneralizations and examine the specific policies underlying a statutory provision.

This Article attempts, therefore, to survey arguments that might be reasonably made in the contexts most likely to arise. In so doing, it must address a question Burks never squarely faced: the meaning of "frustration". Because the Burks Court found the policy of the Investment Company Act to have been misunderstood by the Second Circuit, it did not have to consider how significant a tension can exist between state and federal policies before the latter is truly frustrated. Our premise is that in resolving this question courts should focus on

153. See Burks v. Lasker, 441 U.S. at $482-85$.

154. Investment Company Act of $1940, \S 5,15$ U.S.C. $\S 80 \mathrm{a}-10$ (a) (1976).

155. Investment Company Act of 1940, \& 5, 15 U.S.C. $\S 80 \mathrm{a}-10(\mathrm{~b})(1-3)(1976)$.

156. Investment Company Act of $1940, \S \cdot 8,15$ U.S.C. $\$ 80-15$ (c) (1976).

157. See S. 3580, 76th Cong., 3d Sess. § 33(a) (1940).

158. Investment Company Act of 1940 (as amended in 1970), § 36(b), 15 U.S.C. $\S 80 \mathrm{a}-35(\mathrm{~b})$

(2) (1976).

159. See text accompanying notes $162-99$ infra. 
the adequacy of alternative remedies to the derivative action. Can other means of enforcement adequately protect the substantive federal policy? Or does the derivative action have unique properties that make its viability critical to the policy's enforcement? Such a perspective, which already has a hint of judicial support in Judge Weinfeld's opinion in Maldonado $I,{ }^{160}$ supplies very different answers to the problem of defining frustration from those derived by simply looking at the importance of the federal policy involved. Indeed, it could reasonably be argued that precisely to the extent that express or implied causes of action do not exist under the statute setting forth the federal policy, the derivative action becomes the principal means of private enforcement and so the termination of such a derivative action becomes more, rather than less, suspect.

1. Express Federal Action. Section 16(b) of the Securities Exchange Act of 1934 provides the clearest example of this first category. ${ }^{161}$ Because the "short swing" profits recovered by this action go to the corporation, it seems fair to characterize this type of action as essentially derivative. The 1934 Act specifically authorizes the shareholder to file suit 60 days after a request is made upon the corporation (if the corporation fails to file the suit), and there thus seems little doubt that a decision not to sue by even the most independent of boards would be in direct conflict with the policy of the statute. ${ }^{162}$ Conceivably, where the applicability of section 16(b) is unclear, a decision by the board to settle such an action for less than the value of the insider's gains might be respected, if the board sought to justify it on the grounds that the litigation costs would exceed the difference in recovery. But even here, the statute's provision that the shareholder may intervene if the corporation "shall fail diligently to prosecute" ${ }_{163}$ seems to reflect a strong statutory policy giving the shareholder-plaintiff the ultimate discretion with respect to any proposed termination of the litigation.

2. Express Federal Duty. Typically, the Securities Exchange Act of 1934 does not provide or imply a private cause of action for every duty it imposes. For example, section 13(b)(2) of the Act ${ }^{164}$ requires "reporting" issuers to install and maintain a system of adequate internal accounting controls. No private cause

160. In Maldonado I, Judge Weinfeld wrote:

Plaintiff's argument also implies incorrectly that derivative actions are the sole private means of redressing violations of Section 14(a) and enforcing the Congressional poliey of protecting investors. The cause of action implied under Section 14(a), however, can also be asserted by an individual shareholder in his own behalf or as a class action on behalf of all affected shareholders and therefore the business judgment rule cannot be said to preclude private enforcement of the proxy rules.

Maldonado v. Flynn, 485 F. Supp. at 281 (footnote omitted). But see text accompanying notes 195-99 infra for a critical analysis of Judge Weinfeld's view that a class action is an adequate substitute for a derivative action.

161. Securities Exchange Act of 1934, § 16(b), 15 U.S.C. § 78p(b) (1976).

162. In Grynberg v. Farmer, [1980] Fed. Sec. L. Rep. (CCH) 997,683 (D. Colo. 1980), a federal court denied a motion to dismiss a $\$ 16$ (b) suit after finding that the special litigation committee was not independent. By implication, this suggests that the court believed a properly constituted committee could have dismissed the action, a view that we find in conflict with the statute's 60-day time limit for board action to recover the short swing profit. We disagree with the implication that an independent board would have such a power.

163. Securities Exchange Act of 1934, § 16(b), 15 U.S.C. § 78p(b) (1976).

164. Securities Exchange Act of 1934, § 13(b)(2), 15 U.S.C. $\S 78 \mathrm{~m}(\mathrm{~b})$ (1976). 
of action is expressly provided, and most commentators doubt after recent Supreme Court decisions that such a cause of action will be implied. ${ }^{165}$ The absence of a direct cause of action enhances the importance of the derivative suit as a primary means of enforcing compliance with the directors' duty to install federally mandated monitoring controls. To illustrate, consider a derivative action alleging that illegal political payoffs were made by a reporting issuer; following their disclosure, foreign governments cancelled profitable contracts, and the corporation suffered a significant loss. ${ }^{166}$ Assume further that the suit names the corporation's directors as defendants and alleges that a proximate cause of the loss was their failure to install adequate accounting controls after due notice that the absence of such controls facilitated the illegal payments. Subsequent to the commencement of the suit, three new independent directors are appointed to the board and, once constituted as a litigation committee, they decide to terminate the suit on the grounds that it is not in the corporation's best interests because it would chill outsiders' willingness to serve as directors. ${ }^{167}$

If the directors' decision is accepted, it arguably perpetuates the absence of adequate accounting controls. Other available remedies to enforce this duty will be inapplicable or inadequate in some cases. Antifraud suits for nondisclosure will be of little use if the corporation's stock value has not declined so as to provide some measure of damages. (It may have risen for reasons quite independent of, and partially offset by, the illegal conduct.) Similarly, the SEC's enforcement resources are limited, and the SEC has recently displayed a reduced interest in enforcing the Foreign Corrupt Practices Act. ${ }^{16 s}$ Thus, if the derivative

165. See Siegal, The Implication Doctrine and the Foreign Corrupt Practices Act, 79 Colum. L. Rev. 1085, 1112 (1979). Professor Schwartz expressed a similar view at the Seventh Annual Securities Regulation Institute of the University of California. [1980] 538 Sec. Reg. \& L. Rep. (BNA) D-8.

166. Federal jurisdiction might be based on diversity as well as on an established federal cause of action. Thus, even if no private right is applicable to the provisions alleged to have been violated, the court may have jurisdiction over the subject matter under some other provision of law, and it should consider the standard of conduct prescribed in the statute. For example, although a state court lacks jurisdiction to enforce the Foreign Corrupt Practices Act, it may be called upon to determine whether defendants violated public policy or acted recklessly; in making its evaluation, it should assume that federally legislated standards establish the standards of behavior expccted of the rcasonable man. In this manner, the standard of reasonableness may evolve over time as the legislature speaks or customs change, since the reasonable man does not defy the legislature's pronouncement of governing community standards. See Coffee, Beyond the Shut-Eyed Sentry: Toward a Theoretical View of Corporate Misconduct and an Effective Legal Response, 63 Va. L. Rev. 1099, 1185-90 (1977). Others have also suggested that state law's interpretation of nonspecific dutics should be guided by relevant federal standards. See L. Loss, Securities Regulation 973 (2d cd. 1961). Analogously, state courts have found that violations of the antitrust laws, which provide no state remcdy for the offending corporation against its directors in a derivative suit, still may support an action at common law. Thus, even if the statute is not itself a basis for jurisdiction, it may still set the standard of conduct. Comment, Federal Anti-Trust Law-Stockholders' Remedies for Corporate 1njury Resulting From Anti-Trust Violations: Derivative of Anti-Trust Suit and Fiduciary Duty Actions, 59 Mich. L. Rev. 904, 912-29 (1961).

167. See text accompanying note 112 supra.

168. In a recent speech, SEC Chairman Harold Williams emphasized that the Commission has exercised great caution in enforcing the Act's provisions, noting that the Commission "has not sought out violations of the accounting provisions for their own sake; indeed, we have not chosen to bring a single case under these provisions which did not also involve other violations of law." The 
suit can be terminated-without at least some judicial inquiry into the adequacy of the accounting controls - the disturbing prospect of a right without a remedy appears likely. ${ }^{169}$

3. Established Implied Causes of Action. Implied federal causes of action have been clearly established under several sections of the federal securities laws and continue to be viewed as vital to the statutory scheme of the Securities Exchange Act of 1934. The leading examples are sections 10(b) and 14(a) of that Act, which proscribe fraud in connection with securities transactions and in the solicitation of proxies, respectively. ${ }^{170}$ The policies that these implied actions protect are well known: full and fair disclosure and fair corporate suffrage. Thus, there is a sharp contrast with Burks, where an implied cause of action was not clearly established under the Investment Company Act. ${ }^{171}$ More important, the central concern of the Investment Company Act is not with violations of the duty of due care-plaintiff's basic theory in Burks-but rather with conflicts of interest. Thus, neither the statute's basic policy nor its scheme of enforcement was offended by dismissal of the Burks suit.

Conversely, since J. I. Case Co. v. Borak, ${ }^{172}$ the importance of private enforcement through the derivative suit has been recognized in the context of proxy and securities litigation. However, this policy does not necessarily extend to every case alleging a violation of either section, because direct shareholder actions under rule $10 \mathrm{~b}-5^{173}$ or rule $14 \mathrm{a}-9^{174}$ may be adequate to enforce the statute's policies. Thus, it seems important to inquire of both rules whether there

Accounting Provisions of the Foreign Corrupt Practices Act: An Analysis, [1981] Fed. Sec. L. Rep. (CCH) \ 82,811 , at 83,934 (1981). But if the Commission litigates only when other legal violations are involved, then it is in effect giving little independent significance to the Foreign Corrupt Practices Act. Hence, private enforcement through derivative actions arguably becomes an important means of enforcing the duties Congress imposed. We do not mean to suggest that the question of "frustration" should vary with the enforcement policy of each Administration, but the general lack of enforcement effort or resources over time should be relevent.

169. The prospect of a right without a remedy was used by the Court in J.I. Case Co. v. Borak, 377 U.S. 426 (1964), to justify the implication of a private cause of action as a "necessary supplement to Commission action." Id. at 432-35. While the standards for the implication of private causes of action have no doubt changed since that decision, see note 14 and text accompanying note 165 supra, it seems a far less ambitious judicial act to refuse to dismiss an action grounded on an established theory because the action was also a "necessary supplement" to public enforcement than to create a new cause of action in the first instance.

170. Although recent Supreme Court decisions have drastically cut back on implied private remedies, see note 14 supra and cases cited therein, it seems a safe prediction that neither Borak nor Superintendent of Ins. v. Bankers Life \& Cas. Co., 404 U.S. 6 (1971), which recognized private causes of action under sections 14(a) and 10(b) of the Act, respectively, will be reversed as they apply to those statutory sections. In fact, in a recent dissent from an opinion implying a private right under title IX of the Education Amendments, 20 U.S.C. \& 1681 (1976), Justice Powell, who concurred in Transamerica Mortgage Advisers, Inc. v. Lewis, 444 U.S. 11 (1979) (favoring a total reappraisal of standards for judicial implication of private causes of action and advocating a "strict intent of Congress" test) has explicitly rejected overruling Borak. Cannon v. University of Chicago, 441 U.S. 677, 735 n.6 (1979) (Powell, J., dissenting).

171. See Olson, Courts Firm Against Creation of U.S. Corporation Law, Legal Times (Wash.), Apr. 21, 1980, at 42 , col. 1 .

172. 377 U.S. 426 (1964).

173. 17 C.F.R. $\$ 240.10 \mathrm{~b}-5(1980)$.

174. 17 C.F.R. $\S 240.14 a-9(1980)$. 
are special cases where the derivative action seems uniquely capable of providing a remedy.

a. Rule 10b-5 Violations. One clear case seems to exist under rule 10b-5 where current law recognizes a right that a board termination would frustrate. In Goldberg v. Meridor, ${ }^{175}$ the Second Circuit ruled that a plaintiff stockholder states a cause of action under rule 10b-5 when he alleges that a self-dealing transaction between his corporation and its controlling parent involving the issuance of securities was unfair to the former and was made possible by the parent's domination of the subsidiary's board. Defendants had argued that since the directors of the subsidiary had intimate knowledge of all material facts of the transaction, full disclosure had occurred, and the rule's interests were therefore satisfied. ${ }^{176}$ Rejecting this view in the light of the directors' conflict of interests, the Second Circuit concluded that only disclosure of the material facts directly to the minority shareholders would suffice. ${ }^{17}$ The critical fact about Goldberg $v$. Meridor from our perspective, however, is that a minority shareholder in the subsidiary could not sue directly because he would not meet the "purchaser/ seller" test of Blue Chip. ${ }^{178}$ Thus, only the subsidiary has standing to assert the rule $10 \mathrm{~b}-5$ claim, and a board termination of a derivative suit raising such a claim effectively nullifies Goldberg's conclusion that disclosure must be given to the minority shareholders. Logically, Goldberg implies that derivative actions based on rule $10 \mathrm{~b}-5$ violations should be dismissed only when the action is against a third party or the board is otherwise independent. ${ }^{179}$

Concededly, some decisions suggest that Goldberg's logic will not be followed this far. In Lewis $v$. Anderson, ${ }^{180}$ Walt Disney Productions substituted one series of stock options for another, allegedly so as to benefit insiders at the expense of the corporation. The Ninth Circuit, however, ruled that the board's decision not to sue did not conflict with the policies underlying section $10(\mathrm{~b}){ }^{181}$ Still, the Court's reasoning in Lewis does not necessarily conflict with our analysis of Goldberg's implications, given the Lewis court's narrow view of the policy underlying section 10(b). Because the Lewis court saw that policy as one of protecting "the purity of the securities market" 182 and because the excessive compensation alleged to have resulted from the issuance of new stock options did not touch the capital markets, it concluded that no federal policy was frustrated. Although the limited scope given by Lewis to the operation of rule 10b-5

175. 567 F.2d 209 (2d Cir. 1977).

176. Defendants maintained that, under Santa Fe Indus., Inc. v. Green, 430 U.S. 462 (1977), the fairness of the transaction was beyond the court's scrutiny under rule 10b-5 and, since the board of the subsidiary was well acquainted with the parent corporation's financial condition, there could be no disclosure violation. See Goldberg v. Meridor, 567 F.2d 209, 214-18 (2d Cir. 1977).

177. Goldberg v. Meridor, 567 F.2d 209, 221 (2d Cir. 1977).

178. Blue Chip Stamps v. Manor Drug Stores, 421 U.S. 723 (1975) (plaintiff must be either a purchaser or seller of securities to maintain a cause of action under rule 10b-5).

179. See Healey v. Catalyst Recovery, Inc., 616 F.2d 641 (3d Cir. 1980); Alabama Farm Bureau Mut. Cas. Co. v. American Fidelity Life Ins. Co., 606 F.2d 602 (5th Cir. 1979).

180. 615 F,2d 778 (9th Cir. 1980).

181. Id. at $783-84$.

182. Id. at 783 (quoting Rochelle v. Marine Midland Grace Trust Co., 535 F.2d 523, 532 (9th Cir. 1976)). 
seems questionable,${ }^{183}$ the logic of the decision is simply that federal policy stops short of reaching plaintiff's allegations. Lewis thus approaches being a sub silentio holding that there is no available federal theory on which relief can be granted, rather than a decision on the scope of the business judgment defense.

Even under the logic of Lewis, it would be a quite different matter if the alleged fraud resulted in the issuance of falsified financial statements upon which public investors had relied. For example, in Kamin v. American Express Co. ${ }^{184}$ plaintiffs objected to the payment of a dividend in kind, consisting of stock that had declined in value below its cost. Sale of the stock and distribution of the proceeds would have produced the identical result to shareholders and given the corporation a sizeable tax deduction. This alternative would have reduced reported earnings but increased cash flow, thereby affecting the level of management's incentive compensation. For our purposes, however, the important point is not the conflict of interests between management and shareholders, but the significance of a board decision that arguably allows the corporation to overstate its earnings and thereby distort its financial statements as a claimed matter of business judgment. The good faith of the business judgment is largely irrelevant, because if the result is to overstate earnings, the directors are at least acting to benefit stockholders by deceiving public investors. Of course, to the exent that directors are fiduciaries for stockholders rather than for the world at large, this is exactly what one might expect them to do within the limits of the law. But it conflicts with a federal policy that places disclosure to investors above the interests of the corporation. ${ }^{185}$

Kamin thus presents a case where the underlying conduct implicates no federal policy, but the board's justification of it may-since it seems to suggest that the desire to overstate earnings supplies a legitimate reason for declining to minimize federal taxes.

b. Proxy Rule Violations. The proxy context is complicated by the tendency for the alleged securities law violations to be only tangentially related to the core theory of the case. Thus, in Abbey v. Control Data Corp. ${ }^{186}$ the Eighth Circuit concluded that the policies underlying section 14(a) were only tangentially related to a derivative action arising out of illegal payments to foreign governments, and accordingly it accepted the board's decision not to sue. Still, it would seem a mistake to generalize broadly from Abbey. The payments in Abbey were not alleged to have been made by persons who were candidates for election to the board, and this seems critical to the issue of whether a sufficient nexus existed between the federal interest and the alleged wrong.

Precedent, however, suggests that if the facts in Abbey were only marginally different the action should not have been dismissed. Although a number of

I83. In contrast to Lewis $v$. Anderson's narrow view of the scope of rule 10b-5, see Superintendent of Ins. v. Bankers Life \& Cas. Co., 404 U.S. 6 (1971) (holding that rule 10b-5 reaches "garden variety" frauds as well as those perpetrated on stock exchanges).

184. 86 Misc. 2d 809, 383 N.Y.S.2d 807 (S. Ct. 1976).

185. It appears settled that a conscious decision to violate a statute is outside the scope of the business judgment rule. Miller v. American Tel. \& Tel. Co., 507 F.2d 759 (3d Cir. 1974).

186. 603 F.2d 724 (8th Cir. 1979). 
cases have dismissed section 14(a) actions where the illegal payments were too remote from the election of the directors for the court to see the requisite causal nexus, ${ }^{187}$ an important counter-principle has been set forth in Weisberg v. Coastal States Gas Corp. ${ }^{188}$ There, plaintiff alleged a continuing "covcr-up," and the court concluded that if such allegations could be proven, they would be material to shareholders in the election of directors. Thus, the absence of involvement by the directors seeking reelection in Abbey becomes the critical distinction between it and Weisberg. A second limitation on Abbey seems apparent from Galef $v$. Alexander, ${ }^{189}$ which suggests that when the alleged nondiclosure relates to a benefit received by the directors themselves (or at least some of them), its causal relationship with the proxy solicitation will be sufficiently strong to preclude a board decision to dismiss the derivative action. ${ }^{190}$

The Galef argument has, however, a potential flaw: even if a section 14(a) violation has occurred, it does not necessarily follow that a derivative suit is the necessary or preferable means of remedying it. As Judge Weinfeld noted in Maldonado $I$, the availability of individual and class actions to challenge proxy rule violations makes it difficult to claim that the derivative action is indispensable. ${ }^{195}$ Of course, if the action were brought as a class action, the corporation, not being a party to the suit, could not exercise its business judgment to terminate it. A court may therefore fcel little sympathy for a plaintiff who elected the wrong remedy.

Still, Judge Weinfeld's argument should not be accepted too quickly. lndeed, in Galef the Second Circuit seemed to endorse the opposite conclusion:

Obviously the goal of $\S 14$ (a) that communications from management be accurate and complete as to all material facts is a vital one. Its achievement would quite clearly be frustrated if a director who was made a defendant in a derivative action for providing inadequate information in connection with a proxy solicitation were permitted to cause the dismissal of that action simply on the basis of his judgment that its pursuit was not in the best interest of the corporation. The very premises which give life to a derivative right of action to enforce $\S$ 14(a) must save it from a premature death. ${ }^{192}$

Unfortunately, although Galef states that the derivative suit is vital to the enforcement of section 14(a), it never quite explains why. But such an explanation

187. Nemo v. Allen, [1979] Fed. Sec. L. Rep. (CCH) 196,765 (S.D.N.Y. 1979); Herman v. Beretta, [1978] Fed. Sec. L. Rep. (CCH) I 96,574 (S.D.N.Y. 1978); In re Tenneco Sec. Litigation, [1978] Fed. Sec. L. Rep. (CCH) If 96,492 (S.D. Tex. 1978); Kamerman v. Pakco Cos., Ine., [1978] Fed. Sec. L. Rep. (CCH) \ 96,318 (S.D.N.Y. 1978); Limmer v. General Tel. \& Elec. Corp., [1977] Fed. Sec. L. Rep. (CCH) I 96,111 (S.D.N.Y. 1977); Lewis v. Elam, [1977] Fed. Sec. L. Rep. (CCH) 996,013 (S.D.N.Y. 1977); Levy v. Johnson, [1977] Fed. Sec. L. Rep. (CCH) \ 95,899 (S.D.N.Y. 1977).

188. 609 F.2d 650 (2d Cir. 1979). See Block and Barton, supra note 13, at 117.

189. 615 F.2d 51 (2d Cir. 1980).

190. Id. at 65-66.

191. Id. See note 160 supra.

192. Galef v. Alexander, 615 F.2d at 63-64 (emphasis added). 
can be given: at least potentially, the derivative action offers the prospect of greater deterrence than a direct action. It does so for two basic reasons overlooked by Judge Weinfeld in Maldonado $I$.

First, in direct actions, it is normally possible to indemnify the defendant directors for fines, penalties, and settlement payments unless they should have recognized that their action was illegal. In derivative actions, by contrast, such amounts may not be indemnified. ${ }^{193}$ Even though indemnification is more questionable in a direct action for liabilities imposed under the federal securities laws, contribution remains possible between the individual defendants and their corporation. ${ }^{194}$ As a result, the derivative action still generally poses a greater deterrent threat to the defendant, since he cannot as easily escape its sanctions.

Second, the economic incentives for plaintiff's counsel will frequently be stronger in derivative actions than in direct ones, particularly where nonmonetary relief is involved. Rarely will counsel in a class action be able to recover a fee from the class unless he succeeds in creating a fund, ${ }^{195}$ and even more rarely will counsel be awarded a fee from the losing party. ${ }^{196}$ In a derivative suit, however, counsel would be entitled to receive a fee from his "client," the corporation, so long as a benefit was conferred, even if the "benefit" consisted only of setting aside an improperly conducted election, enjoining a transaction, or securing a settlement that is "forward looking." 197 For example, if the court in Maldonado $I$ had nullified the election of directors and issued an injunction against further misleading proxy statements, but denied damages, it still could have awarded

193. See Model Business Corporation Act $\S 5$ [hereinafter cited as MBCA]. For an explanation of the new structure of $\S 5$, as recently amended, see Report of Committee on Corporate Laws, Changes in the Model Business Corporation Act Affecting Indemnification of Corporate Personnel, 36 Bus. Law. 99 (1980).

194. See generally Globus v. Law Research Serv., Inc., 418 F.2d 1276 (2d Cir. 1969), cert. denied, 397 U.S. 913 (1970). The status of indemnification under $\$ 14(a)$ of the Securities Exchange Act of 1934 has not yet been judicially resolved, and it can be distinguished from Globus since scienter is not a necessary element of the cause of action. Nonetheless, we doubt that a different answer will result. Still, although indemnification will probably be barred, equitable contribution among joint tortfeasors will almost certainly be allowed. See Globus v. Law Research Serv., Inc., 442 F.2d 1346 (2d Cir. 1971); Rice v. McDonnell \& Co., 442 F. Supp. 952, 954-55 (S.D.N.Y. 1977); Odette v. Shearson, Hammill \& Co., 394 F. Supp. 946, 954-59 (S.D.N.Y. 1975). Outside the securities law context, this same distinction has also been made between permissible contribution and impermissible indemnification. See Professional Beauty Supply, Inc. v. National Beauty Supply, Inc., 594 F.2d 1179, 1182-87 (8th Cir. 1979).

195. In Boeing Co. v. Van Gemert, 444 U.S. 472 (1980), the Court stated the general rule to be that "a litigant or a lawyer who recovers a common fund for the benefit of persons other than himself or his client is entitled to a reasonable attorney's fee from the fund as a whole." Id. at 478. The Court noted that the common fund "stands as well-recognized exception to the general principle that requires every litigant to bear his own attorney's fees . . . ." Id. See Sprague v. Ticonic Nat'l Bank, 307 U.S. 161 (1939). Dawson, Lawyers and Involuntary Clients: Attorney Fees From Funds, 87 Harv. L. Rev. 1597 (1974).

196. This is the so-called "American rule," to which exceptions are rarely inade. See Alyeska Pipeline Serv. Co. v. Wilderness Soc'y, 421 U.S. 240 (1975).

Irving Morris, one of the leading representative suit lawyers in the country (and plaintiff's counsel in Maldonado II) has vividly described the problem of the victorious plaintiff's counsel who has neglected to create a fund in a class action. Morris muses about the morning-after feeling of emptiness that follows a "victory" without a fund. Morris, A View of Representative Actions, Derivative and Class, From a Plaintiff's Attomey's Vantage Point, 3 Del. J. Corp. L. 273 (1978).

197. Chrysler Corp. v. Dann, 43 Del. Ch. 252, 223 A.2d 384 (Del. 1966); Rosenthal v. Burry Biscuit Corp., 42 Del. Ch. 279, 209 A.2d 459 (1949). 
a fee to counsel in a derivative suit. On the other hand, it would have had difficulty assessing a fee on the class members. Indeed, such a levy seems essentially uncollectable since most shareholders will be unaware of the existence of the suit and will resist efforts at its collection. Yet nonmonetary relief can have great importance, and will be ignored unless some means can be found to compensate the counsel who secures it. At present, the derivative action responds to this problem, but the class action does not.

To be sure, it is not in every case that the need to compensate counsel tips the balance in favor of permitting the derivative suit to proceed. In some instances, the award of interim attorney's fees in a class action can produce an equivalent result. ${ }^{198}$ To date, however, such awards have been rare and hardly overgenerous. ${ }^{199}$ Moreover, particularly in the novel case where nonpecuniary relief is a major portion of plaintiff's requested remedy, the balance should tip in favor of the derivative suit. Clearly, this resolution is a transitional one: as the law on attorneys fees changes, so may our conclusion on the centrality of the derivative suit to the enforcement of section 14(a) require reexamination. But for the present, Maldonado I seems to have missed some critical points in its assertion that class actions are an adequate substitute for the derivative suit.

4. Self-Regulatory Rules. A considerable literature once debated the question whether private causes of action could be implied for violations of stock exchange rules. ${ }^{200}$ The argument in favor, which was accepted by most commentators and not a few courts, was that often such rules were a substitute for direct federal regulation..$^{201}$ Although the issue of an implied cause of action for violations of stock exchange rules seems moribund in the wake of recent Su-

In Mills v. Electric Auto-Lite Co., 396 U.S. 375 (1970), Justice Harlan noted that the derivative suit provides the most prominent example of the award of attorney's fees where an action "docs not bring a fund into court or add to the assets of the corporation, but it does benefit the holders of the remaining shares by enhancing their value." Id. at 394.

198. E.g., Mills v. Electric Auto-Lite Co., 396 U.S. at 393-94.

199. The Court in Mills recognized the possibility that no monetary recovery would ever be produced, even though the decision represented a final judgment that the defendants had violated their legal obligations to the plaintiff class. Ordinarily such a finding will produce some fund, but in this case an arduous hearing lay ahead to establish recovery. In fact, the Court's suspicion was confirmed; no fund was ever created. Mills v. Electric Auto-Lite Co., 552 F.2d 1239 (7th Cir. 1977), cert. denied, 434 U.S. 922, reh. denied, 434 U.S. 1002 (1978). The award of an interlocutory fee, given all the work that had been done and all that had been accomplished for the class, was understandable. Still, the absence of a fund gave the Court pause, and the additional fees later awarded were mainly symbolic.

200. See Lowenfcls, Implied Liabilities Based Upon Stock Exchange Rules, 66 Colum. L. Rev. 12 (1966); Shipman, Two Current Questions Concerning Implied Private Rights of Action Under the Exchange Act: Authority of the Administrative Agency to Negate; Existence for Violation of SelfRegulatory Requirements, 17 W. Res. L. Rev. 925 (1966); Note, Private Actions As A Remedy for Violations of Stock Exchange Rules, 83 Harv. L. Rev. 825 (1970).

201. One example is found in Judge Friendly's opinion in Colonial Realty Corp. v. Bache \& Co., 358 F.2d 178, 182 (2d Cir. 1966). While rejecting a private cause for that case, Judge Friendly noted that courts must examine the particular rule to determine whether to imply a private right of action. The case is strongest when the rule imposes a duty unknown at common law. At least one commentator agrees. Suggesting that remedies be implied for violations of moderately specific requirements that are direct substitutes for SEC regulations, he concludes that doing so would serve two purposes: protecting investors and promoting reliance on self-regulators. See Shipman, supra note 200 , at $1009-10$. 
preme Court decisions, ${ }^{202}$ the case for treating such rules as a form of surrogate regulation is now much stronger, because the SEC has acquired direct supervisory authority over their adoption. Under section 19(c) of the Securities Exchange Act of 1934, the SEC may now "abrogate, add to, and delete from" the rules of a self-regulatory organization as it deems "necessary or appropriate . . . in furtherance of the purposes of [the Act]." 203 "This authority itself takes us well down the road toward meeting the test Judge Friendly set forth in Colonial Realty ${ }^{204}$ for implying a cause of action from stock exchange rules: that the rule be a substitute for federal regulation, and that it impose an explicit regulatory duty unknown to the common law. ${ }^{205}$

Of course, implied causes of action are not the focus of our concern, and Judge Friendly's test has been replaced by the more restrictive one developed by the Supreme Court. ${ }^{206}$ Our claim, however, is more modest: such rules can constitute federal policies even if they cannot give rise to a federal cause of action. The New York Stock Exchange's rule requiring audit committees for listed companies is a good example. The history of its adoption suggests strongly that the Exchange was prodded into promulgating such a rule by the threat that the Commission could impose a still tougher rule on it. ${ }^{207}$

Accordingly, consider the case of a corporation that establishes a "token" audit committee to satisfy the New York Stock Exchange. The committee seldom meets and exists as a practical matter in name only. The corporation's outside accountants are informed not to discuss matters of accounting or auditing policy with members of the committee unless authorized to do so by senior management. As a result, highly questionable accounting policies are followed, which result in an overstatement of income. ${ }^{203}$ Assume further that the misleading financial statements published by our hypothetical company result in securities law actions and liabilities. Stockholders who bear the cost of these liabilities in turn seek to hold management and the members of the "token" audit committee accountable. If even truly independent directors can simply reject such a derivative suit as not in the best interests of the corporation, a federal policy is arguably frustrated. Moreover, to the extent that neither express nor implied private federal causes of action exist by which to redress violations of stock

202. See note 14 supra; Jablon v. Dean Witter \& Co., 614 F.2d 677 (9th Cir. 1980).

203. Securities Acts Amendments of 1975, Pub. L. No. 94-29, § 16, 89 Stat. 146 (amending the Securities Exchange Act of 1934, § 19(c), 15 U.S.C. \& 78s(c) (1976)) (emphasis added).

204. Colonial Realty Corp. v. Bache \& Co., 358 F.2d 178 (2d Cir. 1966).

205. 1d. at 182 .

206. This is the "congressional intent" test applied in Touche Ross \& Co. v. Redington, 442 U.S. 560, 568 (1979), and followed in Transamerica Mortgage Advisors, Inc. v. Lewis, 444 U.S. 11, 15-16 (1979).

207. In 1976, then SEC Chairman Hills wrote to the Chairman of the New York Stock Exchange urging that the Exchange amend its listing agreement to require a listed company to have an audit committee composed primarily of outside directors. After some discussion and the apparent possibility that the Commission could itself amend the Exchange's rules to impose such a requirement, the Exchange bowed to the SEC's wishes and adopted an amendment similar to that proposed by Chairman Hills. See Sommer, The Impact of the SEC on Corporate Governance, 41 L. \& Contemp. Prob. 115, 141 (Summer 1977).

208. This scenario summarizes some of the allegations made in a newspaper article on California Life Corporation. See Wall St. J., Mar. 17, 1980, at 1, col. 1. 
exchange rules, the case for rejecting the decision not to sue is comparatively stronger than in the rule $10 \mathrm{~b}-5$ or proxy-rule cases.

We do not mean to assert that such a case may never be dismissed. For example, if new procedures have been instituted and the audit committee is properly restructured, it may then be appropriate for the litigation committee to decide not to sue. But even here, plaintiffs may have conferred a benefit on the corporation that justifies an award of attorney's fees if they brought the inadequacy of the audit committee to light or were the first to bring a legal challenge to it. $^{209}$

5. Miscellany. Several contexts remain that we might have addressed: derivative actions against directors who resist a lucrative tender offer; 210 the "going private" context; specific issues under the Foreign Corrupt Practices Act; ${ }^{211}$ and others. Our treatment does not purport to be exhaustive; rather its intent has been to expound a relatively modest thesis: the Investment Company Act context dealt with by Burks is the exception rather than the rule. In general, specific federal policies exist that are frequently inconsistent with decisions not to sue.

All this leads to the broader question, whether decisions not to sue can be overturned because they offend a federal policy outside of the federal securities law. Our answer takes us back over the terrain just covered. The key question must be whether derivative litigation is likely substantially to further and enforce the policies of the federal statute in a manner superior to other means of enforcement. Although a federal interest in a clean environment, nondiscriminatory hiring, and consumers' rights no doubt exists, we cannot say that these goals will be substantially furthered by the derivative suit. We do not mean to foreclose the possibility that derivative actions could serve to further these goals, but once again the relative advantages of direct actions under these statutes must be assessed and compared.

6. Is There a Federal Interest in an Effective Board of Directors? No federal statute or SEC rule of general applicability requires that the majority of a board be independent, that it be equipped with a specific staff, or that corporations of any size or type have an independent nominating committee for directors. Similarly, the Supreme Court has emphasized on several recent occasions that corporate governance is primarily a matter of state law.212 As the Court in Burks phrased it, "federal law in this area is largely regulatory and prohibitory in nature-it often limits the exercise of directorial power, but only rarely creates it." ${ }^{213}$

209. Under the modem rule, the plaintiff is awarded attorney's fees in a derivative action if he "causes" internal reforms, which defendants undertake subsequent to his demand; a judgment or a formal settlement is not essential so long as the court finds that the action was sufficiently meritorious to have provoked the ultimate reforms or compromise. See Wechsler v. Southeastern Properties, Inc., 506 F.2d 631 (2d Cir. 1974); McDonnell Douglas Corp. v. Palley, 310 A.2d 635 (Del. 1973); Baron v. Allied Artists Pictures Corp., 395 A.2d 375 (Del. Ch. 1978); Chrysler Corp. v. Dann, 43 Del. Ch. 252, 256-57, 223 A.2d 384, 387 (Del. 1966).

210. Panter v. Marshall Field \& Co., 486 F. Supp. 1168 (N.D. Ill. 1980); Berman v. Gerber Prods. Co., 454 F. Supp. 1310 (W.D. Mich. 1978). But see Lipton, supra note 17.

211. See Maher v. Zapata Corp., 490 F. Supp. 348, 349 (S.D. Tex. 1980).

212. See Burks v. Lasker, 441 U.S. 471 (1979); Cort v. Ash, 422 U.S. 66, 84-85 (1975).

213. Burks v. Lasker, 441 U.S. at 478. 
Nonetheless, in the case of "reporting" corporations there is arguably a federal interest in an effective board. The federal interest does not necessarily require structural reform (such as a nominating committee or a staff), nor is it associated with any particular substantive decision. What is required is not a correct decision, but rather a correctly reached decision, one that evidences reasonable monitoring by the board of managerial disclosures. The SEC seems to have expressed such a conclusion in its Stirling Homex staff report, ${ }^{214}$ in its testimony before Congress, ${ }^{215}$ in its new requirement that directors sign the corporation's Annual Report on Form 10-K, ${ }^{216}$ and in its consent decrees, which with increasing frequency have responded to deficiencies in corporate disclosure by instituting additional monitoring controls, by disqualifying certain corporate officials, and by revising the composition of the board. ${ }^{217}$

During the 1970's, the Commission attempted to formulate a set of standards for the outside director. ${ }^{218}$ The project was abandoned when the complexity of the task became apparent, but such an attempt, even if ultimately infeasible, illustrates the Commission's view that an effective board is necessary for adequate disclosure. Indeed, the Commission found after its improper-payments investigations that a breakdown in internal corporate controls and accountability was the universal common denominator in such cases. ${ }^{219}$

Still, on several occasions, federal courts have recently declined to accept the Commission's view as to the reach of the federal securities laws. ${ }^{20}$ Thus, in considering this asserted federal interest, courts may for the present feel controlled by decisions, such as Santa Fe Industries, Inc. v. Green ${ }^{211}$ that declined to interfere with the board's judgment if it satisfies the state law standard. Cer-

214. SEC, Report of Investigation in the Matter of Stirling Homex Corporation Relating to Activities of the Board of Directors of Stirling Homex Corporation, Release No. 39-11516 (July 16, 1975), [1975-1976 Transfer Binder] Fed. Sec. L. Rep. (CCH) \ 80,219.

215. Report of the Securities \& Exchange Commission on Questionable \& Illegal Corporate Payments \& Practices, submitted to the Senate Banking, Housing \& Urban Affairs Committee, 1976.

216. Under Securities Act Release No. 6231, 20 SEC Docket 1058 (1980), a majority of a registrant's directors must sign its Annual Report on Form 10-K with respect to all fiscal years ending after December 15, 1980. Previously, only the principal executive, financial, and accounting officers were required to sign Form 10-K. Behind this new signature requirement seems to lie an attempt by the SEC to establish an implicit duty of director diligence, since under section 18(a) of the Securities Exchange Act of 1934, those "who make or cause to be made any statement in any application, report, or document filed" with the SEC that is materially misleading are liable to investors who rely thereon, unless they can establish a good faith defense. Securities Exchange Act of 1934, § 18(a), 15 U.S.C. § 78r(a) (1976). See also Securities Act Release No. 6176, 19 SEC Docket $186(1980)$.

217. See SEC v. Mattel, Inc., [1974] Fed. Sec. L. Rep. (CCH) I 94,754 (D.D.C. 1974); Weiss \& Schwartz, Using Disclosure to Activate the Board of Directors, in Corporations at the Crossroads 127 nn.69-71 (D. DeMott ed. 1980).

218. Weiss \& Schwartz, supra note 217 , at 125 n.61.

219. See note 215 supra.

220. The Supreme Court has disagreed with the Commission as to the meaning of the key term "security," United Housing Foundation, Inc. v. Forman, 421 U.S. 837, 847-58, 858 n.25 (1975); International Bhd. of Teamsters v. Daniel, 439 U.S. 551 (1979), the elements of a claim under the anti-fraud rules, Aaron v. SEC, 446 U.S. 680 (1980); Emst \& Emst v. Hochfelder, 425 U.S. 185 (1976), and the scope of the insider trading restriction, Chiarella v. United States, 445 U.S. 222 (1980).

221. 430 U.S. 462 (1977). 
tainly, this is the pattern suggested by Lewis v. Anderson ${ }^{222}$ and Abbey v. Control Data Corporation. ${ }^{23}$ Still, the federal interest here described does not necessarily invade the zone of regulatory autonomy over corporate behavior, which the Supreme Court has given the states in its recent decisions. State law universally requires that the body deciding not to sue be independent. But state law generally defines this concept narrowly, requiring only that there be no direct domination by the defendants and no financial interest in the outcome. ${ }^{224}$ The federal interest might require a more rigorous standard, under which the board is shown to have effectively reviewed at least those decisions that affected the quality of corporate disclosure. This is no more than the theory the SEC adopted in its Stirling Homex report, when it took the outside directors to task for not doing so. ${ }^{223}$ Accordingly, the judicial inquiry undertaken by a federal court need not rely exclusively on the definition of independence under prevailing state law, but might focus on the directors' actual involvement in the process, their access to information, their relationship with counsel, and the general adequacy of the investigative procedures followed. Such a standard does not conflict with state policies because it never denies directors the substantive power to terminate, but only superimposes a stricter procedural requirement of care and attention.

The short-term prospects for such a theory are admittedly not bright. But pendulum swings have characterized this area of federal law, and if the consequence of recent decisions is to immunize egregious behavior, federal courts may find it easier to discern such a federal interest than to reject the independence of the board - an approach that involves state law issues.

$$
* * *
$$

In summary, the board's capacity to reject a derivative suit exists in potential tension with a variety of state and federal policies. On policy grounds, the board's decision not to sue is not entitled to the same degree of judicial independence as the ordinary business judgment, which in its typical form is predictive, irreversible, and relatively unreviewable. Still, if we are to encourage the development of independent boards, a middle ground between Maldonado $I$ and Maldonado II would make more sense than the polar position taken in either case. We now turn to the formulation of such a position.

\section{The Need for Legislative Reform: A Policy Evaluation and Proposed Model Statute}

The common law approach has its inevitable limits. The vague standard of fiduciary duty cannot easily give rise to prophylactic rules, "bright line" tests, or detailed procedures by which to achieve an appropriate balancing of the pub- 
lic's interest in an accountable management and the corporation's interest in terminating litigation truly injurious to it. ${ }^{226}$ The problem of defining an "independent board" provides an effective illustration of these deficiencies in the ad hoc approach of the common law. Ideally, the "independent board" might be defined in terms of objective characteristics: a majority of nonmanagement directors, an independent nominating committee, adequate staff, and the absence of a controlling stockholder. Such a definition is, of course, legislatively possible, but inevitably the judiciary's reach here must exceed its grasp. Although a court can recognize that such characteristics make a board "independent," it cannot declare that a board lacking them is necessarily passive or servile. As a result, it must judge a board in moral terms, looking for some special fact showing the absence of good faith. Because good faith in turn tends to lie in the eye of the beholder, a case law founded on it will both lack certainty and tend towards conservatism, as the court must virtually discredit the board's integrity in order to reject its judgment. ${ }^{227}$ Ultimately, the language of fiduciary-duty analysis leaves the court able at most to deal with instances of actual bias, yet impotent when faced with the subtler problems of structural bias that inhere in a corporate structure under which top management chooses, and frequently removes, directors. ${ }^{228}$

Thus, we are led to the need for a statutory solution, which would substitute a legislative definition of independence for case-by-case judgments. However, having started down the road toward a legislative rescue of the derivative suit, we found it impossible to deal only with the issue of the board's decision not to sue. Other issues must also be faced if the derivative suit is to have more than a nuisance value. Although these issues have been individually addressed by others, an integrated treatment of the policy issues surrounding the derivative action has not been attempted in a number of years. ${ }^{229}$ But with the recent curtailment of private actions under the federal securities laws, ${ }^{230}$ such a wide-

226. Much this same point has been made by Professor Marvin Chirelstein in a related context: My own view is that the development of adequate fairness standards . . . is never likely to result from a process of case-by-case, common-law decision-making. The problems are complicated, and in most instances the best solutions lie beyond the competence of courts acting under a vague and general standard of fiduciary duty. . . . What is needed, therefore, is detailed and specific legislation based on an analysis of recurring problems.

Speech by Marvin A. Chirelstein, Legislative Solutions for Fiduciary Problems, American Enterprise Institute (June 1976).

227. The language of fiduciary-duty analysis is inherently pejorative and stigmatizing. On occasion-and Swenson v. Thibaut, 39 N.C. App. 77, 250 S.E.2d 279 (1978), see notes 87-89 and accompanying text supra, supplies an example - the facts will be egregious enough for the court to invoke the language. But im the majority of cases the court will shrink from such rhetoric even if it believes the directors behaved imprudently.

228. For statistics on the prevalence of appointment and removal of board members by the chief executive officer, see Note, supra note 13, at 619-22 \& nn.98-109.

229. Probably, the last thorough assessments of the derivative action from a policy perspective were Dykstra, supra note 5; Block, Current Critical Points in Stockholder Litigation, 62 Nw. U.L. Rev. 181 (1967); and Homstein, The Shareholder's Derivative Suit in the United States, $1967 \mathrm{~J}$. Bus. L. 282. Since these articles (all published in 1967), the attention of commentators has chiefly focused on securities litigation as a means toward corporate accountability. But with the restriction of these actions, the time has come for a serious reexamination of the derivative action.

230. See cases cited in note 14 supra. 
angle examination of the derivative action seems to us increasingly necessary. We have, therefore, looked afresh and borrowed from the corporation law of several jurisdictions (New York, California, and Pennsylvania), as well as the Model Business Corporation Act, to draft a model statutory provision that achieves, we believe, a fairer balancing of the interests of the plaintiff and the defendant.

What follows is a form of prepackaged legislative history for our model statute. Necessarily, our treatment of some of these issues is cursory, and reasonable disagreement is no doubt possible with virtually every position we have taken. But we doubt seriously that a coherent legislative policy toward the derivative action can be fashioned without facing the issues and balancing the trade-offs we pose.

\section{A. The Choice of Rationales: Deterrence Versus Compensation}

At the outset, we must ask the most basic questions: What can the derivative action realistically accomplish? What is its purpose? To our minds, the organizing principle around which the derivative action should be reconstructed is a deterrent one: the derivative action should serve as the principal means by which to enforce the fiduciary duties of corporate officials and to penalize the violation thereof. Of course, this may seem obvious. Yet, although a deterrent rationale for the derivative action has been occasionally recognized by courts-most notably in Diamond $v$. Oreamuno ${ }^{231}$ - it has never been the dominant rationale, and indeed some decisions appear frankly skeptical of it. ${ }^{232}$ By and large, courts have instead assumed that a compensatory rationale underlies the derivative action. ${ }^{233}$ Such a rationale may have been appropriate when the derivative action first emerged, but today the changed relationship between the shareholder and his corporation makes such a rationale seem increasingly anachronistic. In three critical respects, compensation is a goal that the derivative action can realize only imperfectly.

First, there is the problem of the constantly changing composition of the shareholders. A corporate recovery does not redress the injury to shareholders to the extent that the shareholders at the time of the injury subsequently disposed of their shares prior to the time of the recovery. To this extent, incoming shareholders receive a windfall gain. Somewhat inconsistently, the traditional theory of the derivative action both recognized and repressed this difficulty in identifying

231. 24 N.Y. 2d 494, 248 N.E.2d 910, 301 N.Y.S.2d 78 (1969). In Diamond, the New York Court of Appeals wrote that "the function of such an action . . . is not merely to compensate the plaintiff for wrongs committed by the defendant but ... 'to prevent them, by removing . . . all inducement ....." Id. at 498, 248 N.E.2d at 912,301 N.Y.S.2d at 81 (quoting Dutton v. Willner, 52 N.Y. 312, 319 (1873)) (emphasis in original).

232. The leading example of a decision skeptical of a deterrence rationale is Bangor Punta Operations, Inc., v. Bangor \& Aroostook R.R., 417 U.S. 703 (1974). The Court primarily emphasized the unjust windfall that would result if deterrence alone could justify an action. Id. at 717-18 \& n.14.

233. See Home Fire Ins. Co. v. Barber, 67 Neb. 644, 673, 93 N.W. 1024, 1035 (1903) ("It is not the function of eourts of equity to administer punishment. . . A plaintiff must recover on the strength of his own case, not on the weakness of the defendant's case."). 
the "true" victim of the fiduciary abuse. On the one hand, it accepted the baldest of legal fictions, that it was the corporation itself that was the injured party; on the other hand, it disqualified noncontemporaneous shareholders from bringing a derivative action. ${ }^{234}$ Yet, to be consistent, this latter perception of the derivative action, as intended to benefit injured shareholders, would also dictate either that the corporate recovery be reduced by the percentage of noncontemporaneous holders or that some portion of the recovery be redirected to the individual shareholders who sold in the intervening period since the time of the wrong. This does not happen. ${ }^{235}$ Instead, the traditional theory glosses over this problem by pretending that the corporation has suffered the injury. But if this legal fiction were truly believed, it should also follow that noncontemporaneous shareholders be accepted as eligible plaintiffs. ${ }^{236}$ To some degree, the anthropomorphic fallacy inherent in viewing the corporation, rather than its shareholders, as the victim is probably a necessary fiction accepted by courts in order to avoid the potentially enormous problems involved in identifying the true victims. But to concede this is also to concede that courts are accepting an obvious fiction because they are less interested in compensation than in seeing that wrongdoers do not escape sanctions. In short, the fiction of compensation serves the reality of deterrence.

234. This produces a paradox when all the shares of an injured corporation are held by noncontemporaneous shareholders: can the corporation sue even though the shareholder would not be able to? Compare Central Ry. Signal Co. v. Longden, 194 F.2d 310 (7th Cir. 1952) (corporation may institute suit in its own behalf), and Mauck v. Mading-Dugan Drug Co., 361 F. Supp. 1314 (N.D. Ill. 1973) (same), with Capitol Wine \& Spirit Corp. v. Pokrass, 277 A.D. 184, 98 N.Y.S.2d 291 (1950), aff'd mem., 302 N.Y. 734, 98 N.E.2d 704 (1951) (suit by corporation barred when shareholders lack standing). See generally Note, Corporate Incapacity to Sue Where Stockholders Would be Barred From Suing Derivatively - The Vicarious Incapacity Rule: A Public Interest Exception, 54 B.U.L. Rev. 355 (1974).

235. Courts do disqualify plaintiffs subject to personal defenses, including generally shareholders who ratified the act in question, and, possibly, their transferees. See Bloodworth v. Bloodworth, $225 \mathrm{Ga} .379,169$ S.E.2d 150 (1969); Note, supra note 234 , at 362-66. But where the corporation is permitted to sue, it is only in the rare case that the corporate recovery is diminished on account of the ineligible shareholders. Concededly, in Bangor Punta Operations, Inc. v. Bangor \& Aroostook R.R., 417 U.S. 703 (1974), the Court did preclude a suit by the corporation, but there the remaining contemporaneous shareholders constituted about $1 \%$ of the remaining shares. In cases where a majority of the shares im the corporation are still held by contemporaneous owners, we are unaware of any decisions involving public corporations that have reduced the damages allowed by the percentage of noncontemporaneous owners. Compare also Hawkins v. Mall, Inc., 444 S.W.2d 369, 387-89 (Mo. 1969), with Kullgren v. Navy Gas \& Supply Co., 112 Colo. 331, 149 P.2d 653 (1944). In a few cases where a majority of the shareholders are noncontemporaneous holders, courts have directed pro-rata recovery to the contemporaneous holders. See Joyce v. Congdon, 114 Wash. 239, 195 P. 29 (1921); Chounis v. Laing, 125 W. Va. 275, 23 S.E.2d 628 (1942); Young v. Columbia Oil Co., 110 W. Va. 364,158 S.E. 678 (1931).

236. Although the contemporaneous ownership rule is virtually the universal common law rule, some courts have found a means by which to outflank it in appropriate cases: they have characterized the wrong as a "continuing" one and thus deemed the incoming shareholder a "contemporaneous" one, eligible to bring suit. See Palmer v. Morris, 316 F.2d 649 (5th Cir. 1963); Maclary v. Pleasant Hills, Inc., 35 Del. Ch. 39, 109 A.2d 830 (1954); Forbes v. Wells Beach Casino, Inc., 307 A.2d 210 (Me. 1973); Goldie v. Yaker, 78 N.M. 485, 432 P.2d 841 (1967) (dictum). We suspect that in deciding whether the wrong was a continuing one courts have often looked to whether a culpable defendant would otherwise go unpunished; if so, considerations of deterrence reenter through the back door although barred at the front. 
A second problem with a compensatory rationale is that the corporate injury resulting from a fiduciary breach is not necessarily the same as the injury suffered by shareholders. Even assuming an efficient securities market that automatically translates any injury suffered by the corporation into a decline in its share values, ${ }^{237}$ it is still plausible that the stockholders' aggregate loss will exceed that of the corporation - basically because the events will be seen by the marketplace as creating a risk of repetition. For example, a self-dealing transaction between a controlling shareholder and his corporation may result in a hypothetical loss of $\$ 1$ million to the corporation. But to the extent that this signals to the marketplace that the shareholders in the corporation are vulnerable to such abuse, the market would rationally discount the aggregate value of the corporation's shares by more than $\$ 1$ million in anticipation of future abuses. In short, for legal purposes, the corporation's loss is a historical concept, measured by accounting conventions and limited to injuries that have actually occurred; in contrast, the shareholder's loss may be greater, because in a securities market that discounts future possibilities, predictions of future loss are immediately converted into a present decline in share values. ${ }^{238}$

Conversely, a corporate recovery does not necessarily produce a corresponding benefit to shareholders. Where one shareholder holds a large enough block of stock to carry a control premium, the corporate recovery may disproportionately benefit his shares, and thus have a less than proportionate impact on the shares of minority shareholders. ${ }^{239}$ Alternatively, a corporate recovery may be dissipated by excess managerial remuneration. Whatever the scenario-and many are possible-compensation of shareholders does not automatically follow from a corporate recovery.

A final, and partially countervailing, problein with a compensatory rationale is that the typical recovery in a derivative action, although large in absolute terms, is seldom more than de minimis on a per share basis. In some wellknown cases, it has amounted only to a few pennies a share. ${ }^{240}$ If all the derivative suit accomplishes is the refund of a few cents per share to thousands of individual shareholders, it is difficult to conclude that such a result justifies the

237. For accessible explanations of this theory, see J. Lorie \& M. Hamilton, The Stock Market: Theories and Evidence 70-97 (1973); Note, The Efficient Capital Market Hypothesis, Economic Theory and the Regulation of the Securities Industry, 29 Stan. L. Rev. 1031 (1977).

238. Thus, for example, if an unfair self-dealing transaction between a parent corporation and a subsidiary having a minority ownership were enjoined, tbe market value of the minority's intercst logically might not rise to its value prior to the proposed transaction, since the majority has signalled its intent to deal unfairly with the minority and might achieve the same result by other means (c.g., a "going private" transaction) in the future.

239. This was clearly recognized by the California Supreme Court in Jones v. H.F. Ahmanson \& Co., 1 Cal. 3d 93, 460 P.2d 464, 81 Cal. Rptr. 592 (1969).

240. In Winkelman v. General Motors Corp., 44 F. Supp. 960 (S.D.N.Y. 1942), the three plaintiffs gained $8 \notin$ per share for the 90 shares held between them. In Hornstein v. Paramount Pictures, Inc., 22 Misc. 2d 996, 37 N.Y.S.2d 404 (Sup. Ct. 1942), aff'd mem., 266 A.D. 659, 41 N.Y.S.2d 210 (1943), aff'd per curiam, 292 N.Y. 468, 55 N.E.2d 740 (1944), defendants asserted that the five plaintiffs stood to gain $\$ 3.57, \$ 0.41, \$ 2.41, \$ 0.17$, and $\$ 0.65$ respectively. See W. Cary \& M. Eisenberg, Cases and Materials on Corporations 888 (5th ed. unabr. 1980). See also Wood Report, supra note 3, at 49-50. 
considerable drain on judicial time and court resources that the litigation of this complex form of action creates..$^{241}$ Such a recovery will be neither much noticed by the individual shareholder nor responded to by the stock market. ${ }^{242}$ Of course, this objection applies as well to many class actions. In this light, the great achievement of both class and derivative actions is not that they yield meaningful compensation, but that by aggregating such individual losses, they produce a great enough sanction to create real deterrence.

These three objections-the likelihood of share transfers between the time of the wrong and that of the recovery, the lack of congruence between corporate gains and losses and those of shareholders, and the trivial size of the typical recovery on a pro-rated basis-do not imply that compensation is an illusory or insignificant goal. But they do cast considerable doubt on its ability to serve as the central rationale of the derivative action.

In contrast, a deterrent rationale for the derivative action is not significantly affected by these problems. From a deterrent perspective, it matters less who gets the recovery than who pays it; sanctions have a role independent of their ability to make victims whole. In addition, the derivative action is in some ways naturally adapted to a deterrent rationale, principally because it harnesses private enforcement resources and focuses its penalties on the individual rather than the corporation..$^{243}$ Class actions, particularly those under the securities laws, may also accomplish this, but in several respects the derivative action is at least potentially superior as a deterrent remedy. First, the derivative action is basically unaffected by the line of recent cases that have restricted the availability of direct private causes of action. ${ }^{244}$ Second, the recovery it yields will less frequently come out of the pockets of the shareholders themselves, since their corporation will not be the principal defendant in the action, but rather a nominal plaintiff. ${ }^{245}$ Third, the derivative action can better justify an award of attorney's

241. Representative actions, including the derivative suit, place special burdens on the court because of the existence of multiple parties and appear to contribute disproportionately to judicial congestion. See Dam, Class Actions: Efficiency Compensation, Deterrence and Conflict of Interest, 4 J. Legal Stud. 47 (1975); Weinstein, Some Reflections on the "Abusiveness" of Class Actions, 58 F.R.D. 299, 300 (1973).

242. In principle, stock market values reflect discounted future earnings and thus should not respond dramatically to a nonrecurring decline in earnings caused by self-dealing in a single year, unless the self-dealing is seen as foretelling a future pattern of behavior.

243. Economists have argued that private enforcement will produce a higher level of enforcement activity than public enforcement because, as a profit maximizer, the private enforcer will respond to the prospect of high fines and damages more zealously than the public enforcer. See Landes \& Posner, The Private Enforcement of Law, 4 J. Legal Stud. 1 (1975).

The individual focus of the derivative action is also important. A fine levied against a corporation may have little deterrent impact because the expected gain from the misbehavior exceeds the penalty; yet if, through the derivative action, such a fine can be reallocated against the individual officer (who typically receives relatively little of the corporation's gain from a violation of law), the deterrent impact of the penalty may vastly increase. See Coffee, Corporate Crime and Punishment: A Non-Chicago View of the Economics of Criminal Sanctions, 17 Am. Crim. L. Rev. 419, 456-59 (1980).

244. For the cases restricting the availability of private actions, see cases cited in note 14 supra. With respect to derivative liability for a knowing or reckless violation of law, see note 250 infra.

245. For example, plaintiff's counsel in a securities class action will logically pursue the deepest pocket, which will be that of the corporation rather than that of its officers. In a settlement, 
fees in those cases where the relief is substantially nonmonetary, both because the fee comes in theory from the corporation, rather than its shareholders, and because the corporation's deep pocket provides a source for a fee that could not feasibly be levied against a sizeable class of individual shareholders. ${ }^{246}$ Finally, and perhaps most importantly, there is a sharp contrast between direct and derivative actions in the ability of the defendant to obtain indemnification: in a direct action, the defendant can obtain reimbursement from the corporation for expenses paid in a settlement and potentially even for criminal fines and civil penalties, while in a derivative action settlement expenses may not be reimbursed. ${ }^{247}$

To sharpen this contrast, consider a hypothetical securities law violation committed by a corporation. If the conduct has resulted in a fine or other penalty levied by a court or the SEC, it is still likely that this penalty will be modest in proportion to the firm's assets and income. ${ }^{248}$ Private enforcement, however, can amplify the penalty into an effective deterrent. Under the securities laws, injured private parties might be able to sue for damages of considerably greater magnitude, but increasingly, today, they face an insurmountable barrier if a private cause of action was not expressly authorized by Congress. ${ }^{249}$ On the other hand, the derivative suit plaintiff does not face such a hurdle: an allegation that a corporate official knowingly or recklessly caused the corporation to commit a violation of law, or negligently suffered it to do so, continues to state a valid

it is predictable that the lion's share of the financial contribution will come from the corporation, rather than from the individual defendants (who may control the corporate defendant). Under the common view that there is a separation between the ownership and the control of the modern public corporation, the primary sanction in these instances falls indirectly on the owners of the corporation, who may have little ability to control its behavior.

246. As noted earlier, in a class action, the plaintiff's attorney must create some fund out of which attorney's fees can be paid. But in a derivative action the test is more favorable to him: has he obtained a "substantial benefit" for the corporation? See text accompanying notes 195-97 supra.

247. Under $\S 5$ of the MBCA, the corporation may generally indemnify a corporate official against "judgments, penalties, fines, settlements and reasonable expenses" if the official acted "in good faith" and "had no reasonable cause to believe his conduct was unlawful." However, in the case of derivative actions, $\S 5$ (c) of the Act limits indemnification to "reasonable expenses," and thereby precludes indemnification of judgments or settlement expenses. Otherwise the recovery would be returned to the defendants and the result would be circular. For the recently revised tcxt of $\S 5$ and an explanation of the draftsmen's intent, see Report of Committee on Corporate Laws, Changes in the Model Business Corporation Act Affcting Indemnification of Corporate Personnel, 34 Bus. Law. 1595 (1979).

248. Punitive damages are not authorized under the federal securities laws, and although the SEC may obtain a variety of ancillary remedies, its enforcement jurisdiction does not entitle it to impose penalties under the guise of obtaining equitable relief. See SEC v. Manor Nursing Centers, Inc., 458 F.2d 1082, 1104-06 (2d Cir. 1972); SEC v. Texas Gulf Sulphur Co., 446 F.2d 1301, 1308 (2d Cir.), cert. denied, 404 U.S. 1005 (1971). Farrand, Ancillary Remedies in SEC Civil Enforccment Suits, 89 Harv. L. Rev. 1779, 1800-05 (1976).

As a general matter, the fines imposed against corporations in both civil and criminal proceedings have been low in relation to their income and assets. See Geis, Criminal Penaltics for Corporate Criminals, 8 Crim. L. Bull. 377 (1972). Our point here is not to urge more severe penalties directed at the corporation, but to argue for the relative desirability of an individual focus through the use of the derivative action.

249. See Transamerica Mortgage Advisors, Inc. v. Lewis, 444 U.S. 11 (1979); Touche Ross \& Co. v. Redington, 442 U.S. 560 (1979); Cort v. Ash, 422 U.S. 66 (1975); National Railroad Passenger Corp. v. National Ass'n of Railroad Passengers, 414 U.S. 453 (1974). 
cause of action, subject to only limited exceptions. ${ }^{250}$ Finally, even if the plaintiffs in the class action are successful, their target will typically be the corporation, whose deeper pockets make it a more inviting target than the responsible officials. Even if the individual defendants are held liable or forced to contribute to a settlement, they may still be able to obtain indemnification and so escape the brunt of the loss. ${ }^{251}$ In contrast, the derivative action provides a means of reallocating damages and penalties that are imposed on the corporation (but are likely to have only modest deterrent effect with respect to it) so that their cost falls ultimately on the parties responsible for the firm's violation. On this lesser scale, a penalty that is insignificant to the firm may be more than sufficient to deter individual officials within it. ${ }^{252}$

This argument can of course be carried too far. Because the derivative action neither imposes punitive damages nor otherwise increases its penalty to compensate for a low risk of apprehension, ${ }^{233}$ it only cancels the gain that an individual seeking to benefit at the expense of his corporation expects. If the only risk the defendant faces is the potential obligation to return the misappropriated funds, he is hardly deterred. Hence, the derivative action, standing alone, is an inadequate deterrent for predatory forms of self-dealing. But in the more typical case of conduct by which the manager seeks to benefit the corporation, but engages in a violation of law or otherwise accepts extreme risks in order to do so, the prospects for deterrence are greater because the limited gain to the individual corporate official from such conduct will not approach his potential liability. In short, due care violations typically involve little expected gain and frequently threaten enormous liabilities, and thus the potential deterrent threat posed by the derivative action in this context is significant.

The differences between deterrent and compensatory rationales come into clearest focus when one poses the hardest practical questions about derivative

250. See Coffee, supra note 166 , at 1162-90. Compare Miller v. AT\&T, 507 F. $2 \mathrm{~d} 759$ (3d Cir. 1974), with Schwartz v. Romnes, 495 F.2d 844 (2d Cir. 1974). See also Blake, The Shareholders' Role In Antitrust Enforcement, 110 U. Pa. L. Rev. 143, 170-78 (1961); Forte, Liabilities of Corporate Officials for Violations of Fiduciary Duties Concerning the Antritrust Laws, 40 Ind. L.J. 313, 319-25 (1965); Note, Stockholders' Suits and the Sherman Act, 5 Stan. L. Rev. 480, 490-91 (1953).

251. See note 244 supra.

252. Blake, supra note 250 , at 157 ; Hamilton, Corporate Criminal Liability in Texas, 47 Tex. L. Rev. 60, 75 (1968).

253. Among economists, there is a consensus that in order to deter an activity, one must raise its "expected punishment cost" to a level equal to, or in excess of, the expected gain. The "expected punishment cost" is simply the mean penalty discounted by the risk of apprehension. Thus, if the likelihood of apprehension for a fiduciary violation is only 50\%, an expected penalty of $\$ 10,000$ cannot offset an expected gain of $\$ 10,000$ since ex ante it creates an "expected punishment cost" of only $\$ 5,000$. See R. Posner, Economic Analysis of Law 167-72 (2d ed. 1977); Becker, Crime and Punishment: An Economic Approach, 76 J. Pol. Econ. 169 (1968). Absent multiple damages or other special sanctions, the compensatory ceiling on the derivative action's capacity to impose a sanction prevents it from being an effective deterrent against self-dealing (assuming that the likelihood of apprehension is well below $100 \%$ ). Of course, the defendant may incur other losses as well if he is unsuccessful (e.g., his own legal expenses, a degree of stigma, and possible loss of employment). To respond to this likely deficit in adequate deterrence, subsection (b) of our proposed statute authorizes the court to disqualify corporate officials and to grant other equitable relief. See proposed $\S 49(\mathrm{~b})$ in Appendix infra. Section 188 of the British Companies Act has long authorized a similar sanction. See Companies Act, 1948, 11 \& 12 Geo. 6, c.38, § 188, at 554. 
litigation: Should a court dismiss an otherwise meritorious derivative action if it appears that costs of litigation will exceed the likely recovery? Should a defendant be permitted to raise the defense that the crime paid, that the benefits of illegal action undertaken by him on behalf of the corporation exceeded the costs and penalties imposed on the corporation as a result? ${ }^{244}$ Should a shareholder not injured by the misconduct be denied the ability to bring a meritorious derivative action that otherwise would not be pursued? In each of these cases, a deterrent perspective tends to answer in the negative, while a compensatory rationale tends to respond in the affirmative. At the same time, these questions also illustrate how unacceptable a legal system would be that took either position and applied it in a doctrinaire fashion to answer all questions that arose. Under a pure "bounty-hunter" rationale, nothing more would be required of a plaintiff than a willingness and competence to prosecute the action. If the supposed protector of the shareholders were to force the corporation to incur costs in connection with the litigation well in excess of even the maximum possible recovery, these costs would be simply rationalized as necessary to produce adequate deterrence. Conversely, under a purely compensatory rationale, the court would be placed in the morally compromising position of having to offset the fruits of misconduct against the penalties imposed therefor and possibly to acknowledge that, despite the best efforts of the state, crime did indeed pay. Both alternatives quickly produce absurd results. ${ }^{2 s}$

Thus, a balance must be struck, and the statute here proposed recognizes that equitable constraints must be placed on the pursuit of deterrence. In general, economists have warned that reliance on private enforcement of law may lead to overenforcement. ${ }^{236}$ The derivative action presents a context in which such dangers are aggravated, because it is an exception to the "American rule," under which each party bears its own legal expenses. ${ }^{257}$ In consequence, a plaintiff may seek to conscript the corporation by means of the derivative action in order to redress alleged wrongs that are of little significance and that would not be of interest to an adversary required to bear his own expenses. Accordingly, the principle is recognized that at some point considerations of cost and corporate injury may justify termination of derivative litigation..$^{258}$ At the same time,

254. For an assessment of the law in this area, see Coffee, supra note 166, at 1213-22.

255. For example, even as advocates of a deterrent rationale, we would be disquieted by an action in which the subject corporation was forced to expend $\$ 1,000,000$ in legal expenses in order to recover $\$ 100,000$ froin a faithless fiduciary. Standing alone, the deterrent rationale is too openended and clearly needs some limits. But see note 258 infra.

256. See Landes \& Posner, supra note 243; K. Elzinga \& W. Breit, The Antitrust Penalties: A Study in Law and Economics 72-77, 84-96 (1976).

257. See Alyeska Pipeline Serv. Co. v. Wilderness Soc'y, 421 U.S. 240, 257-58 (1975) (rcaffirming the "American rule" with respect to direct actions, but acknowledging that the derivative action stood apart as an exception to it); Sprague v. Ticonic Nat'l Bank, 307 U.S. 161 (1939); see also Chrysler Corp. v. Dann, 43 Del. Ch. 252, 256-57, 223 A.2d 384, 387 (1966).

258. We do not assume, however, that simply because the costs to the corporation of securing a recovery exceed the expected recovcry, the action should be dismissed. Specific and general deterrence are generated by a successful prosecution, whether civil or criminal, and constitute a benefit to the corporation. In addition, the benefit of general deterrence may have greater value to the stockholders as a class than to the corporation, because stockholders typically hold a portfolio of securities 
however, a fundamentally deterrent orientation is inherent in the statute we propose, and the specific trade-offs between the two rationales are best discussed contextually in terms of the problems next addressed.

\section{B. A Diagnosis: What Ails the Derivative Suit?}

This Article has argued that the present state of board discretion to terminate derivative actions represents the primary threat to the derivative action's survival as an effective check on management. But, from a legislative perspective, four other general obstacles also require attention.

First, the derivative action has long placed unique procedural and standing hurdles in the path of potential plaintiffs. Although the policies underlying these barriers express justifiable concerns about the dangers of frivolous litigation and unjust enrichment, their legislative implementation has been overbroad, chilling meritorious and nonmeritorious actions alike and unnecessarily disqualifying truly injured plaintiffs.

Second, the derivative action is particularly vulnerable to the problem of collusive settlements, under which the adversaries agree to nominal relief in order to justify a substantial award of attorney's fees, the cost of which is borne not by defendants, but by the stockholders theoretically protected by the action. Judicial review alone is not adequate to deal with this problem, ${ }^{259}$ and the basic solution here advanced requires that the relationship between the litigating parties be made more adversarial.

Third, because plaintiff's counsel is effectively the true party in interest in a derivative action, it is vital that economic inducements be held out to such counsel that are at least commensurate with those available from other forms of contingent-fee litigation.

Fourth, an invisible barrier to adequate deterrence is always the possibility of judicial nullification of the law based on a sense that the potential penalties are disproportionate to the misbehavior involved. The paucity of cases imposing liability on corporate officials for violations of the duty of due care ${ }^{260}$ suggests the existence of such a phenomenon and makes advisable the establishment of a fair ceiling on the financial exposure of a corporate official adjudged liable exclusively for negligence.

Other barriers to effective deterrence could also be cited, ${ }^{261}$ but in our view the Model Business Corporation Act (MBCA) sets forth acceptable standards in

rather than a single investment in one corporation. Thus, to the extent that the general deterrent effect of a successful derivative action benefits investors as a class by demonstrating that management may be held accountable, the benefit to the corporation's shareholders transcends that to the individual corporation.

259. See text accompanying note 311 infra.

260. After examining the case law, Professor Bishop has asserted that there have been only "four . . . specimens" where directors of industrial corporations have been held liable for negligence uncomplicated by self-dealing. See Bishop, Sitting Ducks and Decoy Ducks: New Trends in the Indemnification of Corporate Directors and Officers, 77 Yale L.J. 1078, 1099-1100 (1968). Although we recognize that other candidates for this list exist, there seems no doubt that the list, as so supplemented, would still remain remarkably short today.

261. In addition to the policy issues discussed in the text, there is the innportant threshold question of choice of law. Our statute takes a compromise position on the issue of which choice of 
most of these areas. ${ }^{262}$ Thus, we have chosen to concentrate our attention on those areas where significant contrasts now exist between our proposal and the current MBCA. Each of these five areas will be examined below, and the contrasting approaches outlined.

1. Procedural and Standing Barriers. These obstacles are well known and will not be discussed in detail. They may be conveniently grouped into three categories: (1) disqualifications that apply to those whose interest in the corporation is not recognized or is deemed inadequate; (2) security for expenses provisions; and (3) the requirement that the plaintiff exhaust intracorporate remedies before suing.

The first category includes provisions that disqualify beneficial holders, holders of convertible debentures, and stockholders whose interest in the corporation was acquired subsequent to the time of the alleged wrong. Each such restriction is grounded on an arguably valid purpose, but is severely overextended when applied to all cases within the category.

law rule should govem corporate affairs: the "internal affairs" rule, under which the state of incorporation is decisive, or the modern "center of gravity" rule, which now governs in related areas of law and which might make applicable the law of the jurisdiction in which the corporation has the largest presence or on which the transaction had the greatest effect. See generally Baraf, The Foreign Corporation-A Problem in Choice-of-Law Doctrine, 33 Brooklyn L. Rev. 219 (1967); Kaplan, Foreign Corporations and Local Corporate Policy, 21 Vand. L. Rcv. 433 (1968); Latty, PseudoForeign Corporations, 65 Yale L.J. 137 (1955); Ratner \& Schwartz, The Impact of Shaffer v. Heitner on the Substantive Law of Corporations, 45 Brooklyn L. Rev. 641 (1979).

Basically, our statute accepts the Suprcme Court's statement that the rationale for the majority "internal affairs" rule lies more in the "need for a uniform and certain standard to govern the internal affairs of a corporation than on the perceived interests of the State of incorporation." Shaffer v. Heitner, 433 U.S. 186, 215 n.44. (1977). In this light, the deficiency of a "center of gravity" or similar balancing test is that it is highly uncertain in its application. However, two exceptions to the internal affairs rule are clearly justifiable: rules of judicial procedure, including those applicable to derivative actions, are the prerogative of the forum jurisdiction, and the legislature of the forum jurisdietion is entitled to classify some forcign corporations as substantially equivalent to domestic corporations because of such corporations' preponderance of contacts with the forum jurisdiction. See N.Y. Bus. Corp. Law $\S \S 1317-1320$ (McKinney 1963 \& Supp. 1980); Cal. Corp. Code $\S 2115$ (West Supp. 1980). See also Halloran \& Hammer, Section 2115 of the New California General Corporation Law - The Application of California Corporation Law to Foreign Corporations, 23 U.C.L.A. L. Rev. 1282 (1976).

Thus, to the extent that this statute's requirements are procedural, they apply to all actions commenced within the jurisdiction against both domestic and foreign corporations. However, because limitations on the business judgment deeision arguably regulate internal affairs of the corporation, our proposed statute applies this limitation only to corporations subject to the state's ability to subject them to its substantive corporate law. This includes both corporations incorporated within the state and certain other corporations, typically called "pseudo-foreign corporations," which are incorporated elsewhere but doing business predominantly within the state. It is here contemplated that the jurisdiction will have already adopted a definition of "pseudo-foreign corporation" in its corporation code, which may be incorporated by reference. If it is not, the California statute supplies an attractive model.

262. A major topic, best left outside the scope of this Article, is the ability of defendants to obtain indemnification and insurance so as to avoid sanctions. This is the other major area in corporate law where courts have adopted a "frustration of public policy" test. See Globus v. Law Research Serv., Inc., 418 F.2d 1276 (2d Cir. 1969), cert. denied, 397 U.S. 913 (1970). However, as noted earlier, see note 247 supra, $\S 5$ (b) of the MBCA substantially restricts indemnification in derivative (but not direct) actions. The MBCA does not attempt to resolve the choice of law issue discussed in note 261 supra. 
Of these restrictions, the most obviously overbroad is the exclusion of beneficial holders. Although the common law has been generous in permitting beneficial holders to bring a derivative action ${ }^{263}$ some ten states follow the current version of the MBCA and require a plaintiff to have been a shareholder of record. ${ }^{26 t}$ At a time when securities are increasingly held in the "street names" for customers by brokerage houses, this requirement seems pointless and strikingly inconsistent with the treatment of beneficial holders required by the federal proxy rules. ${ }^{265}$ In recognition of the outdated character of such a provision, a proposed change in the MBCA would permit a "beneficial owner of shares held by a nominee" to sue. ${ }^{266}$ This restricted liberalization clearly covers the broker who holds securities as a nominee, but seemingly not the bank or other institution that holds securities as a trustee. ${ }^{267}$ This is unfortunate for several reasons. The institutional trustee may have a conflict of interest because of its lending or other relationships with the corporation in question and its officials. Such a trustee has little incentive to sue in any event, and might not be able to recover expenses so incurred from the trust corpus. And beneficiaries of the same trust might disagree over the desirability of the suit and even more so over the allocation among them of expenses arising from it.

263. See Stephenson v. Landegger, 464 F.2d 133 (2d Cir.), cert. denied, 409 U.S. 1039 (1972); Arfsten v. Higby, 372 P.2d 166 (Colo. 1962); Jones v. Taylor, 348 A.2d 188 (Del. Ch. 1975); LaHue v. Keystone Inv. Co., 496 P.2d 343 (Wash. 1972). See also H. Henn, Law of Corporations \$ 361 ( 2 d ed. 1970).

264. The following 10 states require the plaintiff to be a stockholder of record or a "registered" holder: Ariz. Rev. Stat. Ann. § 10-049 (1977); Me. Rev. Stat. Ann., tit. 13-A, § 627 (1974); Mont. Code Ann. § 35-1-514 (1979); Neb. Rev. Stat. § 21-2047 (1977); N.M. Stat. Ann. § 53-11-47 (1978); R.I. Gen. Laws § 7-1.1-43.1 (1969); Wash. Rev. Code Ann. § 23A.08.460 (1969); W. Va. Code § 31-1-103 (1974); Wis. Stat. Ann. § 180.405 (West 1957); Wyo. Stat. § 17-1-141.1 (1980 Cum. Supp.). In addition, Georgia ambiguously requires that the plaintiff either "had purchased his shares or was a shareholder of record." Ga. Code Ann. § 22-615 (1977).

265. Rule 14a-2 under the Securities Exchange Act of 1934, 17 C.F.R. 240.14a-2 (1980), exempts the broker holding securities for a customer from the application of the proxy rules if the broker forwards the soliciting material to the beneficial holder and "does no more than impartially instruct the person solicited to forward a proxy. . ." 17 C.F.R. § 240.14a-2(a)(1)(iii) (1980). Under rule 452 of the New York Stock Exchange, a broker cannot, without instructions, give a proxy with respect to a matter "which may affect substantially the rights or privileges of such stock." NY Stock Exch. Guide (CCH) I 2452. Finally, rule 14a-3(d) of the proxy rules, 17 C.F.R. § 240.14a-3(d) (1980), requires issuers to supply copies of soliciting materials to brokers, banks, and other custodians in sufficient quantities for mailing to beneficial holders. The interaction among these provisions effectively ensures that the voting decision will be given to the beneficial holder (although not necessarily exercised by him).

266. The Subeommittee on Shareholders' Powers of the Committee on Corporate Laws of the American Bar Association has proposed a redrafted $\S 49$ to the Model Business Corporation Act. To date, the full Committee on Corporate Laws has not yet approved the report of the Subcommittee, which was chaired by Francis Wheat, a former SEC Commissioner. As redrafted, § 49 would require that "the plaintiff was a shareholder of record or the beneficial holder of shares held by a nominee or the holder of voting trust certificates at the time of the transaction of which he complains" or that he acquires such shares by devolution from such an owner or holder. See Subcommittee on Shareholders' Powers, Memorandum to Committee on Corporate Laws, date September 3, 1980 (on file with Columbia Law Review) [hereinafter cited as Subcommittee Report]. It should be noted that the report is both tentative and unofficial.

267. It seems difficult to consider a trustee exercising investment discretion over a portfolio of securities as a mere nominee, since the trustee's decision to sell or purchase, rather than that of the beneficiary, will goveru. 
Thus, it seems wiser to vest the decision whether to litigate in the individual holders (while still permitting the trustee to sue on their behalf). Our proposed statute does substantially this, ${ }^{268}$ but with two important restrictions. First, it recognizes that a trustor may wish to deny beneficiaries the power to bring a derivative action. ${ }^{269}$ Second, it specifies that only those holding a "substantial beneficial interest" in the trust corpus, exceeding ten percent of the value of such corpus, may bring suit, and only to the extent that it is "actuarially possible to determine the value" of such person's interest. ${ }^{270}$ The term "beneficial holder" has had little judicial interpretation, and these limitations respond to the problems that would arise if those holding remote or contingent' interests in substantial collective funds, such as pension trusts or university endowments, could seek to sue derivatively on behalf of the corporations whose securities were held by such a fund. For example, absent such a restriction on the concept of "beneficial" ownership, it is at least arguable that an individual with vested pension rights could seek to sue derivatively any of the hundred or more corporations whose shares are held by his pension trust. Similarly, the student body of a university might claim a sufficient beneficial interest in its university's endowment to support such a suit. Such scenarios, while perhaps fanciful, remind us of the economist's observation that private enforcement might lead to overenforcement and the excessive allocation of resources to the prosecution of claims having little prospect of success. ${ }^{271}$ To deal with them, a limitation on standing seems appropriate. Thus, the requirement of a "substantial beneficial interest" in the fund negates the possibility of a suit based only on vested pension benefits, and the necessity of an actuarially identifiable interest precludes the students' suit.

A more significant, and indeed pervasive, restriction on shareholder standing is the contemporaneous ownership rule, which requires the shareholder to have owned his shares at the time of the alleged wrong (or thereafter acquired them by devolution). ${ }^{272}$ Underlying this rule is an understandable policy: investors should not be able to "buy" law suits, and unjust enrichment may result if the shareholder seeking recovery bought his shares at a discounted price that already reflected the injury. Conversely, from an exclusively deterrent perspective, any qualified attorney should arguably be permitted to redress a wrong. Interestingly, the Canadian Business Corporation Act has recently eliminated the contemporaneous ownership requirement. ${ }^{273}$ Still, the rule seems deeply en-

268. See the definition of "Qualified Owner" in proposed $\S 49(a)(11)$ in Appendix infra.

269. Id. (providing that if trust instrument "expressly denies the power to commence a derivative action to such beneficiary," he shall not be deemed a "Qualified Owner").

270. Id.

271. See note 256 and accompanying text supra.

272. For an overview of this requirement, see H. Henn, supra note 263, §362; see also Bangor Punta Operations, Inc. v. Bangor \& Aroostook R.R., 417 U.S. 703 (1974).

273. Under $\S 231$ of the Canadian Business Corporation Act, not only is the contemporaneous ownership doctrine abandoned, but the court in its discretion may even permit a nonshareholder to commence a derivative action; the term "complainant" is defined to include any person (in addition to shareholders and directors) the cơur determines to be a proper plaintiff. See Can. Stat. 1974 1975 , c. 33, § 231 . 
grained within our own legal system, and thus our objection is more limited: a requirement of contemporaneous ownership is seriously overbroad. It is simply fallacious to assume that all who bought after the time of the wrong had knowledge of it or purchased at a price that fully discounted the injury. Accordingly, our proposed statute follows the pattern of the California statute, which substitutes the time of public disclosure for the time of the alleged wrong in determining whether shareholders will be denied standing. ${ }^{274}$ In addition, following a Pennsylvania statute, ${ }^{275}$ our proposal authorizes the court to permit suit by a noncontemporaneous shareholder if a substantial injustice would otherwise result.

Another overbroad exclusion is that denying holders of convertible debentures standing to bring a derivative suit. ${ }^{276}$ Again, the basic notion is understandable: the interests of equity holders and those of creditors frequently conflict, and the board cannot serve both equally in making determinations about business risks. ${ }^{27}$ Convertible debentures, however, are a hybrid security, having characteristics of both debt and equity; frequently the principal value of such a security will come from its convertibility into equity. Thus, in defining equity security, our proposed statute includes convertible debentures if they would be deemed "common stock equivalents" under generally accepted accounting principles. ${ }^{278}$ At present, Accounting Principle Board Opinion No. I5 sets forth the governing criteria. ${ }^{279}$ Such a test provides a "bright line" formula for ex-

274. See Cal. Corp. Code, $\S 800(b)(1)$ (West 1977). The California statute specifies several additional conditions: (a) there is a "strong prima facie" case in favor of the claim asserted, (b) no other action has been or is likely to be asserted, (c) the defendant would otherwise retain a gain derived from the defendant's willful breach of a fiduciary duty, and (d) the requested relief will not result in unjust enrichment. We have incorporated condition (a) in our proposed statute. See proposed $\S 49$ (c) in Appendix infra. The others appear unnecessary or, in the case of condition (c), undesirable (because it seems to permit a contemporaneous owner to sue only in a self-dealing, and not a "due care," case, where there would normally be no gain derived from negligence).

275. See Pa. Stat. Ann. tit. 15, \& 1516 (Purdon $1967 \&$ Supp. 1980). In contrast to the California statute, the Pennsylvania one does not look to the time of disclosure as a cut-off and thus approaches the broad scope of the Canadian statute, see note 272 supra. From an exclusively deterrent perspective, this may seem preferable to the California approach. We recognize, however, that the absence of a temporal cut-off would raise the spectre of inviting champerty, since in theory any plaintiff could buy one share and commence suit. Moreover, we doubt that the interests of deterrence require the total elimination of all barriers to shareholder eligibility to commence suit. The critical element from a deterrent perspective is not the shareholder, but the plaintiff's attorney, and so long as the class of eligible plaintiffs is not defined in an overly restrictive manner, it is predictable that legal "underground railroads" will develop by which eligible plaintiffs are directed to those attorneys able (and willing) to prosecute derivative actions on a contingent fee basis.

276. See Harff v. Kerkorian, 324 A.2d 215 (Del. Ch. 1974). But see Hoff v. Sprayregan, 52 F.R.D. 243 (S.D.N.Y. 1971).

277. Although others have recommended a creditor's derivative action against the solvent corporation, we are dubious for fear that such an action might chill socially desirable risktaking. Moreover, to the extent that the primary utility of the derivative action is in contesting self-dealing transactions and violations of the duty of loyalty, eligible shareholder-plaintiffs can serve as adequate proxy champions for debt holders. Traditionally, the common law has denied standing to the debt holder. See Dodge v. First Wis. Trust Co., 394 F. Supp. 1124 (E.D. Wis. 1975); Dorfman v. Chemical Bank, 56 F.R.D. 363 (S.D.N.Y. 1972). But see Note, Creditors' Derivative Suits on Behalf of Solvent Corporations, 88 Yale L.J. 1299 (1979).

278. See proposed $\S 49(a)(8)$ in Appendix infra.

279. Adopted in 1969, Accounting Principle Board Opinion No. 15 classifies debt securities as "common stock equivalents" if at the time of their issuance the debt security "has a cash yield of less than $662 / 3 \%$ of the then current bank prime interest rate." American Institute of Certified Public Accountants, APB Opinion No. 15, para. 33. 
cluding those convertible debentures that are most likely to have their principal value as debt securities, while granting standing to those whose center of gravity is likely to be an equity security.

The security for expenses bond represents still another procedural barrier that has an inherent overbreadth. Again, the underlying policy premise cannot be wholly denied: the derivative action has frequently been characterized by abuse, because plaintiff's counsel has an incentive to file nonmeritorious actions if he can thereby obtain a settlement based on the action's nuisance value. ${ }^{280}$ But as a remedy for this problem, the security for expenses statute fails adequately to distinguish between meritorious and nonmeritorious actions and thereby chills both. Although the court has discretion in setting the amount of the bond, it may be incapable of, or uninterested in, distinguishing the probable merit of the litigation at the outset. ${ }^{281}$ Thus, a more effective remedy for abusive or extortionate litigation would be a backward-looking one that invites the court to impose a penalty after it has determined the merits of the case, but not before. Accordingly, our statute denies the court power to impose a security for expenses bond, but does empower the court to award reasonable costs and expenses if an action is found to have been commenced without "reasonable cause." 282 To be evenhanded, this authority also applies to defendants, and the court is specifically authorized to award interim costs and expenses where an action is prolonged by frivolous motions, abuse of discovery, or unreasonable resistance to discovery efforts. The Supreme Court has recently upheld judicial authority to impose such an award against an attorney, ${ }^{283}$ and in the context of the derivative action the plaintiff's attorney is the more logical party on whom to focus disincentives.

A final perspective on the security for expenses bond is supplied by empirical studies reporting that motions for security by defendants have become less frequent. ${ }^{284}$ In part, this is because the sophisticated plaintiff can plead a federal cause of action, with respect to which state provisions respecting security are inapplicable. ${ }^{285}$ But even where the action is in state court, the customary countermove of the plaintiff to the defendant's request for security is to request a stay

280. For the classic statement of this view, see Wood Report, supra note 3. This study found that in the case of publicly held corporations, only $2 \%$ of derivative actions surveyed had resulted in favorable judgments, and only $6 \%$ had been settled with court approval. Another quarter of the cases had been settled in a confidential manner, suggesting that the settlement may not have been received by the injured corporation. Id. at 7, 32. But see Conard, A Behavioral Analysis of Directors' Liability for Negligence, 1972 Duke L.J. 895, 901 n.21; Hornstein, supra note 3.

281. MBCA $\S 49$ currently provides that "the corporation in whose right such action is brought shall be entitled ... to require the plaintiff or plaintiffs to give security for the reasonable expenses, including fees of attorneys, that may be incurred by it ... or . . . by other parties named as defendants for which it may become legally liable." The amount of security so required is, however, basically placed "in the discretion of the court," as is the corporation's recourse to it upon termination of the action.

282. See proposed $\S 49(\mathrm{~h})(1)$ in Appendix infra.

283. See Roadway Express, Inc. v. Piper, 100 S. Ct. 2455 (1980).

284. See Note, supra note 4 , at $50,62-65$.

285. See McClure v. Borne Chem. Co., 292 F.2d 824 (3d Cir.), cert. denied, 368 U.S. 939 (1961). 
during which it will attempt to communicate with other shareholders in order to aggregate sufficient shareholders to comply with a common statutory provision that exempts substantial shareholders from the obligation to post such a bond. ${ }^{286}$ Fearing adverse publicity from such efforts, defendants have apparently declined to request security even where the motion would be granted. In this light then, the substitution of a postdecision penalty (the award of costs) for a pretrial burden (the security bond) seems not only fairer, but more effective as well.

Two other procedural requirements are also simplified by the proposed statute: the requirement of a verified complaint is eliminated, and demand on shareholders is abolished, although demand on the board is retained. While federal rule 23.1 requires a verified complaint, ${ }^{287}$ and a tentatively proposed revision of the MBCA would also require it, ${ }^{288}$ occasions arise, as the Supreme Court has recognized, in which a qualified plaintiff in a meritorious action may be unable to meet the verification requirement because of either lack of access to the relevant facts or financial naivete. ${ }^{289}$ In view of this, the danger of vexatious or frivolous litigation is better addressed by empowering the court to award costs against the responsible attorney. Demand on shareholders is abolished, as such a requirement places both an unreasonable burden on the plaintiff and unrealistic expectations on the ability of often widely scattered shareholders to communicate or reach an expeditious or informed decision. 290 Demand on directors is a universal requirement, grounded in part on the desire to avoid unnecessary litigation and encourage intracorporate settlements. ${ }^{291}$ To some degree, decisions dealing with the demand requirement have been motivated by the court's attitude toward the question of the board's power to terminate a derivative action. ${ }^{292}$ Our proposed statute, however, severs these two questions, because the demand requirement is based on other policies as well. Thus, the fact that demand on the board is not excused by a court should not imply that the same board is sufficiently independent to be able to terminate the action.

286. See Note, supra note 4 , at $62-65$. Under $\S 49$ of the MBCA, security is not required if the stockholdings of the plaintiffs exceed $5 \%$ of the outstanding shares of the class or have a market value in excess of $\$ 25,000$.

287. Fed. R. Civ. P. 23.1 (providing that "the complaint shall be verified").

288. See Subcommittee Report, supra note 266. In justifying such a requirement, the Subcommittee on Shareholders' Powers argued that "a verification requirement might provide some marginal protection against groundless suits." Id. at 6 . We disagree. It is at least as possible that such a requirement will only dissuade the more reputable attorney, but not the "strike suit" lawyer who brings an action based on its nuisance value alone. We do not doubt that such actions are filed, but believe the award of costs against the irresponsible plaintiff's attorney is the more appropriate remedy.

289. See Surowitz v. Hilton Hotels Corp., 383 U.S. 363 (1966).

290. Several major jurisdictions now expressly reject the necessity of demand on shareholders. See Cal. Corp. Code $\$ 800(b)(2)$ (West 1976); N.Y. Bus. Corp. Law $\$$ 626(c) (McKinney 1963); N.C. Bus. Corp. Act $\S 55-55$ (b) (1973). See also Mayer v. Adams, 37 Del. Ch. 298, 141 A.2d 458 (1958).

291. See Note, supra note 49.

292. See, e.g., deHaas v. Empire Petroleum Co., 435 F.2d 1223, 1228 (10th Cir. 1970) (stating that courts "have generally been lemient in excusing demand"); Barr v. Wackman, 36 N.Y.2d 731,329 N.E.2d 180, 368 N.Y.S.2d 497 (1975) (excusing demand). 
2. Incentives to Counsel. Plaintiff's counsel is the engine that drives the derivative action. For the action to constitute an effective deterrent, counsel must be compensated on a basis at least commensurate with that applicable to class actions and other forms of contingent-fee litigation. Traditionally, the successful plaintiff's counsel in a derivative suit was compensated under a salvage-value formula, under which he would receive twenty to twenty-five percent of the first million dollars recovered and a lesser percentage thereafter. ${ }^{293}$ Such a formula is clearly inappropriate for evaluating the services of counsel in any action that is settled in substantial part on the basis of nonmonetary relief. More recently, federal courts in class-action settlement hearings have turned to a different formula, which places principal emphasis on the value of the attorney's time, computed at his normal hourly rate, and then adjusts this "lodestar figure" to reflect the risk assumed and any special skill demonstrated in the case. ${ }^{294}$ Thus, we have sought to codify these precedents and extend them to the derivative-suit context. ${ }^{295}$

The concept of an adequate incentive to plaintiff's counsel also requires that the proof of damages not be overly difficult. At one time, a series of New York cases required the plaintiff in an action alleging illegal behavior by a corporate official to prove not only that the violation of law had occurred, but also that the losses caused thereby in the form of damages and fines were not outweighed by the profits from the criminal enterprise. ${ }^{236}$ The apparent assumption here, that crime does pay unless the plaintiff can prove otherwise, is objectionable from the standpoint of public policy and also from a traditional procedural viewpoint, because it forces the plaintiff to prove facts uniquely within the knowledge of the defendant. ${ }^{297}$ Although the continuing authority of these cases is questionable, ${ }^{298}$ a clear legislative expression of the court's authority to disregard profits from criminal behavior where their recognition would frustrate public policy seems desirable from a deterrent perspective. In addition, our statute reverses the burden of proof and requires the defendant to prove any such offsets. ${ }^{299}$

3. The Nullification Problem. An additional problem, countervailing to that of providing economic inducements to plaintiff's counsel, is the danger that if penalties are elevated to a level that is disproportionate to the culpability of the

293. See Cole, Counsel Fees in Stockholders' Derivative and Class Actions-Hornstein Revisited, 6 U. Rich. L. Rev. 259 (1972); Mowrey, Attomey Fees in Securities Class Action and Derivative Suits, 3 J. Corp. L. 267 (1978).

294. See Lindy Bros. Builders, Inc. v. American Radiator \& Standard Sanitary Corp., 540 F.2d 102, 118 (3d Cir. 1976); City of Detroit v. Grinnell Corp., 495 F.2d 448 (2d Cir. 1974); Lindy Bros. Builders, Inc. v. American Radiator \& Standard Sanitary Corp., 487 F.2d 161 (3d Cir. 1973). 295. See proposed $\$ 49(f)$ in Appendix infra.

296. See Borden v. Cohen, 231 N.Y.S.2d 902 (Sup. Ct. 1962); Spinella v. Heights' Ice Corp., 62 N.Y.S.2d 263 (Sup. Ct. 1946); Note, 64 Coluin. L. Rev. 174 (1964).

297. See Coffee, supra note 166 , at 1216-17.

298. In particular, Diamond v. Oreamuno, 24 N.Y.2d 494, 301 N.Y.S.2d 78, 248 N.E.2d 910 (1969), suggests that an allegation of net loss either is not necessary or can be inferred from the stigma and loss of goodwill that corporate involvement in misconduct creates. See also Knopfler v. Bohen, 15 A.D.2d 922, 225 N.Y.S.2d 609 (1962).

299. See proposed $\$ 49$ (d) in Appendix infra. 
underlying behavior, courts and juries will refuse to enforce them. This tendency of the law to nullify extreme penalties and to distort the substantive law in an effort to avoid punishments that do not fit the crime has been much discussed in the criminal-law context, ${ }^{300}$ but only rarely in the civil law. ${ }^{301}$ Nonetheless, there is reason to believe that many of the complexities and procedural barriers that have grown up to surround the derivative action are the consequence of efforts by courts in individual cases to avoid the imposition of substantial damages on corporate officials guilty of nothing more than negligence or inattention. For example, despite universal recognition of the principle that directors owe a duty of due care to their corporations, one well-known survey found only a handful of decisions-perhaps no more than four-in which courts have actually imposed liability for negligence on the directors of a nonfinancial corporation. ${ }^{302}$ Arguably, such a generalization is an overstatement, and surely many other cases have been settled in anticipation of possible liability; but in the main, courts have proven remarkably reluctant to impose liability where no element of selfdealing or personal benefit was present. In addition, it is increasingly true that the potential liability for a due care violation, absent some statutory ceiling, may be bankrupting. ${ }^{303}$ The result is that the civil liability for conduct not involving any element of scienter or willfulness may exceed the highest authorized fine for any criminal felony. Given such disparity, it would not be surprising if courts at times reacted by softening the law, placing additional burdens on plaintiffs, or recognizing new defenses. In the long run, this reaction both distorts the substantive command of the law and undermines its deterrent threat, since such legal rules, once created, cannot be easily limited to those cases where the equitable factors favor the defendant. Thus, we propose an alternative: a statutory ceiling keyed to the financial circumstances of the individual defendant and applicable only to cases involving exclusively violations of the duty of due care. ${ }^{304}$

To implement such a proposal, legislation seems necessary, since at common law the negligent tortfeasor is liable for all damages proximately caused by his negligence. ${ }^{305}$ As a model, we have looked to the Federal Securities Code,

300. The literature in this area is vast. For a seminal article, see Michael \& Wechsler, A Rationale of the Law of Homicide Pt. 2, 37 Colum. L. Rev. 1261, 1265 (1937). See also Woodson v. North Carolina, 428 U.S. 280, 289-303 (1976) (finding death penalty to have historically produced jury nullification); Hall, Strict or Liberal Construction of Penal Statutes, 48 Harv. L. Rev. 748, 750-51 (1935).

301. But see Block \& Sidak, The Cost of Antitrust Deterrence: Why Not Hang a Price Fixer Now and Then, 68 Geo. L.J. 1131, 1134 n.20 (1980); Engel, An Approach to Corporate Social Responsibility, 32 Stan. L. Rev. 1, 43 n.141 (1979).

302. See Bishop, supra note 260 . Indeed, it seems more likely than not that in the four cases cited by Professor Bishop, the courts perceived some element of self-dealing, but declined to articulate this theme for lack of clear evidence.

303. Consider, for example, the position of an outside director of Penn Central, Lockheed, Chrysler, W.T. Grant, or another major corporation that is facing or has experienced insolvency. The financial rewards are small, and should a court ultimately find that such a director failed to exercise due care, the damages proximately caused by such negligence might be bankrupting. Indeed, the risk-averse defendant may agree to a very large settlement if the action is not dismissed at an early stage.

304. See proposed $\S 49(\mathrm{k})$ in Appendix infra.

305. A caveat is necessary here. Some decisions have found that a director's negligence, even though egregious, was not the proximate cause of the corporation's loss; through this mitigating 
which, for certain violations not involving scienter or profit to the defendant, limits the defendant's liability to the greater of $\$ 100,000$ or one percent of its gross revenues (up to a maximum of $\$ 1,000,000$ ). ${ }^{306}$ Such a measure seems equitable, ${ }^{307}$ and its corollary here is a ceiling based on the defendant's highest annual gross income during the five years preceding the verdict. However, although such a ceiling equalizes defendants of different means, it must be recognized that defendants are not necessarily equal among themselves in terms of culpability or involvement. Thus, we would grant the court discretion to set the ceiling within a range bounded by the defendant's annual gross income and his aggregate fees and compensation as a director. This latter boundary, which also has a corollary in the Federal Securities Code, ${ }^{308}$ has an obvious rationale: a director who has been negligent has not earned his compensation and should return it. The combined effect of these two boundaries on the ceiling for "due care" liability permits the court to recognize degrees of responsibility and avoid the injustice of treating unequal defendants equally.

4. The Problem of Collusion. Representative actions such as the derivative suit have a built-in conflict of interests: the economic interest of plaintiff's counsel is not in a large recovery, but in a large award of attorney's fees. To the extent that defendants can offer a settlement involving only nominal relief or a small monetary recovery, but a substantial award of fees (paid by the corporation in most instances), counsel's self-interest is in conflict with that of the class of shareholders he represents, most of whom have too small an individual interest in the litigation to give it close attention..$^{309}$

In response, federal rule 23.1 requires judicial approval of all settlements, compromises, or discontinuances, and a pending revision of the MBCA would do likewise. ${ }^{310}$ Yet, as Judge Friendly has observed, this is a weak reed on which to rely, once defendant and plaintiff's counsel have formed a coalition to advance the settlement to the court. ${ }^{311}$ Thus, to reduce the possibility of such an

finding, such decisions have avoided the imposition of otherwise enormous damages. See Bames v. Andrews, 298 F. 614 (S.D.N.Y. 1924) (L. Hand, J.). Still, such judicial escape valves are of uncertain effect, and a legislative ceiling seems preferable.

306. See ALI, Federal Securities Code $\S 1708(c)(2)(1980)$. This limit would apply, for cxample, in the case of a materially misleading corporate press release.

307. Indeed, a well-known criminal law equivalent is the "day-fine," which attempts to equalize financial penalties among defendants of unequal wealth. Under this approach, defendants convicted of the same substantive offense might each be fined 30 days' wages, which in the case of the higher-income defendant would result in a higher monetary value. See Note, Criminal ProcedureThe Use of the Fine as a Criminal Sanction in New Jersey: Some Suggested Improvements, 28 Rut. L. Rev. 1185, 1190-93 (1975).

308. See ALI, Federal Securities Code $\$ 1716$ (1980) (establishing penalty for violation of "margin rule" regulations in terms of a mnltiple of the interest paid by borrower on illegal borrowings plus certain trading losses made possible by the loan). We acknowledge that the analogy to this section was suggested to us by Professor Louis Loss, Reporter for the Federal Securities Code.

309. Examples are not hard to find in which plaintiffs' attomeys have agreed to dismiss or settle class or derivative actions in retum for little discernible relief but substantial fees to themselves. See Jamison v. Butcher \& Sherrerd, 68 F.R.D. 479 (E.D. Pa. 1975); Fistel v. Christman, 133 F. Supp. 300 (S.D.N.Y. 1955). See also Haudek, The Settlement and Dismissal of Stockholders' Actions-Part II: The Settlement, 23 Sw. L.J. 765 (1969).

310. See Subcommittee Report, supra note 266, at 11-12.

311. See Saylor v. Lindsley, 456 F.2d 896, $899-900$ (2d Cir. 1972) (Friendly, J.). 
alliance, which imposes the costs of the litigation on the shareholders, additional remedies must be found. A liberal intervention standard is a partial answer, since with adequate notice other plaintiffs' attorneys will come forward to contest an inadequate settlement. ${ }^{312}$ But two other measures seem potentially useful in preventing such an alliance, by keeping the interests of the parties fundamentally antagonistic so that settlements are the product of mutual estimates of the likely results of litigation, rather than of collusion to pass costs on to the unrepresented shareholders.

First, some minimal financial contribution must be required from the defendant who is adjudged liable or chooses to settle-in effect, there must be a corresponding floor to the ceiling placed on liability by our proposed statute. At present, such a defendant may escape financial liability in one of two recurring ways: (1) although the defendant is found to have violated a duty to the stockholders (chiefly one involving disclosure), there may be no ascertainable damages to award the corporation, ${ }^{313}$ or (2) the defendant agrees to a settlement involving only nonmonetary, therapeutic relief, but providing for a substantial payment of attorney's fees by the corporation to plaintiff's counsel. ${ }^{314}$ In both instances, defendant's defeat is a bloodless one, and the real financial loss is absorbed by the corporation. But this description in turn suggests an answer: if the attorney's fees awarded plaintiff's counsel came out of defendant's pocket rather than the corporation's, the possibility of collusive settlements would be diminished, because the contest would once again be a "zero sum" one in which plaintiff's gain is defendant's loss. This does not mean that the defendant must directly pay the plaintiff's expenses, but that when the financial contribution by the defendant is less than the proposed award of expenses, the court should exercise caution and generally refrain from approving the settlement. ${ }^{315}$ Such a resolution also answers the problem of how to generate deterrence when there is a proven violation but no apparent damages: the cost to the corporation of redressing the violation (i.e., the cost of plaintiff's counsel) represents the minimum damages for which defendant should be held accountable. Thus, at a

312. See 2 G. Hornstein, Corporation Law \& Practice $§ 724$ (1959). "Liberal" decisions have permitted plaintiffs who would otherwise be time-barred by the statute of limitations to intervene and prosecute an action. See Duncan v. National Tea Co., 14 Ill. App. 2d 280, 144 N.E.2d 77I (App. Ct. 1960). Conversely, federal decisions have generally required intervenors to be contemporaneous owners. See Elkins v. Bricker, 147 F. Supp. 609 (S.D.N.Y. 1956). This seems unnecessary, since the action will proceed in any event, and it ignores the utility of intervention as a check on collusive settlements.

313. The dilemma here is well illustrated by the subsequent history of Mills v. Electric AutoLite Co., 396 U.S. 375 (1970). Having found a disclosure violation, the Court remanded to the Seventh Circuit for assessment of damages. The circuit court found that there were none. Mills v. Electric Auto-Lite Co., 552 F.2d 1239, cert. denied, 434 U.S. 922 (1977). From a deterrent standpoint, the result is an unpunished violation. To remedy this problem, we recommend that the court impose the plaintiff's attomey's fees on the defendants. See proposed $\S 49(\mathrm{~h})(3)$ in Appendix infra.

314. It is well recognized that nonmonetary relief can justify an award of attorney's fees to plaintiffs. See Bosch v. Meeker Cooperative Light \& Power Ass'n, 257 Minn. 362, 10I N.W.2d 423 (1960); Hornstein, Legal Therapeutics: The "Salvage" Factor in Counsel Fee Awards, 69 Harv. L. Rev. 658, 663 (1956). We do not quarrel with this principle, but only point to the potential for its distortion.

315. See proposed $\S 49(\mathrm{~h})(3)$, (j)(4) in Appendix infra. 
stroke, we achieve a means of compensating counsel for obtaining often important nonmonetary relief without imposing the burden on shareholders, while also reducing defendant's ability to escape unscathed.

In rebuttal, two objections will predictably be raised. First, such a reallocation of costs will chill settlements, and, second, it is a deviation from the "American rule," that each side bears its own expenses. Both these arguments are correct as far as they go. Imposing a minimum burden on the defendant who settles will chill his urge to settle-precisely by discouraging those settlements that have the highest potential for being collusive. In addition, the derivative action has long been an exception to the American rule, ${ }^{366}$ and for good reason. Basically, it is a three-sided litigation in which one party (the corporation) is for the most part an uninvolved bystander until the time comes to pay plaintiff's fees and defendant's indemnification. Such a result should not be rationalized by reference to a rule that developed in the simpler context of two-sided litigation between active parties. In addition, the fiduciary status of the defendants makes such a proposal appropriate. It is a maxim of tort law that "danger invites rescue," and here it is the danger to the corporation that prompts the plaintiff's efforts on its behalf. Having invited those efforts, the defendant should bear their cost.

A second means of realigning the interests of the parties to reduce the potential for collusion is to give the plaintiff's counsel a strong interest in opposing indemnification of the defendants. This is most directly accomplished by making the presence or absence of indemnification payments one of the factors to be considered by the court in determining the size of the counsel fees to be awarded to plaintiff's attorney. Logically, any indemnification paid by the corporation reduces the net monetary recovery received by it, and thus such amounts should be subtracted from the recovery figure that is to be used as a base in determining counsel fees. ${ }^{317}$ Procedurally, such a proposal would require the parties to inform the court as to the amount of any indemnification paid or to be paid as a result of the litigation at the time of the settlement hearing. Absent such a provision, both parties have a mutual interest in exaggerating the size of the settlement to the court (thereby justifying judicial approval of the settlement and a high award of attorney's fees). Thereafter, post-settlement indemnification may be quietly blinked at by plaintiff's counsel as an implicit condition of the settlement. To prevent this, the trio of settlement, counsel fees, and indemnification must be recognized as an integrated issue, one that needs to be resolved in a single judicial proceeding at which the parties have a fully adversarial relationship.

5. The Board's Decision to Terminate a Derivative Action. The simplest legislative resolution of the Burks v. Lasker crisis would be to overturn the

316. See note 257 supra.

317. See Lewis v. Newman, 59 F.R.D. 525 (S.D.N.Y. 1973) (estimated indemnification expenses of $\$ 28,500$ subtracted from gross settlement of $\$ 110,000$ in determining fund generated by derivative action, and award of attorney's fees correspondingly reduced from $\$ 27,500$ to $\$ 15,000$ ). See also proposed $\S 49(j)(4)$ (advising court to consider extent to which corporate recovery will be offset by indemnification in determining of counsel fees) in Appendix infra. 
decision and abolish the defense. In support of this position, a strong argument exists that the derivative action is in principle no different from the other common form of representative action-the class action-which clearly cannot be terminated by an adverse party over the plaintiff's objection. Alternatively, the termination decision could be transferred from the board to the court-as the recently revised Canadian Business Corporation Act has in fact done. ${ }^{318}$ Such an approach both screens frivolous actions and assures greater impartiality. ${ }^{319}$

Experience, rather than logic, however, leads us to the conclusion that such solutions are unlikely to gain significant support. Moreover, we see persuasive arguments why a legislative resolution that accepts the basic thrust of Burks $v$. Lasker is indeed preferable. Three reasons lead us to this conclusion and in turn explain the structure of our proposed statutory treatment of the Burks issue.

First, the power to terminate can be used as an important incentive to encourage the trend toward independent boards. Conditioning the availability of such a defense on the existence of a board that meets specific and meaningful criteria of independence, including a requirement of majority nonmanagement directors, not only creates such an incentive, but makes it strongest for those trouble-plagued companies that might otherwise be the most resistant to the current trend. ${ }^{320}$ In contrast, abolition of the defense would leave little incentive for such "problem" corporations to install or maintain an outsider presence on their boards. In this light, a difficult trade-off must be recognized: eliminating the obstacles Burks poses for the plaintiff might result in more plaintiff victories, but less independent boards - a result that could only be described as a Pyrrhic victory for the public interest.

A second basic premise behind our approach is that the historic utility of the derivative action has been its ability to enforce the duty of loyalty, not the

318. Canadian Business Corporation Act, Can. Stat. 1974-1975, c.33, § 232. Section 232(2) creates as a precondition to the prosecution of a derivative action the requirement that "the court is satisfied that .... (c) it appears to be in the interests of the corporation or its subsidiary that the action be brought, prosecuted, defended or discontinued." Under \$ 232(i), a "complainant" must apply to the court "for leave to bring an action in the name and on behalf of a corporation," and the court is required to make the above-quoted finding before permitting it to proceed. A functionally similar approach is authorized under a California statute that permits the court to impose a securities bond if it determines that "there is no reasonable possibility that the prosecution of the cause of action . . . will benefit the corporation or its shareholders." See Cal. Corp. Code $§ 800$ (c) (West 1977).

319. Our principal reservation about the Canadian approach is that it places the burden on the plaintiff to justify the action, rather than on defendant to show a substantial business justification for its dismissal. At least the initial burden of production with respect to such a motion belongs on the defendant. Moreover, under the Canadian approach, the decision comes too early-before plaintiff has had an opportunity to obtain any discovery. In contrast, on a motion to dismiss, the court can permit some discovery, particularly with respect to the board's level of independence. Finally, the independent members of the board are likely to be far less involved in the decision under the Canadian format, since the individual defendants need not necessarily involve the corporation at all in opposing the plaintiff's application. The California statute is less subject to these objections, but the securities-for-expenses bond is vulnerable to other problems already noted, including that it may be evaded by a variety of techniques. See text accompanying note 284 supra.

320. Proxy survey data released by the SEC with respect to 1980 filings shows that the number of companies with nominating committees jumped by $31 \%$ over 1979 . Audit committees were found in $85 \%$ of all companies surveyed. In addition, the number of retained attorneys and investment bankers serving on boards decreased significantly. See Securities Exchange Act Release No. 34I75I8 (198I). 
duty of due care. Thus, rather than seeking to overturn Burks, we have sought to contain it and carve out those situations most fraught with the potential for selfdealing. Specifically, we have provided that the board may not dismiss actions involving self-dealing or transactions between the corporation and any interested "controlling person" thereof (including any parent or affiliated person, the chief executive officer, and certain others in a position to dominate corporate decisionmaking). ${ }^{321}$ This does not prohibit such transactions, but only subjects them to the normal fiduciary principles established by the courts or legislature of the jurisdiction, which principles might otherwise be rendered irrelevant by the ability of a nominally independent board to cut off judicial examination. ${ }^{322}$ Such a limitation on Burks's scope can be justified either on the grounds that the legislative policy set forth in "interested director" statutes would otherwise be frustrated or on the rationale that the existence of a controlling person is logically inconsistent with the notion of an "independent" board.

The priority we give to self-dealing cases does not mean that we have dismissed the possibility of liability based on a due care violation. Although such liability seems more likely to be effectively enforced through federal securities law actions, ${ }^{323}$ derivative actions enforcing such a duty remain likely in two contexts: (1) where there has been a substantial management transition and the incoming officers have little desire to protect their predecessors, ${ }^{324}$ and (2) where a significant decision made by the board proves disastrous and thereby either entitles a trustee to commence suit or results in the disqualification of a majority of

321. See proposed $\S \S 49(f)(5) \&(a)(3)$ in Appendix infra. Basically, this codifies the result in Clark v. Lomas \& Nettleton Financial Corp., 625 F.2d 49 (5th Cir. 1980). As a matter of legal doctrine, the existence of a "controlling" person is inconsistent with the existence of an "independent" board. Concededly, our definiton of "controlling person" is more inclusive than that of the common law to date, but this is precisely the virtue of a legislative resolution, which can adopt prophylactic rules.

322. At common law, a court may review a self-dealing transaction for faimess, notwithstanding approval by a disinterested board. Statutes in many jurisdictions have modified this rule, but generally a retrospective evaluation of faimess by a court remains possible. See Buxbaum, supra note 13, at 1124-27. See also Note, The Status of the Faimess Test Under Section 713 of the New York Business Corporation Law, 76 Colum. L. Rev. 1156 (1976). As discussed earlier, this opportunity for retrospective judicial review is lost if the board may terminate the derivative action. Thus, our proposed $\S 49(f)(5)$ is intended to reconcile state conflict-of-interest law with the body of law on dismissal of derivative actions. A limited inconsistency remains under our statute since only interested transactions involving controlling persons may not be terminated; thus, an action challenging a transaction between the corporation and an outside director could be terminated even though the transaction was unfair and voidable in principle. See proposed $\S 49(f)(5)$ in Appendix infra. We are less concerned about structural bias in this context of noncontrolling persons, but others may wish to substitute for our $\$ 49(f)(5)$ broader language covering all material self-dealing transactions.

323. Federal law has imposed substantial damages on negligent dircctors if their inattention has come within the ambit of a particular securities statute imposing liability. See Gould v. AmericanHawaiian S.S. Co., 535 F.2d 761 (3d Cir. 1976); Escott v. BarChris Constr. Corp., 283 F. Supp. 643 (S.D.N.Y. 1968). In particular, the new requirement that a majority of the directors sign the corporation's annual report on form 10-K will enforce this duty. See 20 SEC Docket 1058 (Sept. 16, 1980); Securities Act of 1933 Release 6231 (Sept. 2, 1980).

324. See Bangor Punta Operations, Inc. v. Bangor \& Areostook R.R., 417 U.S. 703 (1974), for an extreme example of this pattern. See note 235 supra. In other cases involving corporate officials who have resigned in disrepute (such as after disclosure of a substantial program of illegal payments and political payoffs), the board may be too embarrassed by the disclosures to seek to protect the former official. 
the board so that the defense cannot be invoked. ${ }^{325}$ Without attempting a survey, we suspect that most historical instances of due care liability have involved one of these fact patterns and that attempts to impose due care liability on only a minority of the board were rare prior to the recent spurt of "questionable payments" cases. ${ }^{326}$ Thus limited, the Burks rule is an inroad upon, but not the death-knell of, the derivative action.

Finally, as our third premise, we sense that what is most appealing to the corporate community in Burks, Auerbach, and their more recent progeny is the deference they pay to the principle of corporate autonomy. Collectively, these decisions can be read to say that the business of business is business, not the redressing of social wrongs or the enforcing of fiduciary duties. In a time wary of overregulation and judicial activism, the strength of such a sentiment cannot be discounted, and hence proposals for close substantive judicial review of the board's decision to dismiss are likely to be unpalatable. Thus, we have attempted to rethink the interaction between the court and the board in order to achieve a compromise that minimizes the perceived danger of judicial regulation of corporate behavior, but also strengthens the goal of corporate accountability.

Against the backdrop of these premises, limitations placed by our proposed statute on the termination of derivative actions become more understandable. First, on a structural level, we have sought to place limits on the use of the special litigation committee. Such a committee (often composed of only three outside directors and sometimes appointed to the board only after the onset of the litigation) is too easily tamed and held hostage, either by explicit agreement or (as is more likely) by the expectations of the rest of the board. A critical mass level of independence is necessary before a board becomes its own master, rather than merely the buffer for management. On the other hand, a smaller, more intimate body, such as a board committee, may be able to conduct a more candid and fuller inquiry. To strike a balance between these two considerations, we have provided that a majority of the board must be independent, but permitted the investigation to be conducted by a committee. ${ }^{327}$ Ultimately, a majority of the independent directors must reject the suit for the court to grant the board's motion. ${ }^{328}$

One other limitation deserves special mention. We require that counsel advising the board be similarly independent. This disqualifies not only the corporation's house counsel and any outside counsel regularly in the employ of the corporation, but also special counsel who has served the independent directors within the prior three years. ${ }^{329}$ This prevents counsel from anticipating future

325. See, e.g., DePinto v. Provident Security Life lns. Co., 374 F.2d 37 (9th Cir. 1967); Selheimer v. Manganese Corp. of America, 423 Pa. 563, 224 A.2d 634 (1966).

326. See cases cited at note 57 supra.

327. See proposed $\S 49(f)(2)$ in Appendix infra.

328. See proposed $\S 49(f)(1)$, (3) in Appendix infra.

329. See proposed $\S 49(\mathrm{a})(12)$ in Appendix infra (requiring special counsel to meet same standard as independent director). Admittedly, some incentive for counsel to be predisposed towards terminating the action remains: by gaining a reputation as "friendly," such a counsel might secure additional appointments as special counsel for other corporations, while a "tough" counsel may never again be invited to so serve. If such a pattern develops (and it has not to this point), the appropriate solution might be to interpret such continued employment as a violation of the attorney's etbical obligation to avoid an appearance of impropriety. 
employment if it delivers the desired advice. We anticipate the rejoinder that such a prophylactic rule is inefficient both because it ignores the need for trust and confidence to develop between the independent directors and their counsel, and because the complexity of some corporate structures requires a substantial learning period before counsel is familiar with all the relevant background facts. Nonetheless, we sense that the appearance of an impropriety surrounds a situation in which the same counsel repeatedly advises a committee of directors that it may terminate a derivative action.

Our second major proposed limitation is operational rather than structural: the board must advance "a substantial business judgment independent of the merits of the litigation" ${ }^{330}$ to justify termination. "Substantial," of course, means more than "colorable" or "arguable," but it does not require the board to meet a "preponderance of the evidence" test. By insisting that the justification for termination be "independent of the merits of the litigation, this formulation recognizes the validity of both Vice Chancellor Hartnett's statement in Maldonado II, that in "our system of law, courts and not litigants should decide the merits of litigation," ${ }^{331}$ and the argument of Auerbach v. Bennett ${ }^{322}$ and subsequent decisions, that there may be more important corporate interests at stake than securing a financial recovery. The court then remains free to reject the board's justification if it finds that either (a) it is not "substantial," (b) it was not advanced "in good faith," (c) the justification is "outweighed by the probable recovery or other relief likely to result from the litigation," or (d) the justiification "frustrates" public policy. ${ }^{333}$ This negative phrasing, which requires the court to make contrary findings before it overrules the board, is intended to restrain the court from lightly substituting its own judgment for that of the board.

In effect, although this standard of review resembles the traditional "substantial evidence" standard employed by courts in reviewing the determinations of administrative agencies, ${ }^{334}$ it differs by providing the court several bases upon which to reject a decision that has a substantial business justification. Still, our formula does not require the board to demonstrate the cogency of its reasons by a preponderance of the evidence, and thus it may disappoint proponents of a more aggressively substantive style of judicial review. Our reasons for disdaining the path of judicial activism therefore require explanation. Despite our analogy to administrative law, we are doubtful that courts are entitled to intervene directly in the decisionmaking of private autonomous bodies, such as the corporation, to the

330. See proposed $\S 49(\mathrm{f})(4)$ in Appendix infra.

331. Maldonado v. Flynn, 413 A.2d 1251, 1263 (Del. Ch. 1980), rev'd and remanded sub nom. Zapata Corp. v. Maldonado, No. 113, 1980 (Del. May 13, 1981).

332. 47 N.Y.2d 619, 630, 393 N.E.2d 994, 1000, 419 N.Y.S.2d 920, 926 (1979).

333. See proposed $\S 49(f)(4)$ in Appendix infra.

334. On the meaning of "substantial evidence," see Consolidated Edison Co. v. NLRB, 305 U.S. 197, 229 (1938) ("such relevant evidence as a reasonable mind might accept as adequate to support a conclusion"). We understand that such a standard is easily satisfied and so have supplemented it by providing three bases for rejecting the justification. 
same extent as they have in recent years in public agency decisionmaking. ${ }^{335}$ To begin with, standards for judicial intervention are less apparent because the corporate charter and the state's incorporation statute hardly provide guideposts for judicial review comparable to the organic statute under which most administrative agencies are established and managed. Not only is a legislative definition of purpose lacking in the case of the corporation, but corporate managers regularly pursue diverse ends, not all of which can be described as "profit-maximizing." 336

If we thus seem to be accepting the statement in Auerbach v. Bennett that there is no "objective standard by which the correctness of every corporate decision may be measured," "${ }^{337}$ we do not agree that the implications of such a statement preclude close judicial review of board decisions. Rather, it should change the nature and character of such review. Thus, we contemplate a form of review that is less substantive and more therapeutic in orientation-one that seeks less to measure the correctness of the result than to inquire, raise alternative possibilities, and engage in a dialogue with the decisionmaker. ${ }^{338}$ ln so doing, judicial review should not replace the decisionmaker (here, the board), but rather activate it. Such a model resembles one well known to students of both administrative ${ }^{339}$ and constitutional ${ }^{340}$ law as one in which the court "re-

335. See generally $1 \mathrm{~K}$. Davis, Administrative Law Treatise $\S 6: 1$ (2d ed. 1978) (surveying judicial innovations in review of agency rule-making during 1970's); see also Sive, Some Thoughts of an Environmental Lawyer in the Wilderness of Administrative Law, 70 Colum. L. Rev. 612, 614-19 (1970) (advocating judicial activism in review of agency determinations).

336. See, e.g. Herald Co. v. Seawell, 472 F.2d 1081, 1091, 1094-95 (10th Cir. 1972) (corporation may have duties to public and employees transcending duty of profit-maximization to shareholders).

337. 47 N.Y.2d 619, 630, 393 N.E.2d 994, 1000, 419 N.Y.S.2d 920, 926 (1979).

338. In the terms of a distinction offered by Bruce Ackerman and William Hassler, we suggest that judicial review in this area should be "agenda forcing" rather than "solution forcing" and should be governed by what they term the "principle of full inquiry"-i.e., requiring the fullest possible inquiry into competing options. See Ackerman \& Hassler, Beyond the New Deal: Coal and the Clean Air Act, 89 Yale L.J. 1466, 1556-59 (1980). On the significance of placing a matter on an organization's "agenda," see K. Arrow, The Limits of Organization 45-59 (1974).

339. This model for the appropriate interaction between the court and the board is patterned after the rule developed in SEC v. Chenery Corp., 318 U.S. 80 (1943). See also Scenic Hudson Preservation Conf. v. Federal Power Comm'n, 354 F.2d 608, 620-25 (2d Cir. 1965). In Chenery, the Court held that if a matter is given to the discretion of an agency, but the reasons for the agency's action appear inadequate, the court may remand the matter for further consideration in order to induce the agency to refine and develop its own analysis. We are aware that subsequent to Chenery more activist models of judicial review of agency action have emerged, see, e.g., Citizens to Preserve Overton Park, Inc. v. Volpe, 401 U.S. 402 (1971), but we feel it necessary to resist the normal urge to carry the familiar legal doctrines of one area of law over into another, because the differences between a public agency and a private body are significant, and the dangers of judicial overregulation real.

We anticipate the rejoinder from some academic colleagues that such a posture of judicial restraint will only produce manufactured responses prepared for the independent directors by counsel whose real loyalty is to management. This danger is real, and thus we have insisted on a rigorous definition of "Special Counsel." See text accompanying note 329 supra. However, even though instances in which the board committee has determined to sue (i.e., has declined to interpose a business judgment defense) are still conspicuous by their absence, instances are likely in which the board committee will signal to defendant corporate officials their reluctance or unwillingness to interpose the defense and thereby force a favorable settlement for plaintiffs. There is evidence that board committees that are independent will today take action against corporate insiders on some occasions. See Bauer, Why Big Business Is Firing the Boss, N.Y. Times, Mar. 8, 1981, § 6 (Magazine), at 22, 84 (citing case examples). 
mands" issues to the agcncy or legislature for further consideration.

Here, this approach is especially appealing because by employing it, the court may substantially alter the balance of powcr between the board and senior management in favor of the former. So long as the board is represented by a truly independent special counsel and includes a majority of independent directors, such judicial attention may help crystallize a sense of self-awareness that in the last analysis is a far more important objective than the determination of liability in a particular case. Under this middle course, the court could indicate that the reasons given to support a decision not to sue were either partially invalid, incomplete, or insufficiently articulated; but, rather than deny defendants' motion to dismiss, it would ask for clarification. A role might also be created for plaintiff's counsel in this process, and the award of counsel fees to such attorneys would be justified if the result of the dialogue between the board and the court were a significant change in corporate policies or practices. ${ }^{\text {WI }}$

\section{ConcLusion}

Our diagnosis of the derivative action suggests that there are three distinct barriers, each requiring a different response, before the action can serve as an effective deterrent.

First, the ability of even a truly independent board to terminate an action plainly means that meritorious cases will sometimes be aborted. Although one may wish that recent case law could be reversed, the most realistic line of defense in our judgment is to confine the board's power to cases not involving material self-dealing. If cases involving breaches of the duty of loyalty are so excluded, then the historic role of the derivative action is not jeopardized, even if its potential for expansion is thereby eclipsed. As we have suggested, such a compromise is consistent with the weight of the case law.

Second, the adversaries themselves may not be relied upon to discount the probable outcome of the case in their settlement negotiations. Because the con-

340. One example of this process occurs when the court "narrowly construes" federal statutes to avoid broad delegations, thus finding administrative action unauthorized as a statutory matter, rather than holding the statute unconstitutional. See L. Tribe, American Constitutional Law \$ 5-17, at 288-89 \& n. 14 (1978). A well known case employing this procedure is Kent v. Dulles, 357 U.S. 116 (1958), in which the Court read a passport control statute namowly and denied the Secrctary of State the authority to withhold passports on the basis of beliefs or associations, emphasizing that the right to travel is an aspect of constitutionally protected liberty. Consequently, any limit on the right must be pursuant to the lawmaking functions of Congress; and if that power is delegated it must be by adequately articulated standards. In effect the Court was telling Congress that it could limit the right to travel only by means of a statute that stated a compelling reason so that the limitation would pass the Court's strict-scrutiny test. This is viewed by commentators as a remand to the legislature. See G. Gunther, Constitutional Law, Cases and Materials 1675-76 \& n.1 (10th ed. 1980).

341. Traditionally, counsel need not win a judgment or even a settlement to be entitled to an award of legal fees. Rather, the criterion has been whether plaintiff "caused" a benefit, and causation has been inferred when the claim raised was "meritorious" and the corporation took aetion on its own in the wake of plaintiff's demand. See Chrysler Corp. v. Dann, 43 Del. Ch. 252, 223 A.2d 384, 387 (Del. 1966). 
test is not a "zero sum" one, the problem of collusive settlements requires that we realign the incentives for both parties in order to reduce the current pressure to settle. By requiring the defendant to contribute at least the amount of plaintiff's expenses to any settlement and by giving a plaintiff an incentive to contest indemnification, our statute forces the parties into a more adversarial posture. Undoubtedly, both plaintiff and defendant will resist this proposal, but the public interest may lie in their being induced to fight rather than settle.

Finally, if the derivative action is ever to deal effectively with the duty of care, the current "all or nothing" choice confronting the court must be changed, or the present pattern of high rhetoric and low liability will predictably persist. We have suggested that the variance of possible outcomes be reduced by imposing a ceiling on liability after litigation (for due care violations) and a floor on the expected financial contribution required of settling defendants. This floorceiling limitation on exposure to recovery is consistent with recent thinking among criminal law reformers that punishment should be "fair and certain"reduced in its severity, but increased in its probability. ${ }^{342}$

Others will of course challenge both our assumptions and our attempt at their implementation. But unless the policy trade-offs that we have addressed in this Article are more candidly debated in legislative and judicial forums, the derivative action seems unlikely to survive as more than a nuisance to defendants and an occasional modest source of income for plaintiffs' attorneys.

\section{POSTSCRIPT}

As this Article goes to press, the Delaware Supreme Court has written the most important chapter in the still continuing saga of the Maldonado litigation. Reversing Maldonado II, the court upheld the basic power of a board, or a properly delegated committee thereof, to control corporate litigation and in principle to seek dismissal of even a meritorious action that is not in the corporation's best interest. ${ }^{343}$ Still, for the corporate bar this affirmation of orthodoxy is likely to seem a Pyrrhic victory. In sharp contrast to Auerbach $v$. Bennett, ${ }^{344}$ the decision (now restyled as Zapata Corp. v. Maldonado) expressly refused to accept the " 'business judgment' rationale" under which decisions to terminate derivative litigation were seen as but another aspect of the board's authority to manage the corporation. ${ }^{345}$ Instead, after finding "a sufficient risk in the realities of a situation like the one presented in this case" to make it unwilling to trust "the theory of business judgment," ${ }^{346}$ the court faced the problem squarely:

342. See Twentieth Century Funa Task Force on Criminal Sentencing, Fair and Certain Punishment (1976).

343. Zapata Corp. v. Maldonado, No. 113, 1980, slip op. at 12, 15-16 (Del. May 13, 1981). In essence, the decision upheld the legal power of the board to reject the suit, but subjected it to equitable limitations. This distinction between legal power and equitable limitation has a long history in Delaware corporate law. See, e.g., Singer v. Magnavox Co., 380 A.2d 969 (Del. 1977); Schnell v. Chris-Craft Indus., Inc., 285 A.2d 437 (Del. 1971).

344. 47 N.Y.2d 619, 393 N.E.2d 994, 419 N.Y.S.2d 920 (1979).

345. Zapata Corp. v. Maldonado, No. 113, 1980, slip op. at 22 (Del. May 13, 1981). The decision cited Maldonado $I$ as a decision that had incorrectly adopted this business judgment theory, thus suggesting that it should be reversed on appeal. Id. at 21 .

346. Id. at 22 . 
At the risk of stating the obvious, the problem is relatively simple. If, on the one hand, corporations can consistently wrest bona fide derivative actions away from well-meaning plaintiffs through the use of the committee mechanism, the derivative suit will lose much, if not all, of its generally-recognized effectiveness as an intracorporate means of policing boards of directors. If, on the other hand, corporations are unable to rid themselves of meritless or harmful litigation and strike suits, the derivative action, created to benefit the corporation, will produce the opposite, unintended result. ${ }^{3.7}$

Thus, seeing the fate of the derivative action as hanging in the balance, the court set out to find a "balancing point where bona fide stockholder power to bring corporate causes of action cannot be unfairly trampled on by the board of directors, but the corporation can rid itself of detrimental litigation." 348

Here, the candor of the decision is remarkable and potentially a turning point. Missing is the customary presumption that the board acts in good faith and in the best interests of all shareholders unless clearly proven otherwise. Instead, there is a frank recognition of the potential for structural bias in termination decisions-what the court aptly terms the possibility of "a "there but for the grace of God go I' empathy" on the part of the independent directors. ${ }^{39}$ To justify substantive judicial review, the court analogized the termination decision to judicial approval of a settlement-a context where the burden is traditionally on the proponent and where judicial discretion is clearly established. ${ }^{330}$ Although this analogy may amount to bootstrapping for a Delaware court (since Delaware has no general requirement of judicial approval of settlements in derivative actions ${ }^{35}$ ), it is apt, and the rules in these two functionally related areas clearly should be integrated. ${ }^{352}$

But if Zapata's diagnosis seems incisive, its prescription raises difficult problems about judicial competence. Ultimately, the court fashions a two-part test. First, the corporation seeking dismissal must establish the independence and good faith of the committee reaching the decision and the reasonableness of their investigative efforts. The burden on the corporation will apparently resemble the "intrinsic fairness" standard governing interested-director transactions. ${ }^{333}$

347. Id. at 20-21 (citations omitted).

348. Id. at 21 .

349. Id. at 23 .

350. Id. at 23-24. See also notes 309-11 and accompanying text supra.

351. As the court notes, judicial approval is required in Delaware when the directors are also settling defendants and thus are on both sides of the transaction. Zapata Corp. v. Maldonado, slip op. at 23-24. See Perrine v. Pennroad Corp., 47 A.2d 479, 486 (Del. 1946), cert. denied, 329 U.S. 808 (1947).

352. On policy grounds, it seems a perverse result to require greater procedural formality in the ease of a settlement, where the eorporation at least receives some recovery, than in the case of a termination decision, where it receives none.

353. Zapata Corp. v. Maldonado, slip op. at 27 n.I7. Auerbach would also permit some inquiry into these areas, but denies the court the power to "inquire as to which factors were considered by [the] committee or the relative weight accorded them. ..." Auerbach v. Bennet, 47 N.Y.2d 619, 633, 393 N.E.2d 994, 1002, 419 N.Y.S.2d 920, 928 (1979). 
Second, the chancery court in its discretion may then apply its. own "independent business judgment" in determining whether to accept the decision. ${ }^{354}$

This concept of a judicial business judgment is obviously founded upon a public-policy view of the derivative action, with which we are in agreement. Indeed, the Delaware Supreme Court instructs the chancery court to "give special consideration to matters of law and public policy in addition to the corporation's best interests," 355 thus recognizing that there can be a transcending importance to the concept of corporate accountability, over and above the narrow interests of a particular corporation in a given case.

But are courts in fact competent to exercise business judgment? ${ }^{356}$ The traditional view of judicial review has often stressed that its legitimacy rests on reasoned elaboration of principles capable of evenhanded application. In contrast, business judgments, as we have earlier stressed, tend to be intuitive, predictive, and constantly shifting in the criteria employed. A common law of business judgment cannot easily be built on such a foundation. We should be cautious here not to overstate: if forced to choose between the dogmatic assertion in Auerbach that courts can never review business judgments and the somewhat facile confidence in judicial competence in Zapata, we undoubtedly would prefer the latter, and the risk of harm seems slight. But, absent such a stark choice, the corollary to the chancery court's assertion, in Maldonado II, that "under our system of law, courts and not litigants should decide the merits of litigation," 357 is that boards, and not courts, are entitled to exercise business judgment. Our concern is not just for the formal constraints on judicial review. Rather, we suspect that courts, despite the new authority given them by Zapata, will continue to defer to the business judgment justifications that the board offers. Engrained traditions do not disappear overnight; rather, they persist in ways that have low visibility.

In this light, there are a number of uncertainties and problems surrounding the scope of the Zapata holding. First, it is unclear how much weight Delaware courts will place in the future on whether the plaintiff was obligated to make demand. A close reading of the decision suggests that plaintiffs who are required to make demand will bear the burden of proving that the board's rejection was wrongful, while, conversely, the corporation will have the procedural burden in those cases where demand was properly excused. ${ }^{358}$ Second, Zapata will

354. Zapata Corp. v. Maldonado, slip op. at 28.

355. Id. This suggestion that public policy considerations can outweigh the corporation's best interests is reinforced by other language in the opinion, which refers to the role of the derivative suit in "policing boards of directors." Id. at 20 . Both references suggest a deterrence rationale.

356. The concept of a judicial business judgment, though unorthodox to say the least, has an earlier history in Delaware corporate law. See Neponsit Investment Co. v. Abramson, 405 A.2d 97 , 100 (Del. 1979); Perrine v. Pennroad Corp.. 47 A.2d 479. 488 (Del. 1946). cert. denied. 329 U.S. 808 (1947).

357. 413 A.2d at 1263. In Zapata, the Delaware Supreme Court acknowledged its general agreement with this statement. Zapata Corp. v. Maldonado, slip op. at 28 n.18.

358. Plaintiff never made demand on the board in the Maldonado litigation, see Zapata Corp. v. Maldonado, slip op. at 2 , and the Delaware Supreme Court treats demand as properly excused on the facts of the case, given the involvement of the directors in the stock options at issue, id. at 14. The court makes clear, however, that where demand is required, "a board decision to cause a derivative suit to be dismissed as detrimental to the company, after demand has been made and 
apparently still permit a board heavily dominated by defendants to appoint a committee of three independent directors to reach a predictable decision to terminate. ${ }^{359}$ Finally, the Delaware Supreme Court's critical second step-i.e., the "independent business judgment" review - is entirely optional and discretionary with the individual chancery court judge. ${ }^{360}$ This would appear to mean that appellate review will be essentially unavailable if the lower court decides against such a review. If this second step is, as the Supreme Court said, the "essential key in striking the balance," ${ }^{361}$ it seems inconsistent to permit a lower court to disregard it.

These ambiguities suggest again the superiority of a legislative resolution and in particular of prophylactic rules. Rather than depend on judicial activism in an area where no trails are well marked and few definite standards exist, we believe it safer and more efficient to carve out the context of self-dealing transactions between the corporation and certain defined "controlling persons" from the scope of the board's power to terminate. This will not prohibit such transactions, but will ensure that the merits of the case can eventually be reached. To prefer this approach is not to criticize the Delaware Supreme Court for failing to adopt it judicially. The reach of courts in this area inevitably falls short of the legislature's. On its own terms, the Zapata decision deserves recognition as a serious effort at judicial statesmanship by the Delaware Supreme Court-but one that needs legislative codification and embroidery.

\section{APPENDIX}

Proposed Revision to Section 49 of the Model Business Corporation Act

Section 49. Shareholder's Derivative Action

(a) As used in this section:

(1) "Aggregate Director's Fees" shall mean with respect to any director the total of all salary, fees, and other compensation, including fees rcceived for attendance at board or committee meetings, received by such individual from the Corporation in respect of such office, less reasonable expenses actually incurred in connection with attendance at such meetings or the performance of other specifically delegated duties.

(2) "Annual Gross Income" shall mean an individual's gross income, exclusive of capital gains, as reported to the Internal Revenue Service or such

refused, will be respected unless it was wrongful." Id. at 12 . In a footnote, it adds that in the case of rejection after demand, "the board's decision falls under the 'business judgment' rule and will be respected if the requirements of the rule are met." Id. at 12 n.10. This statement is then clouded by the court's recognition, in the final sentence of the footnote, that "the two contexts can overlap in practice." Id. Nonetheless, read literally, the court's statement appears to mean that in a case where demand was required the chancery court would not be entitled to apply its own "independent business judgment." Although there is a logic to this distinction. we submit that such a drumutic difference in treatment is not warranted, and hence a legislative codification of the termination power that would subject all such decisions to some measure of substantive judicial review is preferable.

359. Id. at 18-20 (noting that the "interest taint of the board majority" is not "per se a legal bar to the delegation of the board's power to an independent committee").

360 . Id. at 27.

36I. Id. at 28 . 
higher amount as may be derivable from a recomputation of such person's federal tax liability as finally determined by such agency or a federal court.

(3) "Controlling Person" shall mean any person who possesses the ability to determine the principal policies or practices of the Corporation, whether by reason of stock ownership, managerial position, board membership, or otherwise. The chief executive officer of the Corporation shall be deemed to be a controlling person, but membership on the board of directors of the corporation shall not by itself cause a person to be considered a Controlling Person.

(4) "Corporation" shall include unincorporated associations, partnerships, and not-for-profit corporations and, unless the context otherwise requires, shall mean the corporation, partnership, or other business entity in whose name the derivative action is instituted.

(5) "Damage Ceiling" shall mean with respect to any individual such individual's highest Annual Gross Income during the five years immediately preceding the verdict in the derivative action.

(6) "Domestic Corporation" shall mean a Corporation incorporated under the laws of this state or a foreign corporation inade statutorily subject to the substantive corporate law of this state because of its contacts with this state.

(7) "Due Care Violation" shall mean a violation of the duty of due care owed by a corporate official to the Corporation or a substantially similar fiduciary breach by such an individual not involving self-dealing or the receipt of any improper personal benefit.

(8) "Equity Security" shall include (A) any share of stock, regardless of class, preference or other designation, issued by the Corporation, (B) warrants or options issued by the Corporation which are convertible into shares of its stock, and $(C)$ those debt securities of the Corporation that are classified under generally accepted accounting principles in effect at the time of the suit's commenceinent as "common stock equivalents," but such term shall exclude those debt securities not so classified.

(9) "Independent Director" shall mean a director elected by the shareholders who is not described by any of the following subparagraphs (A) through (E):

(A) any person who is, or who within five years preceding his appointinent to the board of directors has been, an officer or employee of the Corporation, any of its parents, subsidiaries, or other affiliates;

(B) any person who is related to any senior executive officer of the Corporation, any of its parents, subsidiaries, or other affiliates, by blood, inarriage, or adoption (excluding relationships more remote than first cousin);

(C) any person who has served as a lawyer, investment banker, commercial banker, or supplier to the Corporation, or any of its parents, subsidiaries, or other affiliates, and who has received, or whose firm or company (with which he is associated) has received, payments of a material amount to such recipient in the last three years, or to whom it is proposed that such payment will be made in the current or next year;

(D) any person who has a material pecuniary interest in the trans-

action; or 
(E) any person who has any other relationship to the Corporation which the court determines would impair that person's exercise of disinterested judgment. The fact that such person is a defendant in the lawsuit in question shall not disqualify that person from being deemed independent if the court affirmatively determines that the inclusion of such person as a defendant was without substantial merit or that the primary purpose of naming such person as a defendant was to prevent him from being deemed an independent director.

(10) "Person" shall include in addition to natural persons any corporation, partnership, business trust, joint stock association, or other business entity.

(11) "Qualified Owner" shall mean a holder of an Equity Security issued by the Corporation and includes, in addition to registered holders, (A) the holders of voting trust certificates issued with respect to any Equity Security and (B) any person entitled to a substantial beneficial interest in any trust or fund holding an Equity Security in the name of a nominee or fiduciary if it is actuarially possible to determine the value of such interest and such person's interest in the fund exceeds ten per cent; provided, however, that in the case of both (A) and (B) above if the governing trust instrument expressly denies the power to commence a derivative action to such beneficiary, then such person shall not be a Qualified Owner for purposes of this section.

(12) "Special Counsel" shall mean an individual attorney capable of disinterested judgment who has not participated in, or advised with respect to, the transactions or events under review and who is not described by any of subparagraphs (a)(9)(A) through (a)(9)(E) of this Section.

(b) An action may be brought in the right of a Corporation, domestic or foreign, to procure a judgment in its favor by a Qualified Owner. Upon judgment for the plaintiff, the court may award damages and/or grant any equitable relief it deems just and necessary in the circumstances, including a decree suspending or removing a corporate official or director from office.

(c) In any such action, the plaintiff must aver and prove that it is a Qualified Owner at the time of bringing the action and that either (1) it was such an owner at the time of the transaction of which it complains; or (2) its shares or interest therein devolved upon it by operation of law from a person who was such an owner at such time; or (3) it did not have actual knowledge of the transaction of which it complains at the time it acquired its shares or interest and the Corporation had not made sufficient disclosure in a public manner by such time to have given it constructive knowledge; or (4) there is a strong prima facie case in favor of the claim asserted on behalf of the Corporation and without such suit serious injustice will result. The complaint shall also allege with particularity the efforts made by the plaintiff to obtain the action it desires from the directors or comparable authority or the reasons why such a demand would be futile. The suit may not be maintained if the court finds the reasons so set forth to be inadequate or that the plaintiff cannot fairly and adequately represent the interests of the security holders similarly situated in enforcing the rights of the Corporation. No demand or request for action need be made upon security holders generally.

(d) Suit may be brought under this Section to recover any losses or damages suffered by any Corporation, domestic or foreign, in connection with a breach of 
a legal or equitable obligation to the Corporation or to recover any expenses incurred by the Corporation in connection with a violation of law by the Corporation. In computing the amount recoverable under this section, (1) the defendant shall be permitted to prove that the transaction resulted in a net benefit to the Corporation; provided, however, that the court may disregard any such benefit to the Corporation if the offset would frustrate a public policy of the state under this or any other provision of law, and (2) the plaintiff shall be permitted to prove that a transaction or policy resulted in intangible losses or damages to the Corporation if such losses or damages can be demonstrated by clear and convincing evidence. The court may direct that recovery shall be awarded to individual shareholders on a pro rata basis if it finds that a corporate recovery would result in unjust enrichment.

(e) An action under this Section may be dismissed on the grounds that the board of directors has determined that the action is contrary to the Corporation's best interests, or on substantially similar grounds, under the following circumstances and not otherwise:

(1) If the Corporation is a Domestic Corporation and the action asserts a breach of a fiduciary duty by a corporate official, employee, director, or Controlling Person, the court shall dismiss the action as it pertains to such defendants if the applicable conditions of subsection (f) below are satisfied;

(2) If the Corporation is not a Domestic Corporation, the court shall dismiss the action if the law of the Corporation's state of incorporation would accept such a defense on the facts of the case; provided, however, that the court shall not dismiss such an action if to do so would substantially frustrate a public policy of this state that is necessarily implicated by the board's decision;

(3) In all other cases, the court may dismiss the action unless the board's action appears clearly unreasonable or lacking in good faith.

(f) In the case of an action brought on behalf of a Domestic Corporation and asserting the breach of a fiduciary duty to such corporation, the court may dismiss such action against such corporate fiduciaries, and shall do so, if the court finds that the Corporation has established each of the following conditions:

(1) A majority of the board of directors consists of persons qualifying as Independent Directors, and the full plenary authority of the board of directors with respect to the litigation was delegated by the board to such directors;

(2) The Independent Directors conducted, or caused to be conducted, an adequate investigation into the underlying transaction or transactions and, to the extent that expert advice formed a basis for their decision, they relied upon the advice of Special Counsel and other experts independent of the Corporation who had not previously participated in or advised with respect to the transactions or matters under review;

(3) Dismissal of the action was approved by a vote of a majority of the Independent Directors without any other directors or defendants participating in the discussions or decisions;

(4) In so approving dismissal, the Independent Directors adopted a report (which may have been prepared by a special committee of the Independent Directors) that identifies a substantial business justification independent of the merits of the litigation, and in the court's judgment such justification (A) is not 
outweighed by the net probable recovery or other relief that the court finds is likely to result from the action, (B) does not frustrate any authoritatively established public policy, and $(C)$ is advanced in good faith; and

(5) The basic subject matter of the suit does not involve to a significant degree transactions or dealings, direct or indirect, between the Corporation, or a subsidiary thereof, and any Controlling Person of the corporation or any person controlling, under the control of, or under common control with, such Controlling Person.

Before reaching a decision to dismiss the action, the court shall permit the plaintiff a reasonable opportunity to obtain discovery and to contest the Corporation's position.

(g) If the action on behalf of the Corporation is successful, in whole or in part, or if a substantial benefit was caused or conferred by any plaintiff or other claimant as the result of the action, whether by judgment, compromise, settlement or otherwise, the court shall award such plaintiff or claimant reasonable expenses, including attorney's fees, but shall direct any plaintiff or claimant who has received any payment or other property as a result of the action in excess of such amount to account to the Corporation for the balance of any such proceeds so received. In determining the appropriate counsel fee to award to such a plaintiff or plaintiffs, the court may consider the size of the recovery received by the Corporation as a result of the action, but shall place primary emphasis on the following facts:

(1) the time and labor reasonably expended by each attorney;

(2) the difficulty of the case and the risk assumed by the attorney;

(3) the quality of the attorney's work;

(4) the degree to which the financial recovery is offset by any indemnification payments paid or to be paid the defendant;

(5) in a case involving nonpecuniary relief, the importance of the statutory policies protected or vindicated; and

(6) the effect of the allowance on the public interest and willingness of attorneys generally to accept similar cases.

(h) In any action brought under this Section in a court of this state, no bond or other security for expenses may be required by the court. The court may in its discretion award applicable costs, including reasonable attorney's fees, against a party, or against counsel, in the following circumstances:

(1) The court may award costs against plaintiffs or their counsel if it concludes upon final judgment for the defendants that the action was brought without reasonable cause;

(2) The court may award costs against any party or their counsel at any time if it finds with respect to such party or counsel that a motion, request for discovery, attempt to resist discovery, or appeal was made without reasonable cause and either materially protracted the litigation or constituted an abuse of the discovery process; or

(3) The court may award costs against the defendant or defendants if the expenses incurred by the Corporation in connection with the action, including the expenses awarded to a successful plaintiff, would otherwise exceed the monetary recovery received from the defendant or defendants. Such costs may 
be allocated among multiple defendants in such proportion as the court deems fair and equitable in view of their respective involvement and responsibility.

(i) An action authorized by this Section shall not be discontinued, compromised, or settled without approval by the court having jurisdiction of the action. If the court shall determine that the interests of the holders of Equity Securities or of any class thereof will be substantially affected by the discontinuance, compromise, or settlement, the court shall direct that notice, by publication or otherwise, be given to such holders whose interests will be so affected. If notice is so directed to be given, the court may determine which one or more of the parties to the action shall bear the expense of giving the notice, in such amount as the court determines and finds to be reasonable in the circumstances. The amount of such expense shall be awarded as special costs of the action and recoverable in the same manner as statutory taxable costs. Upon request, objecting holders shall be permitted a reasonable opportunity to present testimony and evidence, to obtain discovery, to cross-examine witnesses for the proponents of settlement, and to appeal a decision by the court approving a settlement.

(j) In evaluating the adequacy of a proposed settlement, the court shall give primary attention to the following factors:

(1) the size of the recovery and the value of any other relief in relation to the most probable recovery;

(2) the impact of further delay on the value of the most probable recovery;

(3) the extent of any corrective measures required by the settlement or undertaken as a result of the litigation and their adequacy in preventing possible future fiduciary breaches;

(4) the adequacy of the financial contribution paid by the settling defendants as a disincentive for future violations, both by them individually and by other corporate officials generally, and the extent to which such contribution will be reduced by any indemnification payments paid or to be paid by the Corporation; and

(5) the availability of other plaintiffs able effectively to prosecute the action, or a portion thereof.

The proponents of a settlement shall bear the burden of proving it to be in the best interests of the Corporation and its shareholders. All payment or payments made, or to be made, by the Corporation in respect of indemnification as a result of the action shall be disclosed in open court by the parties prior to judicial approval of the settlement and prior to any award of counsel fees pursuant to subsection $(\mathrm{g})$ hereof, and no subsequent payment shall be made which was not so disclosed at such time.

(k) If a natural person is adjudged liable in an action under this section and such liability is based exclusively on a Due Care Violation, then the financial liablity of such individual to the corporation shall not exceed the greater of (1) the highest Annual Gross Income of such person during the five calendar years preceding the date of the verdict, or (2) the Aggregate Director's Fees, if any, received by such person; provided, however, that if the court determines that such a ceiling would still result in the imposition of financial liability disproportionate to the blameworthiness of such individual, then the court may reduce 
such ceiling to a level not less than the lesser of (1) or (2) above. If the trier of fact was a jury, the court may require a special verdict to determine the basis of liability, and the burden shall be on such defendant to prove to the court that the damages awarded exceeded such ceiling. 